\title{
San Isidoro de León. Construcción y reconstrucción de una basílica románica
}

\section{San Isidoro de León. Construction and reconstruction of a romanesque basilica}

\author{
M.a Á. Utrero Agudo \\ Investigadora contratada Ramón y Cajal, Instituto de Historia, CSIC. \\ e-mail: mariaangeles.utrero@cchs.csic.es \\ J. I. Murillo Fragero \\ Arqueólogo, Urbe pro Orbe Patrimonio Cultural. \\ e-mail: jimurillo@urbeproorbe.com
}

\section{RESUMEN}

Este artículo presenta los principales resultados obtenidos en el análisis arqueológico de los alzados de la basílica de San Isidoro de León, centrándose principalmente en aquellos que afectan a su concepción y evolución durante los siglos XI y XII. La extensa investigación que se ha ocupado de este edificio se caracteriza por un prolongado debate en torno a sus fases constructivas y al mecenazgo de la monarquía leonesa. El presente análisis constata una basílica originaria construida a mediados del siglo XI. Esta construcción será sustituida por otra de mayor escala y con transepto, la cual sufre una temprana ruina que afectará principalmente a la mitad occidental del aula. Tanto las bóvedas de ladrillo de esa zona como la Puerta del Cordero pertenecen a la obra de restauración de mediados del siglo XII.

Palabras clave: Estratigrafía, arquitectura medieval, Puerta del Cordero, Puerta del Perdón, Camino de Santiago, Marcas de cantero, siglos XI y XII.

\begin{abstract}
This paper shows the main results obtained thanks to the archaeological analysis of the standing walls of the basilica of San Isidoro de León, paying special attention to those affecting its conception and evolution during the $11^{\text {th }}$ and $12^{\text {th }}$ centuries. The research devoted to this building is characterised by a long debate regarding its buildings phases and the patronage of the monarchy of Leon. The analysis records an original basilica built in the mid $11^{\text {th }}$ century. This construction is substituted by another one bigger in scale and with a transept, which suffers an immediate ruin that will mainly destroy the occidental area of the hall. The brick vaults and the Lamb's Door sited in this part of the building belong thus to the restoration works carried out in the mid $12^{\text {th }}$ century.
\end{abstract}

Keywords: Stratigraphy, Medieval architecture, Puerta del Cordero, Puerta del Perdón, St James' route, Masons' marks, $11^{\text {th }}$ and $12^{\text {th }}$ centuries.

Recibido: 8 abril 2014. Aceptado: 19 julio 2014.

Cómo citar este artículo / Citation

Utrero Agudo, M.a Á. y Murillo Fragero, J. I.: "San Isidoro de León. Construcción y reconstrucción de una basílica románica", Arqueología de la Arquitectura, 11: e014. doi: http://dx.doi.org/10.3989/arq.arqt.2014.011

Copyright

(c) 2014 CSIC. Este es un artículo de acceso abierto distribuido bajo los términos de la licencia Creative Commons Attribution-Non Commercial (by-nc) Spain 3.0. 
"... if the construct of Romanesque has only ever existed in the culture of scholarship, as I argue here is the case, then the only way to deal with it is through the portal of epistemology, and the only such portal that one can pass through confidently is the portal of one's own discipline", O’Keeffe (2007: p. 9) ${ }^{1}$

Acercarse al estudio de la Real Colegiata de San Isidoro de León supone entrar en uno de los conjuntos eclesiásticos más visitados por peregrinos, estudiosos e investigadores. Intentar sintetizar su historiografía equivale a recorrer, sin ánimo de exagerar, toda la bibliografía del Románico europeo. Su relevancia histórica y artística como basílica vinculada al poder regio y estación obligada del Camino de Santiago hace de esta iglesia una de las protagonistas asiduas de la investigación de la historia del arte medieval tanto en España como en la Europa occidental. Su historia ha sido, sin embargo, principalmente dictada por la secuencia monárquica y las referencias escritas (documentales y epigráficas), y apuntada de manera complementaria con la materialidad del edificio, dando lugar a distintas propuestas con puntos comunes. Todas estas hipótesis coinciden en reconocer, primero, una obra de mediados del siglo XI en el lugar a partir de la interpretación de las fuentes escritas y de los vestigios hallados a inicios del siglo XX en el subsuelo del edificio, puestos a su vez en relación con los alzados del ángulo noroeste de la basílica; y segundo, en identificar hasta cuatro obras diferentes en la construcción de la gran iglesia románica consagrada en 1149.

El análisis que aquí se expone, realizado únicamente en la basílica, constata una secuencia inédita que incorpora nuevos episodios a ese relato histórico ${ }^{2}$. Un edificio, de posible origen romano y de función indeterminada, es amortizado por la construcción de otro nuevo a mediados del siglo XI. Este será a su vez reutilizado a lo largo de la segunda mitad del siglo XI e inicios del XII en la ejecución de un nuevo y ambicioso proyecto que concibe una gran basílica abovedada con transepto. Dimensiones desproporcionadas y cargas excesivas se

\footnotetext{
“... si la construcción del Románico ha existido siempre solo en la cultura de la academia, como argumento aquí, entonces la única manera de tratarlo es a través de la puerta de la epistemología, y la única puerta que uno puede pasar con confianza es la de su propia disciplina", traducción de los autores.

2 Análisis presentado de manera completa en Utrero, M. Á. y Murillo, J. I. 2010: Basílica de la Real Colegiata de San Isidoro de León. Lectura de paramentos, 2008. Madrid: informe manuscrito, Servicio de Restauración de la Junta de Castilla y León.
}

alían para arruinar esta obra, la cual es sin embargo reconstruida en un breve periodo de tiempo y, posiblemente de forma apresurada, finalizada en la segunda mitad del siglo XII. De este modo, construcción, ruina y reconstrucción de San Isidoro se suceden en el tiempo, condicionando su forma en época románica y su estado de conservación actual.

\section{SAN ISIDORO DE LEÓN COMO SUJETO DE ESTUDIO}

Las ideas de cambio y de sucesión de varios proyectos constructivos han perseguido a San Isidoro de León desde los inicios de su investigación allá a mediados del siglo XIX. Así lo expresaban Quadrado y Parcerisa (1855: p. 338) al observar cómo "venerables lapidas concretan y fijan a cada paso el objeto y la fecha de su erección, de sus trasformaciones, de sus aumentos y vicisitudes". Es por ello que la revisión de las etapas y promotores propuestos a partir de la puesta en común de las fuentes históricas y de la observación del edificio permite dibujar el marco histórico e historiográfico en el que se inscribe San Isidoro y su análisis, así como identificar las principales cuestiones y problemáticas que encierra (Fig. $1^{3}$ ).

1. Los precedentes: San Juan Bautista y San Pelayo. La historia de San Isidoro comenzaría con la construcción de una o varias iglesias intramuros en el ángulo noroeste del recinto romano de la ciudad de León. Se supone, por un lado, la presencia de una iglesia dedicada a San Pelayo, cuya advocación fue cambiada a San Juan por Alfonso V (De Morales, Florez 1765: p. 41); o, por el contrario, de una primera iglesia consagrada a San Juan, construida por Ordoño I (821-866), a la cual siguió posteriormente otra dedicada a San Pelayo, fundada por Sancho I el Craso (956-58 y 960-66), pasando así el monasterio a tener una doble advocación (Risco 1786: p. 20; Gómez Moreno 1925: p. 179; Pérez Llamazares 1927: p. 9 y Robles 2007: p. 32). La iglesia de San Juan Bautista sería, en principio, la precedente de San Isidoro.

A excepción de Mélida (1910: p. 151), quien relacionó estas iglesias con las estructuras halladas en excavación y con los correspondientes alzados en los muros oeste y norte del aula, la mayoría de los investigadores

Esta tabla recoge las principales propuestas por orden cronológico, trayendo a texto solo aquellas singulares por su significado. Se intenta así exponer de la manera más completa posible la historiografía del edificio sin prolongarla en exceso. 


\begin{tabular}{|c|c|c|c|c|c|c|c|}
\hline & Siglo $\mathrm{X}$ & $\begin{array}{l}\text { Alfonso V } \\
(999-1027)\end{array}$ & $\begin{array}{c}\text { Fernando I (1037-65) y } \\
\text { Sancha }(\dagger 1067)\end{array}$ & $\begin{array}{c}\text { Infanta Urraca } \\
(1072-\dagger 1101)\end{array}$ & $\begin{array}{c}\text { Reina Urraca } \\
(1109-1126)\end{array}$ & $\begin{array}{l}\text { Alfonso VII } \\
(1126-1157)\end{array}$ & $\begin{array}{l}\text { Fernando II } \\
(1157-1188)\end{array}$ \\
\hline $\begin{array}{l}\text { A. de Morales } \\
\text { ca. 1582 } \\
\text { (Florez 1765) } \\
\end{array}$ & $\begin{array}{l}\text { Sancho I }(960-66) \text {, } \\
\text { monasterio de San } \\
\text { Pelayo }\end{array}$ & $\begin{array}{l}\text { Reedifica monasterio, } \\
\text { advocación a San } \\
\text { Juan }\end{array}$ & $\begin{array}{l}\text { Amplia anterior, iglesia } \\
\text { advocación a San Isidoro. } \\
\text { Panteón }\end{array}$ & & & & \\
\hline $\begin{array}{c}\text { Quadrado y } \\
\text { Parcerisa } \\
1855 \\
\end{array}$ & $\begin{array}{l}966 \text { San Juan } \\
\text { Bautista }\end{array}$ & $\begin{array}{l}\text { Reedificada en lodo y } \\
\text { ladrillo }\end{array}$ & $\begin{array}{l}1063 \text { Panteón e iglesia } \\
\text { primitiva }\end{array}$ & & & $\begin{array}{l}1149 \text { lápida de } \\
\text { consagración en } \\
\text { brazo } \mathrm{S}\end{array}$ & \\
\hline $\begin{array}{l}\text { Lampérez } \\
\text { 1908-09 }\end{array}$ & 966 San Juan & $\begin{array}{l}\text { Reforma de barro y } \\
\text { ladrillo }\end{array}$ & $\begin{array}{l}1063 \text { Reedificada: ábsides, } \\
\text { transepto y puerta del } \\
\text { Perdón }\end{array}$ & Ampliación & & $\begin{array}{l}1149 \text { consagración: } \\
\text { aula y puerta del } \\
\text { Cordero }\end{array}$ & \\
\hline $\begin{array}{l}\text { Mélida } \\
1910\end{array}$ & $\begin{array}{l}966 \text { San Juan. } \\
\text { Estructuras } \\
\text { excavadas y narthex }\end{array}$ & $\begin{array}{l}\text { Reforma o reparación } \\
\text { de barro y ladrillo }\end{array}$ & $\begin{array}{l}\text { 1063 Reconstrucción: } \\
\text { ábsides y transepto. } \\
\text { Dedicación a San Isidoro }\end{array}$ & Ampliación (sin especificar) & & $\begin{array}{l}1149 \text { Nueva } \\
\text { consagración: aula }\end{array}$ & \\
\hline $\begin{array}{c}\text { Díaz-Jiménez } \\
1917\end{array}$ & $\begin{array}{l}\text { 966, Sancho el } \\
\text { Craso. San Pelayo }\end{array}$ & $\begin{array}{l}1020 \text { Reforma de } \\
\text { barro y ladrillo San } \\
\text { Juan. Cimientos del } \\
\text { panteón }\end{array}$ & $\begin{array}{l}\text { Reforma de la anterior: } \\
\text { cabecera, transepto y } \\
\text { primeros tramos aula }\end{array}$ & $\begin{array}{l}\text { Prolongación desde puerta } S \text { hasta } \\
\text { los pies }\end{array}$ & & $\begin{array}{l}\text { Consagración obra } \\
\text { románica: obra de la } \\
\text { nave central }\end{array}$ & \\
\hline $\begin{array}{l}\text { Gómez } \\
\text { Moreno } \\
1925\end{array}$ & $\begin{array}{l}966 \text { Iglesia de } \\
\text { Ordoño I (821-66). } \\
\text { Destruido por } \\
\text { Almanzor. Sancho I } \\
\text { (960-66), } \\
\text { monasterio de San } \\
\text { Pelayo al lado } \\
\end{array}$ & $\begin{array}{l}\text { Reparación de barro } \\
\text { y ladrillo }\end{array}$ & $\begin{array}{l}1063 \text { Muros N y O, } \\
\text { panteón como nártex } \\
\text { (tribuna modificada) } \\
\text { Terminada por Sancha } \\
\text { viuda }\end{array}$ & $\begin{array}{l}\text { Ábsides, muros del transepto, dos } \\
\text { primeros tramos de las naves y } \\
\text { portada } S \text { transepto }\end{array}$ & $\begin{array}{l}\text { Inscripción } 1124 \\
\text { prueba existencia } \\
\text { ábside N (tal vez } \\
\text { epitafio) }\end{array}$ & $\begin{array}{l}1149 \text { Cuerpos altos } \\
\text { del crucero, nave } \\
\text { central, tribuna y } \\
\text { torre. Palacio. }\end{array}$ & $\begin{array}{l}\text { Pinturas de muros y } \\
\text { bóvedas del panteón }\end{array}$ \\
\hline $\begin{array}{c}\text { Pérez } \\
\text { Llamazares } \\
1927\end{array}$ & $\begin{array}{l}\text { Sancho I, } \\
\text { monasterio de San } \\
\text { Pelayo. Destruido } \\
\text { por Almanzor, } \\
\text { previo al } 990\end{array}$ & $\begin{array}{l}\text { Funda iglesia S. } \\
\text { Martino } \\
\text { (cementerio), al O de } \\
\text { S. Pelayo, restaurada: } \\
\text { S. Juan doc } 1028 \\
\text { como S. Pelayo y S. } \\
\text { Juan. Obra en ladrillo } \\
\end{array}$ & $\begin{array}{l}\text { Doc 1043, San Juan y San } \\
\text { Pelayo. Nueva iglesia y } \\
\text { cementerio en piedra de } \\
\text { San Juan y San Pelayo. } \\
\text { Actual iglesia, sin } \\
\text { transepto, y panteón y sus } \\
\text { pinturas }\end{array}$ & $\begin{array}{l}\text { Ampliación: cabecera y transepto. } \\
\text { Hallazgo de los cimientos de los } \\
\text { primitivos ábsides semicirculares }\end{array}$ & & & \\
\hline $\begin{array}{l}\text { Gómez } \\
\text { Moreno } \\
1934\end{array}$ & $\begin{array}{l}966 \text { San Juan y San } \\
\text { Pelayo. Destruido } \\
\text { por Almanzor }\end{array}$ & $\begin{array}{l}\text { Reedificada en tapial } \\
\text { y ladrillo }\end{array}$ & $\begin{array}{l}\text { 1054-63, terminada por } \\
\text { Sancha entre 1066-67. } \\
\text { Muros N y O y estructuras } \\
\text { excavadas }\end{array}$ & $\begin{array}{l}\text { Transepto como cambio de } \\
\text { proyecto de la obra en marcha. } \\
\text { Derribo de la iglesia vieja, } \\
\text { terminación O }\end{array}$ & & Dos tramos O & \\
\hline $\begin{array}{c}\text { Camps } \\
\text { Cazorla } 1935\end{array}$ & $\begin{array}{l}\text { San Juan y San } \\
\text { Pelayo. Destruido } \\
\text { por Almanzor }\end{array}$ & $\begin{array}{l}\text { Reedificación de } \\
\text { tapial y ladrillo }\end{array}$ & $\begin{array}{l}\text { 1054-63, terminada por } \\
\text { Sancha viuda entre } 1066 \text { y } \\
1067 . \text { Muros N y O y } \\
\text { estructuras excavadas }\end{array}$ & $\begin{array}{l}\text { Inicia obra } 1090-95.1^{\circ}: \text { muros y } \\
\text { pilares. } 2^{\circ} \text { : crucero, cabecera, } \\
\text { bóvedas laterales. } 3^{\circ} \text { : derribo de } \\
\text { antigua iglesia, empalme con } \\
\text { nuevas naves con contrafuertes, } \\
\text { puerta S (T. Cordero) y O }\end{array}$ & & & \\
\hline $\begin{array}{c}\text { Muir } \\
\text { Whitehill } \\
1939\end{array}$ & $\begin{array}{l}966 \text { iglesia } \\
\text { Destruida por } \\
\text { Almanzor }\end{array}$ & $\begin{array}{l}1020 \text { Reedificada de } \\
\text { barro y ladrillo }\end{array}$ & $\begin{array}{l}1063 \text { Consagración nueva } \\
\text { por cambio de dedicación. } \\
\text { Muros N y O y panteón }\end{array}$ & $\begin{array}{l}\text { Cabecera, muros estrechos y } \\
\text { cubierta de madera. Cambio } \\
\text { robustece muros mitad O }\end{array}$ & & $\begin{array}{l}1149 \text { finaliza obra } \\
\text { iniciada por Urraca. } \\
\text { Puerta del XII, pero } \\
\text { tallas anteriores }\end{array}$ & $\begin{array}{l}\text { Pinturas del XII, } \\
\text { modificación tribuna }\end{array}$ \\
\hline $\begin{array}{c}\text { Williams } \\
1973\end{array}$ & & & $\begin{array}{l}\text { Sustituye iglesia de } \\
\text { Alfonso V por una de } \\
\text { piedra. Muros } \mathrm{Ny} \mathrm{O}\end{array}$ & $\begin{array}{l}\text { Finales XI, ampliación: panteón, } \\
\text { galería N, tribuna y parte baja de } \\
\text { la torre }\end{array}$ & $\begin{array}{l}1124 \text { inscripción } \\
\text { en cabecera }\end{array}$ & $\begin{array}{l}\text { Pinturas panteón pre } \\
1149 \text {, consagración } \\
\text { basílica }\end{array}$ & \\
\hline Caldwell 1986 & & & $\begin{array}{l}\text { Muros } \mathrm{N} \text { y } \mathrm{O} \text { y adicción } \\
\text { del panteón }\end{array}$ & $\begin{array}{l}\text { 1070, inicio basílica de } 3 \text { naves, } \\
\text { ábsides semicirculares. Introduce } \\
\text { transepto. } 1090 \text { Puerta Cordero }\end{array}$ & & & \\
\hline Bango 1992 & $\begin{array}{l}\text { 966 Iglesia de San } \\
\text { Juan Bautista y San } \\
\text { Pelayo }\end{array}$ & $\begin{array}{l}\text { Reedificación de } \\
\text { tapial y ladrillo, } \\
\text { panteón y monasterio }\end{array}$ & Panteón de piedra & & & & Tribuna románica \\
\hline $\begin{array}{l}\text { Fernández } \\
\text { González } \\
1992\end{array}$ & $\begin{array}{l}\text { Sancho I (956-58 y } \\
\text { 960-66), } \\
\text { Monasterio San } \\
\text { Pelayo. Destruido } \\
\text { por Almanzor }\end{array}$ & $\begin{array}{l}\text { Iglesia de San Juan } \\
\text { en ladrillo y barro }\end{array}$ & $\begin{array}{l}\text { Nuevo San Juan en piedra, } \\
\text { muros N y O }\end{array}$ & 1080 Panteón & $\begin{array}{l}\text { Tímpano del } \\
\text { Cordero }\end{array}$ & & \\
\hline $\begin{array}{c}\text { Williams } \\
1993 \\
\end{array}$ & & & 1063 dedicación & $\begin{array}{l}1080 \text { Panteón. Frescos pre } 1109 \\
(\uparrow \text { Alfonso VI) }\end{array}$ & Transepto & $\begin{array}{l}1149 \text { finaliza la } \\
\text { basílica }\end{array}$ & \\
\hline Martin 2006 & $\begin{array}{l}\text { Monasterio doble } \\
\text { San Pelayo (al N, } \\
\text { en pie en 1144) y } \\
\text { San Juan (actual S. } \\
\text { Isidoro) }\end{array}$ & $\begin{array}{l}1013 \text { Primera } \\
\text { mención documental } \\
\text { a San Pelayo }\end{array}$ & 1055 Muros N y O & $\begin{array}{l}\text { 1065. Placa tímpano panteón. } \\
1080 \text { Palacio O, incluye panteón. } \\
1090 \text { Inicia iglesia desde E, tres } \\
\text { ábsides, sin transepto y cubierta } \\
\text { de madera; Puerta del Cordero } \\
\text { completa en } 1101 \text {. Hace } 4 \text { tramos }\end{array}$ & $\begin{array}{l}\text { Ca. } 1109 \text { pinturas } \\
\text { panteón } \\
1110-1124 \text { nuevo } \\
\text { transepto destruye } \\
\text { E }\end{array}$ & & \\
\hline Boto 2007 & $\begin{array}{l}966 \text { San Juan } \\
\text { Bautista }\end{array}$ & Reedificación & $\begin{array}{l}\text { Muros N y O, estructuras } \\
\text { excavadas, tres ábsides } \\
\text { semicirculares }\end{array}$ & Panteón & $\begin{array}{l}1100-10 \text { Iglesia } \\
\text { basilical sin } \\
\text { transepto } \\
1120-45 \text { transepto, } \\
\text { cabecera y dos } \\
\text { tramos orientales } \\
\end{array}$ & $\begin{array}{l}1120-45 \text { Transepto, } \\
\text { cabecera y dos } \\
\text { tramos orientales }\end{array}$ & \\
\hline
\end{tabular}

Fig. 1. Síntesis de las principales propuestas evolutivas sobre San Isidoro de León

aceptan la ausencia de cualquier evidencia material atribuible a ellas, quedando por tanto registradas solamente en los documentos escritos. La consideración de Almanzor como su destructor a finales del siglo $\mathrm{X}$, como se cita en el epitafio de Alfonso V, reproducido por Risco (1786: p. 29), justificaría este hecho.

2. Obra del rey Alfonso V (999-1027). En el citado epitafio de Alfonso $\mathrm{V}$ reza que el rey hizo la iglesia de 
barro y ladrillo: "Et fecit ecclesiam hanc de luto et latere". Esta inscripción plantea sin embargo varios problemas. Primero, el verdadero alcance de la obra de Alfonso V, la cual pudo ser nueva o, por el contrario, reformar una previa. Segundo, la pieza en sí misma, la cual parece haber sido tallada dos siglos después, a inicios del siglo XIII, momento en el que se asistiría a un intento de recalcar el papel de San Isidoro como lugar de enterramiento regio desde el siglo X (Suárez González 2003: p. 410 y Sánchez Ameijeiras 2005: pp. 506-508). Lo mismo parece suceder con el epitafio de Fernando I (1037-1065), pudiendo responder en ambos casos a un "topos" literario (Martin 2006: p. 48). Finalmente, la fecha de la obra, ausente en el epígrafe, y que se sitúa entre los años 1020 y 1027, cuando fallece Alfonso V.

Por lo tanto, esta obra tampoco se ha identificado en el edificio actual ni en los restos hallados en excavación, quedando, de nuevo, únicamente testimoniada en la epigrafía. La referencia a una obra de barro y ladrillo es además llamativa, por lo que apoyamos la idea de que sea un recurso literario que pretende subrayar tres siglos después la antigüedad del lugar ${ }^{4}$. Solamente Boto (2009) ha propuesto su identificación con los cimientos exhumados a inicios del siglo XX en el ángulo noroeste de la basílica, cuya potencia demostraría que no fueron concebidos para una iglesia de barro. En su opinión, su factura "asturiana", con una cabecera triple recta y escalonada, le haría además más propia de este momento a caballo entre los siglos X y XI.

3. Obra de los monarcas Fernando I (1037-1065) y Sancha (m. 1067). La inscripción, durante un tiempo situada en el claustro ${ }^{5}$ y trasladada a su posición actual,

\footnotetext{
4 Como Martin hace notar (2006: pp. 48-49, n. 55), una fórmula similar se repite en la Crónica de Sampiro (versión de los siglos X-XI) para explicar la construcción de la primera iglesia de piedra y barro sobre la tumba del apóstol en Santiago de Compostela por parte del rey Alfonso II y su sustitución por una mayor completamente en piedra en tiempos de Alfonso III (872). Al respecto, ver también Plötz (1982: p. 115).

5 Transcripción de Pérez Llamazares (1927: p. 358): "Hanc quam cernis aulam sci ioannis baptistae olim fuit lutea quam nuper excellentissimus ferdinandus rex et sancia regina aedificaverunt lapideam. Tunc ab urbe hispali adduxerunt ibi corpus sci ysidori archiepiscopi. Dedicatione templi huius die duodecimo Kal. ianuarii era MCI, Deinde in era MCIII sexto kal. maii adduxerunt ibi de urbe avila corpus sci viventii fatris sabinae christestisque. Ipsius anno praefatus sex revertens de hostes ab urbe valencia hinc ibi die sabbati et obiit die tertia feria sexta kal. ianuarii era MCIII. Sancia regina deo dicata peregit". Pérez Llamazares (1927: p. 359) menciona que, según el prior Durón (s. XVI), entonces el sitio de la lápida era "uno de los pilares del panteón que miran al claustro, y al presente se halla en el brazo norte del crucero, en el interior del templo: ahora bien, hasta el siglo XVI esta lápida estuvo a la puerta del templo, ofreciendo a todos los fieles la historia del mismo".
}

seguramente la original ${ }^{6}$, en los años 80 del siglo $\mathrm{XX}$, da fe de la consagración del templo a San Isidoro de Sevilla, después de haber traído sus reliquias de dicha ciudad, el 21 de Diciembre del año 1063 (Era 1101) por los monarcas Fernando I y Sancha. La obra se realizaría en piedra ("aedificaverunt lapideam"). Informa además de que dos años después, el 10 de marzo de 1065, antes de su fallecimiento, el rey trajo el cuerpo del mártir San Vicente de Ávila. La última parte de la inscripción se referiría a la reina Sancha ("Sancia regina deo dicata peregit"). Según Durliat (1990: p. 185), esta referencia aludiría a que en su tiempo, ya que sobrevivió dos años a su marido, se concluiría el templo. Por otro lado, la lauda sepulcral de Fernando I, hoy perdida, pero copiada también por Risco (1792: pp. 149-150), menciona que el monarca "fecit Ecclesiam hanc lapideam, quae olim fuerat lutea". Como hemos indicado, esta pieza pudo ser coetánea del siglo XI o posterior, ya del siglo XIII.

A excepción de Díaz-Jiménez (1917: p. 97) y Lampérez (1908-09: p. 461), quienes atribuyen a este momento del segundo tercio del siglo XI la cabecera de la iglesia, el transepto y los primeros tramos occidentales del aula, casi todos los autores consideran el muro oeste y norte y los hallazgos de los cimientos de un edificio, cuya alineación se correspondería con las huellas de los alzados, como la obra de Fernando I y Sancha. Las propuestas difieren en lo que atañe a la existencia de un posible pórtico meridional (Díaz-Jiménez 1917: pp. 93-94 y Williams 1973: p. 171, n. 5 y p.173), por un lado, y a la secuencia del panteón, considerado como original o posterior, concretamente de la infanta Urraca, por otro. Entre aquellos que aceptan el panteón como coetáneo a la obra de estos monarcas, unos optan por una función inicial como tal (Quadrado y Parcerisa 1855; Muir Whitehill 1939: p. 147; Caldwell 1986: p. 21; Enríquez de Salamanca 1990: p. 60; Bango 1992: p. 104, Fernández González 2009 y Seehausen 2009) y otros por el de narthex transformado luego en panteón con las consecuentes reformas arquitectónicas (Mélida 1910: p. 151, aunque original y previo al 966; Gómez Moreno 1925: p. 182 y 1934: p. 105; Viñayo 1964: p. 107 y 1978: p. 228, conversión por el mismo Fernando I).

4. Obras en el último cuarto del siglo XI y a lo largo del siglo XII. Este periodo es testigo de una sucesión de monarcas y obras. La infanta Doña Urraca (10721101) parece asumir el protagonismo constructor de sus

\footnotetext{
6 Como han indicado Pérez de Llamazares (1927: p. 359) y Martin (2006: pp. 46-47). Williams (1993: pp. 171-172) opina que fue extraída de la iglesia de Fernando I y Sancha y traída aquí cuando la infanta Urraca añade el panteón.
} 
progenitores Fernando I y Sancha y, según reza en su inscripción sepulcral copiada por Risco (1792: p. 150), habría ampliado la iglesia de su padre: "haec amplificavit ecclesiam istam”. Pero ¿qué amplió y cómo?

Díaz-Jiménez (1917: p. 98) propone que prolonga la basílica desde la puerta principal sur hacia Occidente. Gómez Moreno (1925: p. 186), por el contrario, atribuye a la infanta la cabecera, el transepto y los dos primeros tramos orientales del aula, y Camps (1935: pp. 76-77), la edificación en tres fases de toda la iglesia. Pérez Llamazares (1927: pp. 361-362), por su parte, dice haber visto los cimientos de los ábsides semicirculares que se unían con los últimos pilares orientales conservados y que correspondían a las naves laterales, atribuyendo por ello a la infanta la cabecera y el transepto. La Puerta del Cordero entra de pleno en esta secuencia, siendo adscrita mayoritariamente también a la infanta (Moralejo 1977, ca. 1100; Caldwell 1986: p. 21, ca. 1090; Enríquez de Salamanca 1990: p. 53; Williams 2003: p. 179, ca. 1100; Martin 2006, ca. 1101; Prado-Vilar 2009, ca. 1101; Müller-Reissmann 2009: p. 212, ca. 1080; otras opiniones en Fig. 1). Pero esta ampliación también pudo materializarse en la obra del panteón, siendo la infanta Urraca, y no Fernando I y Sancha, su promotora (Williams 1973: pp. 180-183; Yarza 1979: p. 191; Moralejo 1985: p. 411; Fernández González 1992; Williams 1993: p. 179 y 1997: p. 29, ca. 1080-90; Walker 1998: p. 120 y 2000, también le atribuye las pinturas; Martin 2005 y Prado-Vilar 2009: p. 203, ca. 1080).

La idea de una posible iglesia con cubiertas de madera es apuntada por Muir Whitehill (1939: p. 152) y desarrollada posteriormente por Viñayo (2002: p. 556) que, de modo similar a Camps (1935: p. 76), adjudica la iglesia a la infanta. La obra habría comenzado por la cabecera y al pretender conservar los muros norte y oeste de la obra de Fernando I y Sancha se estrechan necesariamente las naves laterales y "se paró la obra a la altura del arranque de las ventanas de la nave mayor". En la misma línea, Martin (2005: p. 388) propone que el proyecto de la infanta, iniciado hacia el año 1090, contempló una iglesia cubierta en madera, construida desde el este, con tres ábsides y sin transepto, llegando a completar cuatro tramos.

$\mathrm{Su}$ hermano Alfonso VI (1065-1109) ha pasado desapercibido (ausente en Fig. 1), tal vez por suponerse ocupado en el comienzo de las obras de las catedrales de Burgos y de Santiago de Compostela (1075 en adelante), así como en potenciar la ciudad de Sahagún con la construcción de un nuevo conjunto palatino con su correspondiente panteón real (Prado-Vilar 2009: p. 203). Durliat (1990: p. 186) considera que, desde 1072, una vez desaparecido de la escena su hermano Sancho de Castilla, enfrentado a Alfonso VI en una lucha dinástica por el poder, tendría lugar el inicio de la obra románica de San Isidoro. En el año 1110 las infantas Urraca y Elvira, hijas de Alfonso VI, realizaron una donación para unas obras (" $a d$ laborem"), lo que indicaría que estos trabajos estarían en marcha, continuando un proyecto en ejecución.

Lo mismo ha ocurrido con la reina Urraca (11091126), a la que únicamente la presencia de una inscripción con fecha 1124 en el paramento exterior del ábside norte le ha otorgado algún protagonismo. Martin (2005 y 2006), siguiendo la hipótesis de Williams (1993: p. 173), quien ya le atribuye la construcción del transepto de la iglesia, subraya el papel patrocinador de la reina Urraca (Martin 2008a) y la apertura de una iglesia, en principio vinculada al círculo real y monástico, al peregrinaje (Martin 2008b), siendo el transepto el reflejo arquitectónico de ambos fenómenos ${ }^{7}$. Entre 1110 y 1124 tendrían lugar la destrucción del tramo oriental de la iglesia y la introducción del nuevo transepto y de la nueva cabecera, la cual reutilizaría elementos decorativos de la primera. La Puerta del Perdón, cuya factura contextualiza a inicios del siglo XII (Martin 2003), y las pinturas del panteón serían de este mismo momento.

En esta misma línea, Poza (2003: p. 16) habla de un cambio de proyecto en marcha que implica la introducción del transepto. No establece dos momentos, como por el contrario hacen Martin o Boto (2007: pp. 76-83), quien supone la construcción de una primera iglesia sin transepto, ampliada en el periodo 1120-1145, a caballo entre los reinados de Urraca y Alfonso VII, con la construcción de los dos tramos orientales del aula. Estas propuestas se basan en la presencia de ciertas anomalías, como las juntas de obra en los muros del aula junto al transepto, un capitel picado en la arquería sur o la estrechez de los muros.

Observamos pues cómo el transepto ha pasado de manos de la infanta Urraca (1072-1101) a las de la reina Urraca (1109-1126), planteamiento en el que subyace la defensa de las etapas concluidas a partir de los documentos y que apunta al transepto y a su relación con el aula como una de las zonas cruciales para comprender la secuencia de San Isidoro.

El peregrinaje como causa de la introducción del transepto es también argumento para Caldwell (1986: p. 21), quien lo atribuye sin embargo a la infanta Urraca, no a la reina. 
La basílica sería consagrada en 1149, bajo el reinado y patrocinio de Alfonso VII (1126-1157). Risco (1786: p. 207) retoma el relato de Lucas de Tuy (m. 1249), canónigo de San Isidoro (1221-1239), quien se refiere a la lápida de consagración de ese año: "Conservase la memoria de esta consagración en una lapida que está encajada à el sitio que hoy ocupa el altar dedicado à N. P. S. Agustin". Esta fecha es aceptada de modo unánime por la investigación. Además, en el epitafio del considerado como maestro Pedro de Dios se dice que "superaedificavit ecclesiam hanc". Este pasaje también ha dado lugar a diversas interpretaciones, asociándose a la elevación de la nave mayor para su alumbramiento directo (Díaz-Jiménez 1917: p. 84-85 y 98), a la terminación de las obras (Lampérez 1908-09: p. 461, aula) o a la construcción de las bóvedas (Williams 1993: p. 173 y García Martínez 2005: p. 81).

Dentro de la idea de que la infanta Urraca proyecta una iglesia cubierta en madera, Viñayo (2002: p. 557) propone que la obra de Alfonso VII es un nuevo proyecto que pretende abovedar la nave central con un cañón, lo que obligó a "reforzar el segundo pilar de cada lado, a contar del crucero, muy sencillo, adosando una media columna por la cara de las naves laterales y metiendo la correspondiente del lado opuesto por el centro de una ventana y volteando sobre ellas un arco perpiaño. Todavía fue mayor su audacia al querer rebasar el grosor de los muros altos de la nave mayor sobre los asientos de la arquería y apoyándolos sobre las bóvedas de las naves laterales". Esto supuso que quedaran "mal contrarrestados los empujes de la bóveda central”, deformándose la construcción.

Como epílogo, queda el monarca Fernando II (1157-1188), cuya actividad solo ha sido identificada en el panteón, bien en las bóvedas y pinturas (Gómez Moreno 1925: p. 199), bien solo en las pinturas ${ }^{8}$ (Conant 1959: p. 344, ca. 1175; McCluskey 1994: p. 58, ca. 1160), bien en la reforma de la tribuna (Viñayo 1964: p. 107 y Bango 1992: p. 105, románico en general).

\section{ANÁLISIS DE LA BASÍLICA DE SAN ISIDORO}

La iglesia de San Isidoro posee una planta basilical en cruz latina9. Su aula se divide en tres naves separadas de

\footnotetext{
8 Datadas por otros investigadores a inicios del siglo XII (Williams 1993: p. 173 y Bango 1997: p. 128).

9 Medidas en metros de la basílica actual (según la planimetría fotogramétrica): L total (int) 46,7, (ext) 49,4; L aula 24,65, L crucero 6,70, L ábside central 7,10. A aula (int) 15,5, (ext) 17,7. Nave mayor: A 7,5, H 17. Naves
}

la cabecera triple por un transepto. El ábside principal, con la misma luz que la nave central, fue sustituido en época gótica por otro rectangular mayor cubierto con una bóveda de crucería, restando de la cabecera primitiva únicamente los ábsides laterales menores y los arranques del central. La amplitud total de la cabecera se proyecta un tercio respecto a la línea de los muros longitudinales del aula, siendo por lo tanto más amplia.

Los brazos del transepto se dividen en dos tramos, equivalentes a los ábsides menores, mediante arcos fajones sustentados al interior por columnas semiadosadas y acompañados al exterior por pequeños contrafuertes. El crucero se delimita con dos arcos polilobulados en sus lados norte y sur y uno de medio punto en el oeste. Se debe pensar en la probable existencia de un cuarto arco oriental, desmontado con la introducción mencionada del santuario gótico. Mientras los brazos se abovedan con cañones que discurren en un eje N-S y se refuerzan en sus esquinas con grandes contrafuertes, el crucero se cubre con una bóveda que continúa la dirección E-O y la altura de las correspondientes cubiertas análogas de la nave central.

El aula se articula en tres naves, mayor la central, de seis tramos originados por dos arquerías de arcos peraltados doblados que descansan sobre pilares cruciformes compuestos con columnas entregas por cada frente. Las arquerías sostienen los muros de la nave central, iluminada con sendos ventanales arcuados y cubierta con una bóveda de cañón reforzada por arcos fajones. Estos se refuerzan con robustos contrafuertes al exterior. Los seis tramos de las naves laterales se cubren con bóvedas de aristas, separadas de nuevo por arcos transversales que arrancan respectivamente de las semicolumnas en los muros longitudinales y de los pilares cruciformes de las arquerías. Mientras que los cuatro tramos occidentales del aula se cubren con bóvedas de ladrillo, los restantes lo hacen en piedra.

El análisis realizado en su fábrica obtuvo una prolongada secuencia formada por seis periodos que discurren desde mediados del siglo XI hasta inicios del XXI (Fig. 2). De esta dilatada historia, solo exponemos a continuación los dos primeros periodos, aquellos que comprenden desde mediados del siglo XI a mediados del XII, los cuales han situado a San Isidoro en todos los catálogos artísticos del Románico. Las referencias a los periodos posteriores se reducen a las necesarias para la comprensión de la evolución aquí expuesta (Fig. 3).

laterales: A 3,20 (S), A 2,70 (N), H 8,50. Transepto L (int) 27,5, (ext) 29,6, A 6,7 . 


\begin{tabular}{|c|c|c|c|}
\hline Periodo I & & ca. 1063 & Obra en el ángulo noroccidental del aula de la actual basílica \\
\hline \multirow{3}{*}{ Periodo II } & IIa & Inicios s. XII & Construcción de una basílica de tres naves, tres ábsides y transepto \\
\hline & $\mathrm{IIb}$ & & Ruina de los cuatros tramos occidentales (muros y bóvedas) del aula \\
\hline & IIc & Mediados s. XII & $\begin{array}{l}\text { Restauración de los cuatro tramos occidentales del aula, introduciendo } \\
\text { contrafuertes meridionales, bóvedas de ladrillo y reconstruyendo su } \\
\text { puerta meridional (Puerta del Cordero) }\end{array}$ \\
\hline \multirow[t]{4}{*}{ Periodo III } & IIIa & $1 / 2$ s. XIV & Capilla funeraria meridional, en el ángulo entre el transepto y el aula \\
\hline & & $\begin{array}{l}\text { Pre-mediados } \\
\text { del s. XVI }\end{array}$ & Puerta en el testero occidental y piso alto a los pies del aula \\
\hline & $\mathrm{IIIb}$ & $2 / 4$ s. XVI & Coro alto a los pies del aula \\
\hline & IIIc & Inicios s. XVI & $\begin{array}{l}\text { Ábside mayor de la basílica. Capilla de los Quiñones (norte). Claustro } \\
\text { en lado norte (conocido como del abad Fonseca). Arcosolios en lados } \\
\text { sur y este del claustro y en el ángulo de la fachada y el brazo norte del } \\
\text { transepto. Biblioteca a los pies del aula. Puerta y pinturas de la Cámara } \\
\text { de Doña Sancha }\end{array}$ \\
\hline Periodo IV & & Ss. XVII-XVIII & $\begin{array}{l}\text { Transformaciones menores en la puerta oeste y en los arcosolios. } \\
\text { Inserción mobiliario litúrgico. Segundo piso del claustro norte. Crestería } \\
\text { de la fachada sur. Trasaltar. Habitación sobre la Cámara de Doña Sancha }\end{array}$ \\
\hline \multirow[t]{2}{*}{ Periodo V } & $\mathrm{Va}$ & Inicios s. XIX & Incendio del interior \\
\hline & $\mathrm{Vb}$ & Finales s. XIX & Reparaciones empleando yesos (principalmente elementos decorativos) \\
\hline \multirow[t]{3}{*}{ Periodo VI } & VIa & Inicios s. XX & Restauraciones de J. C. Torbado: reposición de piedra en el interior \\
\hline & $\mathrm{VIb}$ & $\begin{array}{l}\text { Mediados s. XX } \\
(1958-74)\end{array}$ & $\begin{array}{l}\text { Restauraciones de L. Menéndez Pidal: excavaciones y pavimentación, } \\
\text { atirantado de la nave mayor y reconstrucción del claustro, entre otros }\end{array}$ \\
\hline & VIc & Finales s. XX & Restauraciones actuales: limpieza de superficies \\
\hline
\end{tabular}

Fig. 2. Síntesis de los Periodos posteriores de San Isidoro

\section{Periodo I. Edificio Primitivo}

[A 100. UE 1072; A 101. UE 1071, 1108,

$1215,1217,1290,1324]$

\section{Análisis arqueológico}

El análisis identifica una primera obra [A 100 y 101] en el ángulo noroeste del actual aula (Fig. 1), de la cual únicamente conservamos parte del muro norte con un acceso de arco de medio punto flanqueado por contrafuertes [UE 1071, 1108 y 1290] y parte del muro oeste con un vano bajo y otro alto acompañado de una pareja de óculos [UE 1215, 1217 y 1290].

Una primera hilada [UE 1072] en el muro norte, a modo de zócalo (saliente $0,3 \mathrm{~m}$ ), discurre hasta la jamba occidental de la puerta (Fig. 4). En el oeste, lo hace hasta la jamba norte de la puerta meridional con el tímpano de crismón (Fig. 5). En el resto de este frente, la hilada ha sido picada y eliminada. El muro norte [UE 1071] tiene una longitud de 12,00 $\mathrm{m}$ hacia el este y una altura de 5,75 m (Fig. 4). Hacia su mitad, se abre una puerta ( $\mathrm{H} 4,50 \mathrm{~m}, \mathrm{~A} 2,00$ $\mathrm{m})$ con un arco de medio punto dovelado y con tímpano de ladrillo [UE 1108, A 101]. Este muro se reforzó al exterior (Fig. 6) con unos contrafuertes (A 0,66 m), convertidos en arcos en el Periodo II y ampliados en las restauraciones del
Periodo VI, por lo que ignoramos cómo eran en origen. Solo conocemos algunos de sus arranques trabados con el muro. Dos parejas flanquean el vano norte. Otros dos se localizan en los extremos oeste y este del muro.

Las indagaciones de Williams (1973: p. 176), a raíz de las restauraciones de Menéndez Pidal (1964), constataron un sistema de escalonado de tres saltos en este muro norte y de dos de los respectivos contrafuertes a una altura de 4,40 $\mathrm{m}$ respecto al nivel del suelo actual (Fig. 7) ${ }^{10}$. Los arcos del Periodo II rompen los contrafuertes en la parte alta y los transforman en arcos en la parte baja. De ahí la irregularidad de este sistema arcuado posterior, el cual debe adaptarse a unos contrafuertes preexistentes no equidistantes.

La cara oeste (Fig. 8) del muro occidental [UE 1215 y 1217] está protegida por el panteón ${ }^{11}$. Entre pilares

\footnotetext{
10 La proyección más allá de la línea del muro de este elemento confirma que son contrafuertes, no jambas de ventanas, como propone Fernández González (2009: p. 50).

11 Este espacio se designa como panteón desde 1693, cuando se realizó una lista de sus tumbas. Por carácter práctico, empleamos este término, sin con ello pretender reflejar su uso real. Por el mismo motivo, usamos el de "Cámara de Doña Sancha" para referirnos al piso alto del mismo. Ni cámara ni panteón han sido analizados, por lo que solo nos referimos a ellos cuando es estrictamente necesario para exponer la secuencia de la basílica. Por ello, tampoco podemos analizar la relación constructiva y temporal de estos espacios con la basílica.
} 

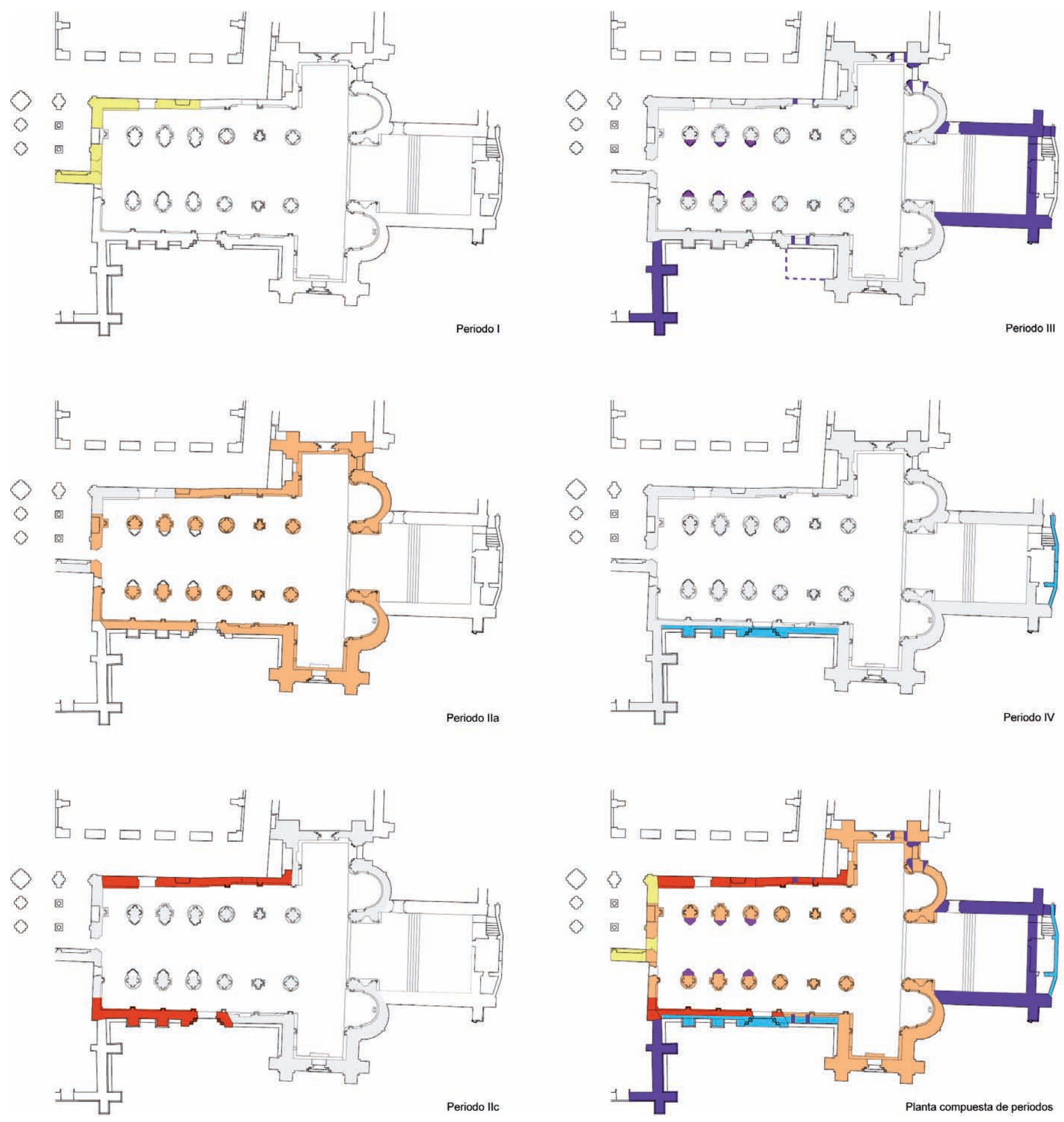

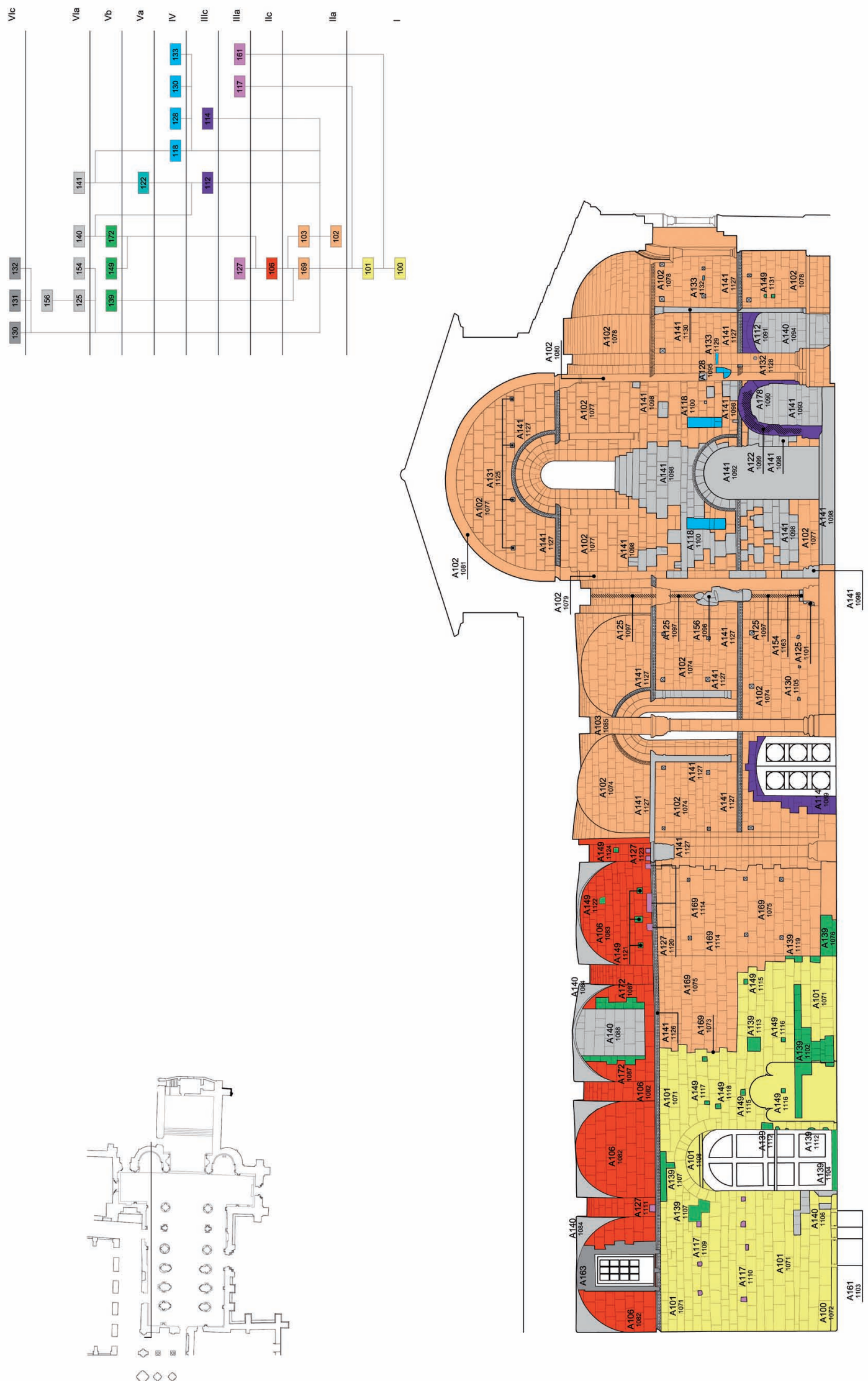


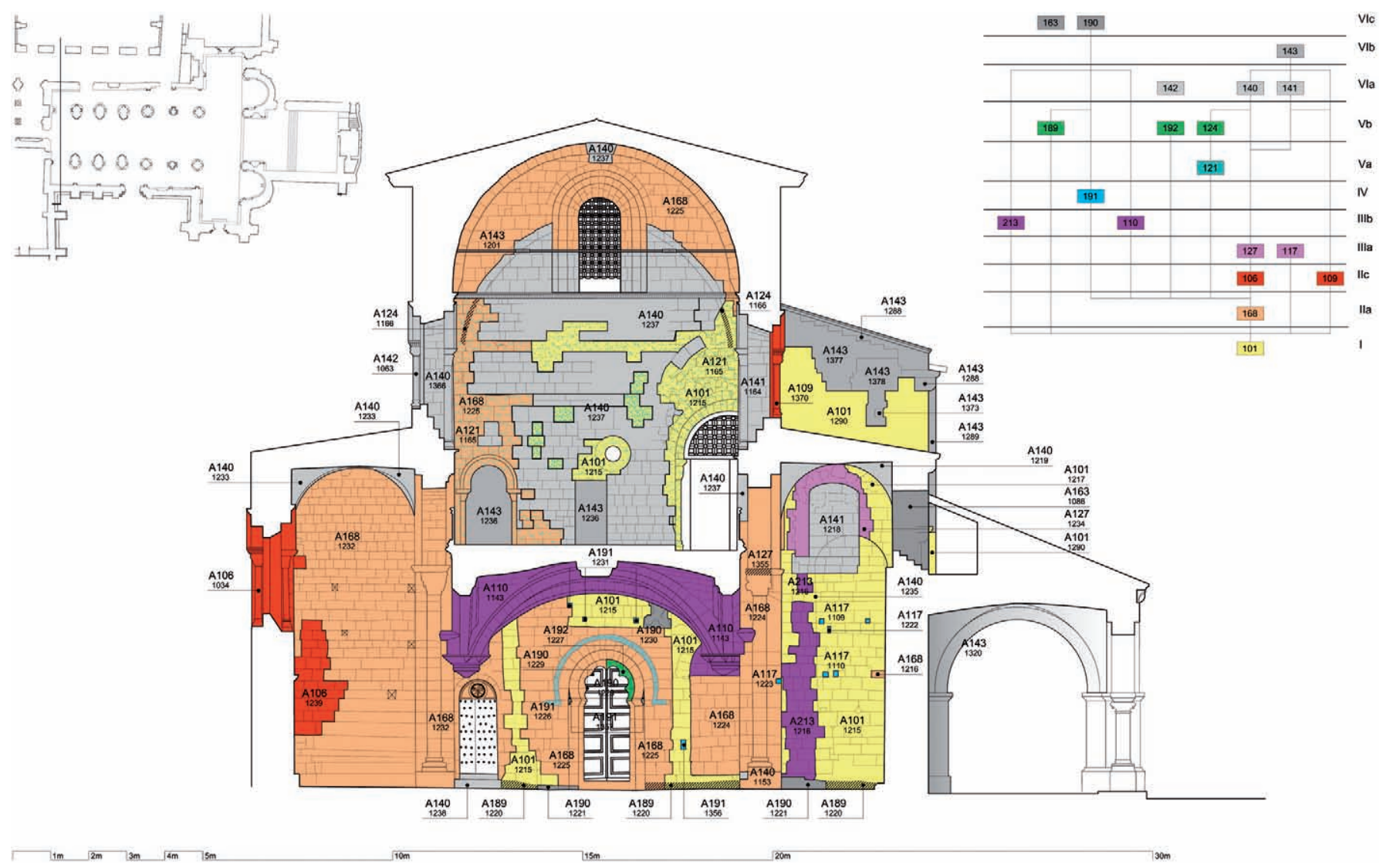

Fig. 5. Alzado interior del testero occidental de San Isidoro

con zócalos ataludados, se abre un vano central, de medio punto dovelado en el lado este y con dintel de tres piezas y tímpano macizo en el oeste, evidenciando que al oeste/ exterior debió existir una estructura desde la que se ingresaba, de acuerdo a la disposición arco este - tímpano oeste (Fig. 9). Sobre esta puerta hay otra alta de doble arco. Su arco exterior descansa sobre jambas rectas, mientras que el interior lo hace sobre un orden de cimacios, capiteles con motivos figurados, fustes cilíndricos y basas clásicas ${ }^{12}$. A la altura de sus impostas, el arco estaba flanqueado por dos óculos circulares simétricos ${ }^{13}$. La parte alta del muro se completa con un arco, del cual se conservan únicamente dos dovelas de su arranque sur (Figs. 5 y 10). Prolongado con otras dos dovelas por las restauraciones de Torbado (Periodo VI), pudo funcionar como arco de descarga del vano alto o formar parte de una eventual bóveda, tema sobre el que volveremos más adelante.

\footnotetext{
12 Según Pérez Llamazares (1927: p. 338), la denominada tribuna "parece tenía antepecho que caía al interior de la iglesia, pues aparecieron restos de las ménsulas".

13 El óculo norte está oculto por las actuales bóvedas y cubiertas de la nave norte. Solamente es reconocible en la cara oeste del muro, ya dentro de la Cámara de Doña Sancha (Fig. 8).
}

Ambos muros norte y oeste se alzan en sillería caliza dispuesta en hiladas horizontales, con filas altas $(0,40$ $\mathrm{m})$ alternadas con otras más bajas $(0,15-0,20 \mathrm{~m})$, cuya unión se ayuda a veces de engatillados y saltos (Fig. 11). Los sillares fueron tallados a pie de obra con un cincel o pico pequeño, dejando huellas longitudinales con una inclinación de $45^{\circ}$ (Fig. 12) $)^{14}$, y alzados con los andamios sin agujas pasantes, como evidencia la ausencia de mechinales. No tienen marcas de cantero. Se emplean de manera indistinta sogas y tizones y muy esporádicamente el ladrillo (L 255, A 135, H $60 \mathrm{~mm}$ ) en vertical $\mathrm{y}$ en horizontal, en zonas de ajuste como las esquinas o los ángulos entre pilares y muros. Las juntas estaban además selladas con un estrecho encintado en relieve terminado con la punta de una herramienta.

Los muros altos norte (Fig. 6) y este (Fig. 5) del panteón [UE 1290], aunque fuera de los límites del estudio,

\footnotetext{
14 Gómez Moreno (1934: p. 59) cree que es un pico y Menéndez Pidal (1964: p. 73 , n. 20) que es una escoda. El primero añade que el núcleo del muro es de cantos fraguados con un mortero de cal muy duro. Este tipo de obra se ve en el alzado oeste, bajo el coro alto, en una zona donde se han perdido los soportes de este primer edificio.
} 

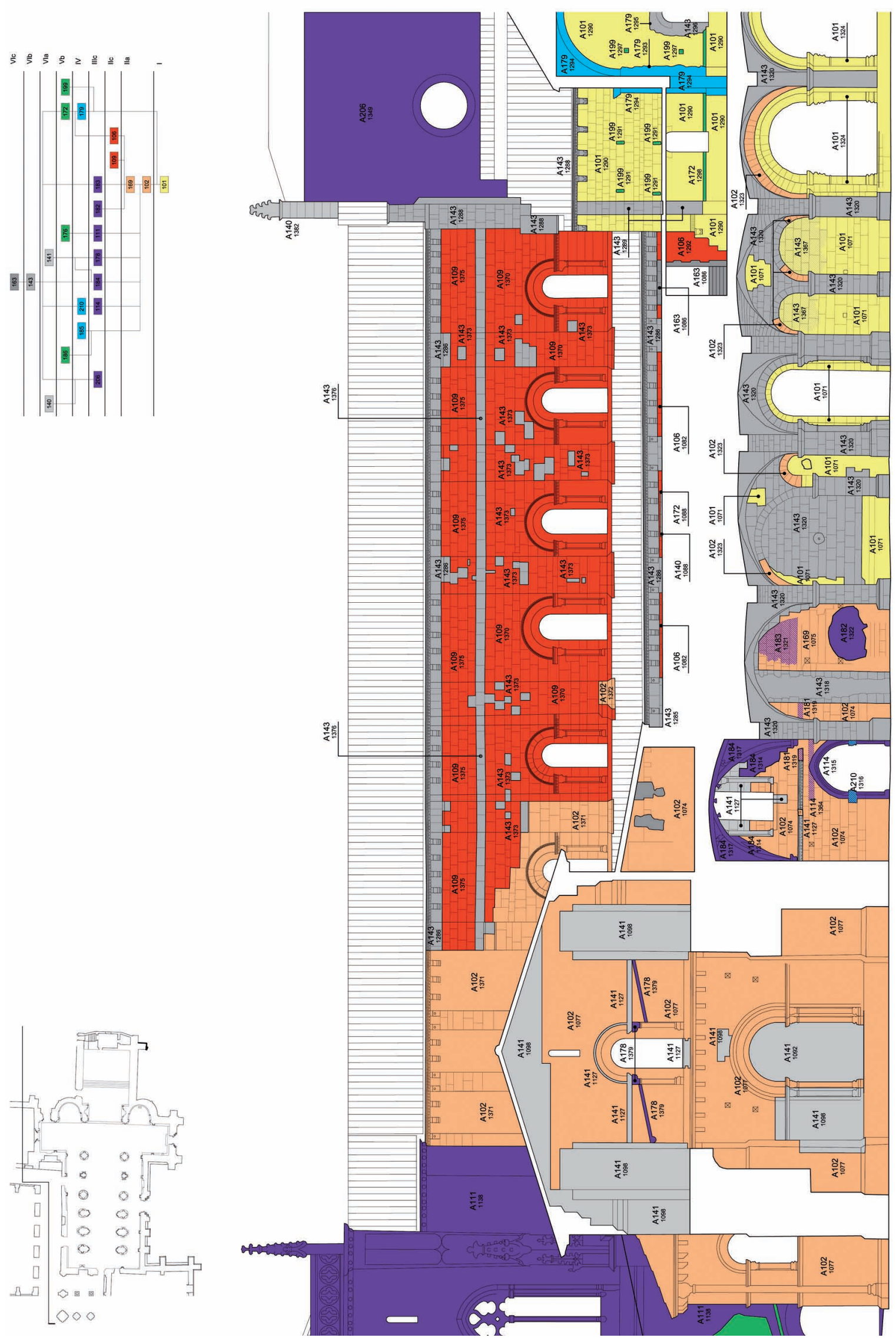


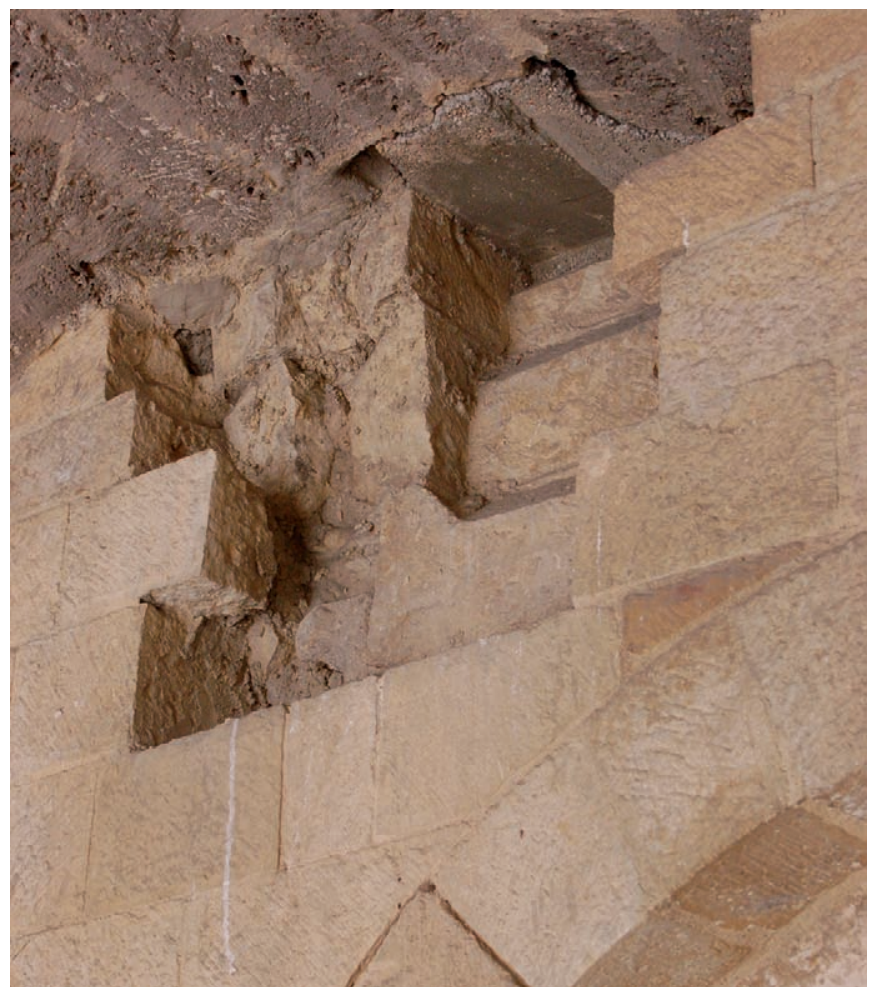

Fig. 7. Restos del escalonamiento del muro norte [UE 1071, A 101] visibles en el exterior del primer tramo occidental detrás de los arcos restaurados por L. Menéndez Pidal
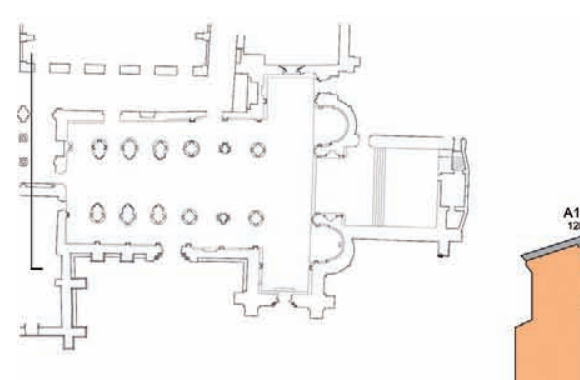


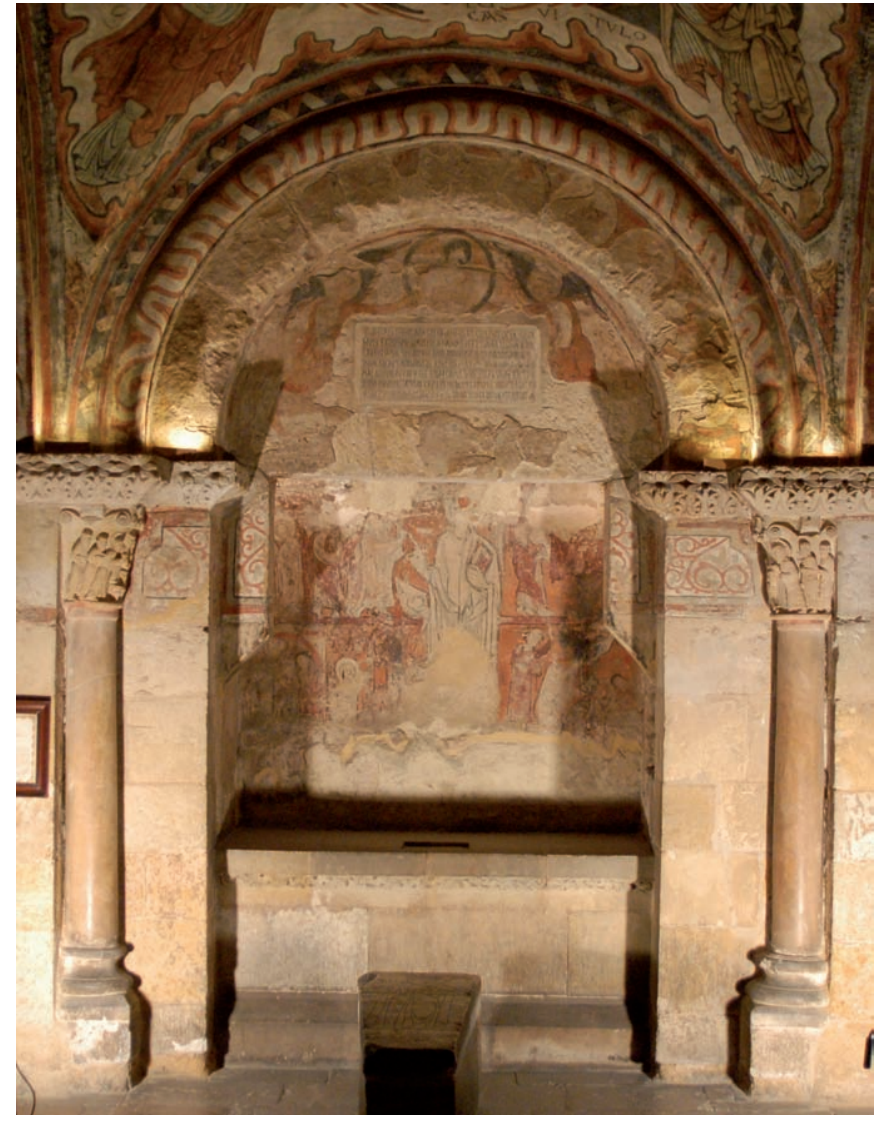

Fig. 9. Vano central del muro oeste [UE 1215, A 101], inscripción de Fernando I y Sancha (trasladada aquí, [UE 1331, A 202]) y posterior conversión en nicho [UE 1326, A 174]

fueron analizados para poder secuenciar los paramentos septentrionales descritos. Estos muros muestran las mismas características: sillería caliza en hiladas horizontales, tallada a cincel, sin marcas de cantero, con juntas en relieve y escasa presencia de ladrillo. El muro norte del panteón dobla en su extremo oriental hacia el sur, unificándose así con el muro oeste del aula. Sobre el tejado del claustro bajo, se observa ${ }^{15}$ cómo el tramo visible del muro este [UE 1290, Fig. 5] recibe el muro norte de la nave central [UE 1370], confirmando su anterioridad. El adosamiento de la UE 1292 (Fig. 6) de la etapa románica, tampoco deja lugar a duda de la anterioridad del muro norte y, por ello posiblemente, del panteón y de la cámara. El muro norte [UE 1290] tiene una ventana de medio punto y jambas abocinadas. Junto a ella y a $0,55 \mathrm{~m}$ de la esquina oeste, un contrafuerte de $0,45 \mathrm{~m}$ de ancho y 0,22 $\mathrm{m}$ de proyección se alza a lo largo del muro. Este refuerzo continúa el del piso inferior. El hecho de que el muro

\footnotetext{
15 Observación realizada desde el ala oriental del claustro, a una distancia aproximada de $35 \mathrm{~m}$ y sobre una fotografía como único soporte gráfico, por lo que no podemos añadir datos descriptivos de detalle.
}

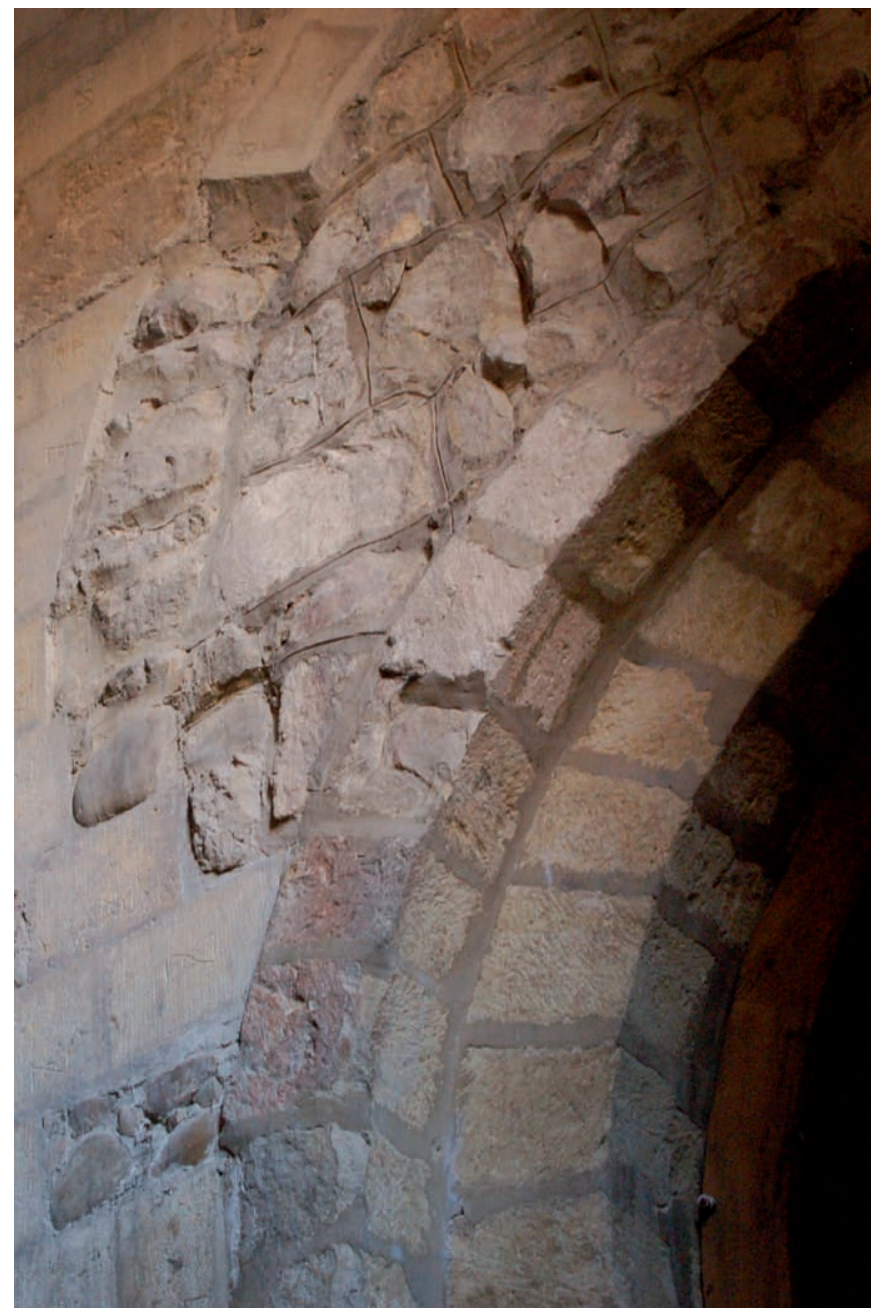

Fig. 10. Arranque meridional del arco superior [UE 1215, A 101] restaurado por ]. C. Torbado [UE 1237, A 140]

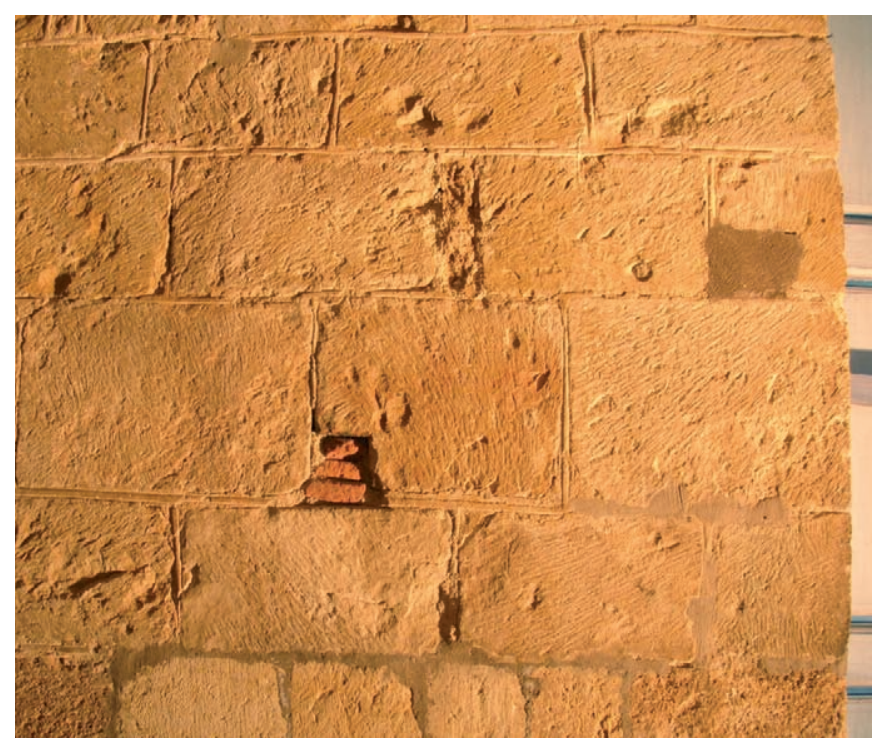

Fig. 11. Detalle de la fábrica del Periodo I, jamba occidental del vano norte [UE 1071, A 101] 


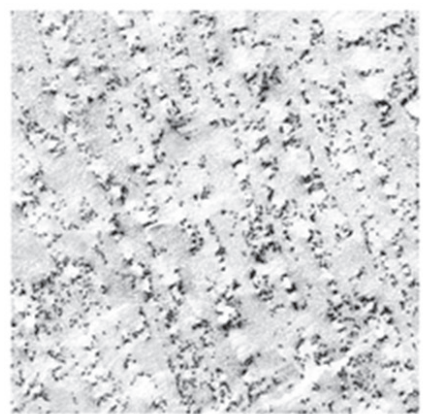

Periodo I. A101. UE1071

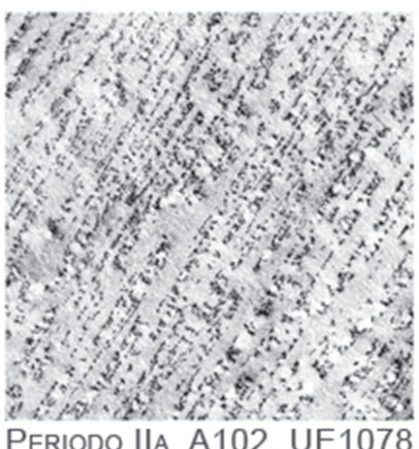

Periodo IIa. A102 UE1078

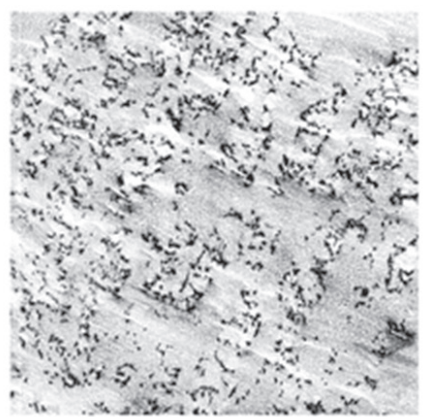

Periodo I. A101. UE1071

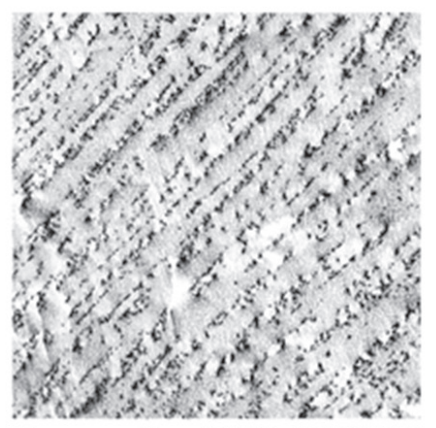

Periodo Ila. A102. UE1075

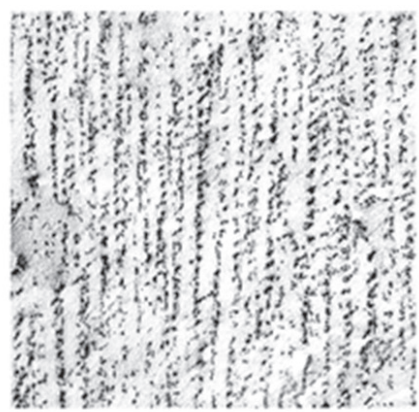

PERIOdo IIC. A107. UE1038

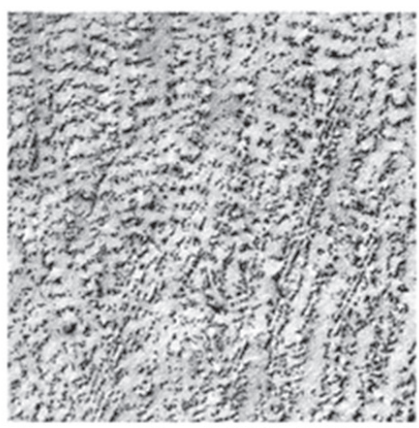

PERIOdo IIIC. A111. UE118

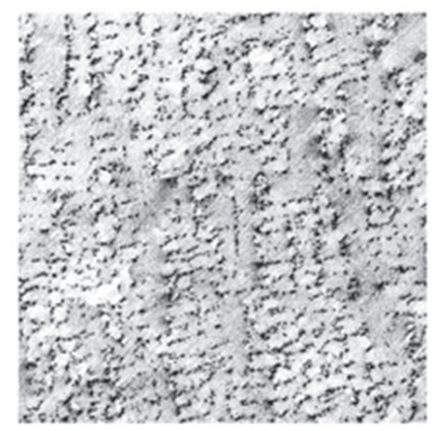

Periodo IIIb. A110. UE1143

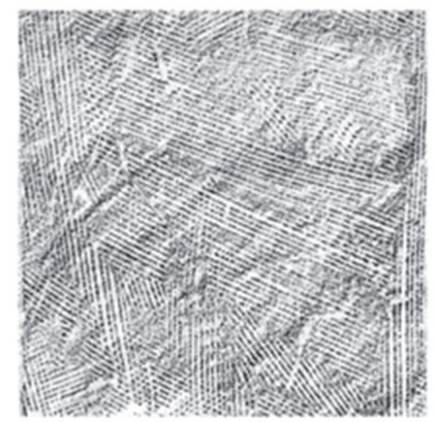

PERIOdo IIIC. A111. UE1182

Fig. 12. Calcos de las tallas de la sillería ordenados por periodos

norte de la cámara alta del panteón [UE 1290] sea de este Periodo I fuerza a que los arcos [UE 1324] situados bajo él y que abren el panteón al claustro también lo sean (Fig. 6). Estos arcos dobles descansan sobre pilares cruciformes asentados sobre un zócalo solidario con el muro sur y sobre una semicolumna oriental que une con los muros de la basílica [UE 1071 y 1215]. Estos elementos carecen de marcas de cantero y se tallan de la misma forma.

Desde el lado este del contrafuerte y hasta la esquina del panteón (Fig. 6), una imposta de talla ajedrezada recorre la parte alta del muro de la nave, sustentada por un modillón figurado de cabeza antropomorfa (Fig. 13). Esta imposta debe tomarse como referencia a la hora de calcular las alturas de las cubiertas exteriores, las cuales quedarían por encima de las bóvedas laterales tradicionalmente propuestas al interior (Fig. 14), como veremos.

\section{Consideraciones generales sobre el Periodo I}

Contamos con una primera obra (Fig. 3) de la cual únicamente conservamos parte del muro norte con un acceso de arco de medio punto flanqueado por contrafuertes y parte del muro oeste con un vano bajo y otro alto flanqueado por una pareja de óculos. Estos restos han sido interpretados como parte de una basílica de tres naves con cabecera tripartita recta, con el ábside central ligeramente adelantado, y adscrita al reinado de Fernando I

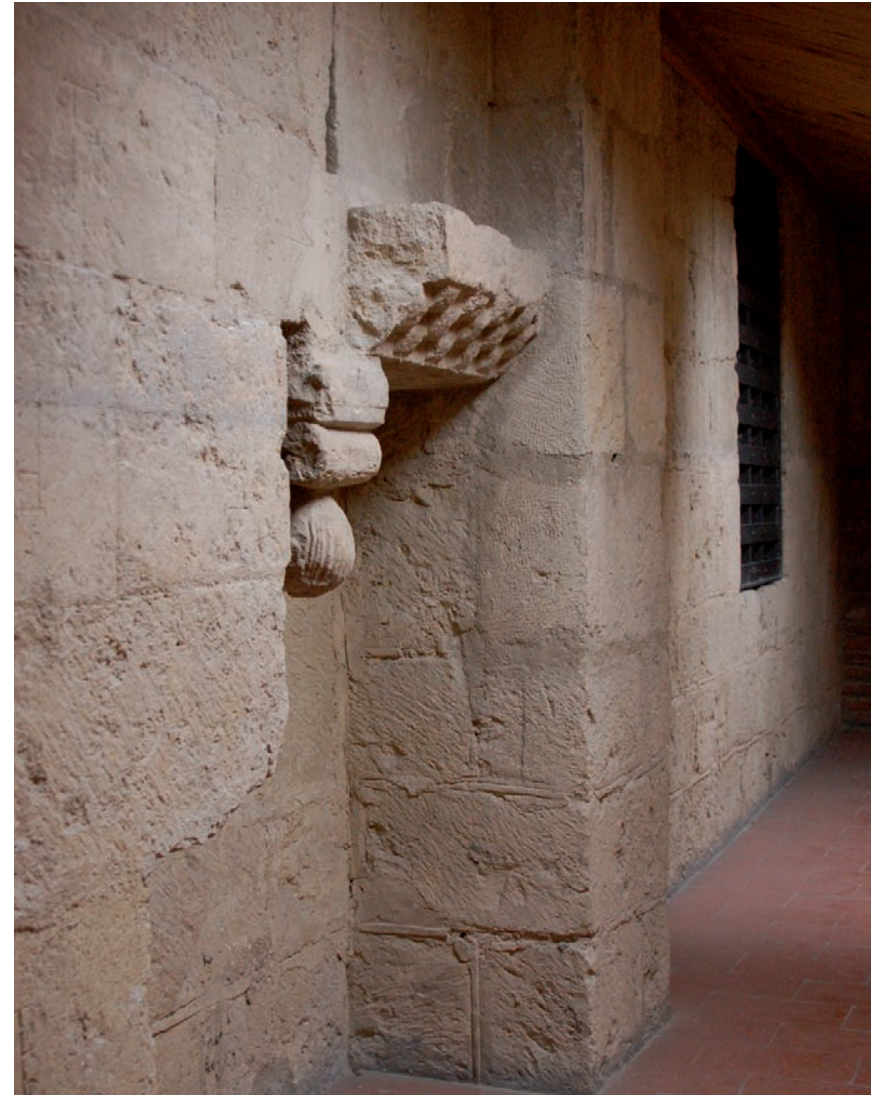

Fig. 13. Modillón e imposta de la nave norte [UE 1290, A 101] y superposición del muro románico (Periodo II: UE 1292, A 106) sobre él 


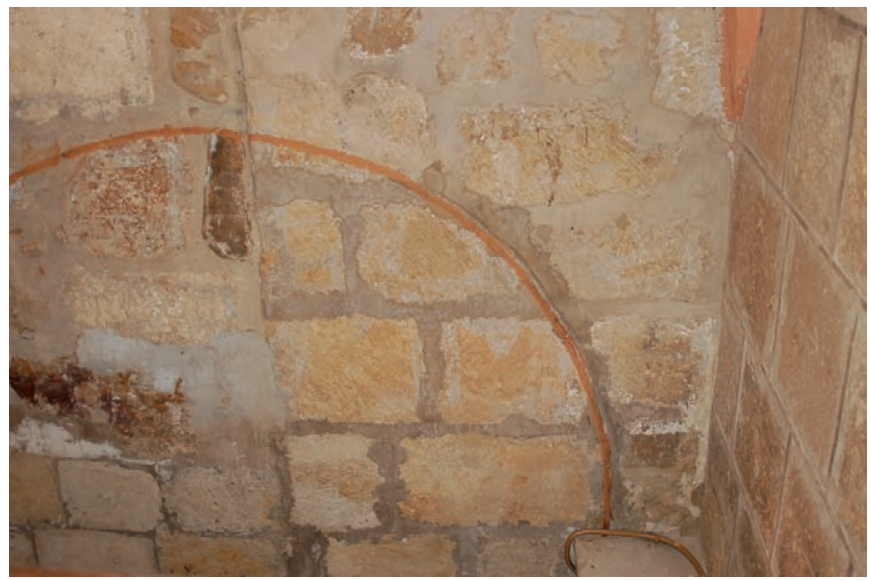

Fig. 14. Ángulo noroeste del interior del aula [UE 1215, A 101], donde se observa la línea dibujada por J. C. Torbado [UE 1235, A 140] marcando el supuesto perfil de la bóveda norte

y Sancha (1063), según la inscripción correspondiente, junto al panteón y a un probable claustro norte. Esta propuesta se reforzó con las inspecciones del subsuelo realizadas a principios del siglo XX a los pies de la iglesia, las cuales sacaron a la luz una serie de estructuras que parecían definir un edificio de tres naves, cuyos únicos muros conservados en alzados serían los tramos norte y oeste descritos (Fig. 15). Los datos obtenidos en el análisis invitan a revisar esta propuesta.

- Los muros hallados en excavación. Los trabajos en el subsuelo del edificio realizados por el arquitecto J. Crisóstomo Torbado a inicios del siglo XX quedaron inéditos. La primera mención se debe a Mélida (1910: p. 151), quien habla del hallazgo de los "cimientos y muros de fachada y lado del Evangelio de una basílica pequeña de tres naves y tres ábsides". Díaz-Jiménez (1917: pp. 92-94) aporta más detalles y dice que salieron a la luz "cuatro líneas de cimentación, que arrancando del muro divisorio de la iglesia y el panteón, se extendían hasta rebasar las terceras pilas". A pesar de que solo menciona los muros longitudinales, no duda en reconstruir una basílica de cabecera triple, con la capilla central ligeramente adelantada, y totalmente abovedada, de acuerdo a los vestigios de las bóvedas norte y central visibles en el paramento interior de la fachada oeste, rematada en su lado meridional con un pórtico, cuyos cimientos coincidirían con la arquería sur actual. Ni Mélida ni Díaz-Jiménez hacen mención a un muro de dirección norte-sur atribuible a la cabecera, pero el segundo (1917: p. 151) lo incorpora en su plano (Fig. 16). Este muro oriental tiene sus caras rectas en la nave norte, pero su perfil exterior es sinuoso en las naves central y sur, reduciéndose a una estrecha faja en el espacio considerado como pórtico. Los cimientos tienen grosores desiguales. Si en la nave norte,

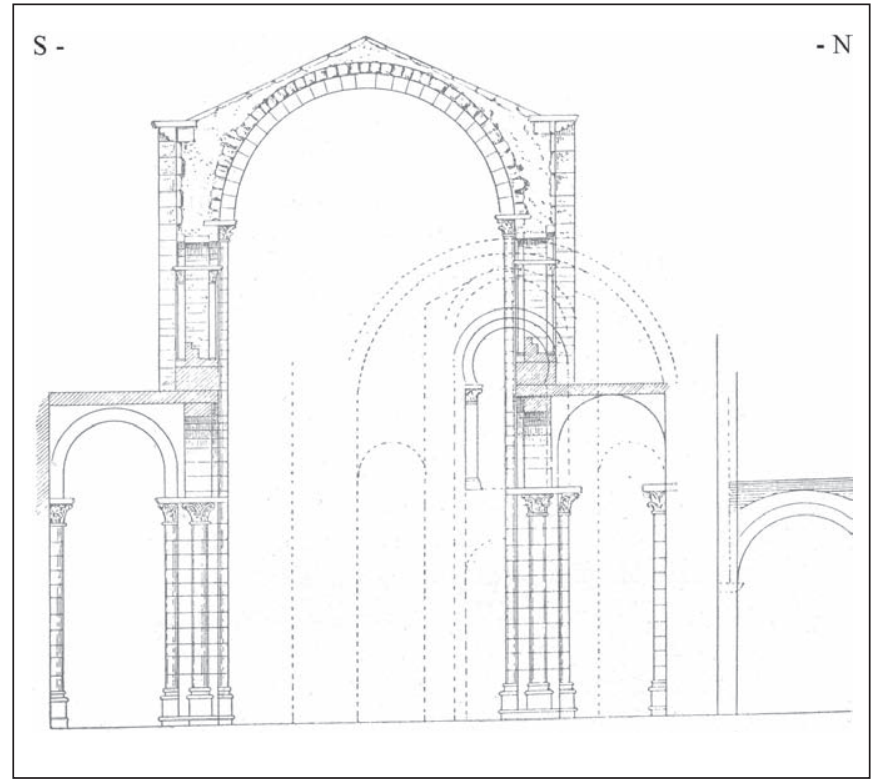

Fig. 15. Sección transversal de la basílica actual con la recreación (en discontinuo) de la altura de las naves localizadas bajo el solado (DíazJiménez 1917: p. 90)

el vacío de la trama del cimiento corresponde a la puerta original, en el muro oeste lo hace con los vanos románicos, no así con el original. Es decir, la ausencia y presencia de los cimientos no corresponde con la secuencia de los vanos originales y posteriores. Por último, remarca un pequeño saliente en el ángulo noroeste de la nave central.

Gómez Moreno (1934: p. 61) uniformiza el plano de Díaz-Jiménez (1917). Iguala la luz de las naves laterales y recrea una cabecera tripartita con capilla central saliente y muros regulares (Fig. 16). Insinúa con una trama de puntos los grosores de los muros sobre los cimientos, cierra el cimiento del vano de la nave meridional y abre el de la central. En la mitad oriental del cimiento norte de la nave central añade un saliente rectangular, sin parejo en el muro contrario y sin explicación aparente. Del pórtico sur, dibuja el arranque oriental, pero no se compromete con los restantes muros.

Como ya señaló Muir Whitehill (1939: p. 146), llama la atención la diferencia entre las medidas de las plantas de Díaz-Jiménez (1917) y Gómez Moreno (1925), quien las modifica posteriormente (Gómez Moreno 1934). Entre ambas reconstrucciones hay casi dos metros $(1,82 \mathrm{~m})$ de diferencia en la amplitud total del templo propuesto (Fig. 17) ${ }^{16}$.

El plano de Gómez Moreno (1934) es reproducido sin modificaciones por Camps (1935: p. 40), Muir Whitehill

\footnotetext{
16 Otras medidas en Pérez Llamazares (1927: p. 335): nave central L 13,05, A 3,30 m; laterales L 11,80, A 1,50 m.
} 


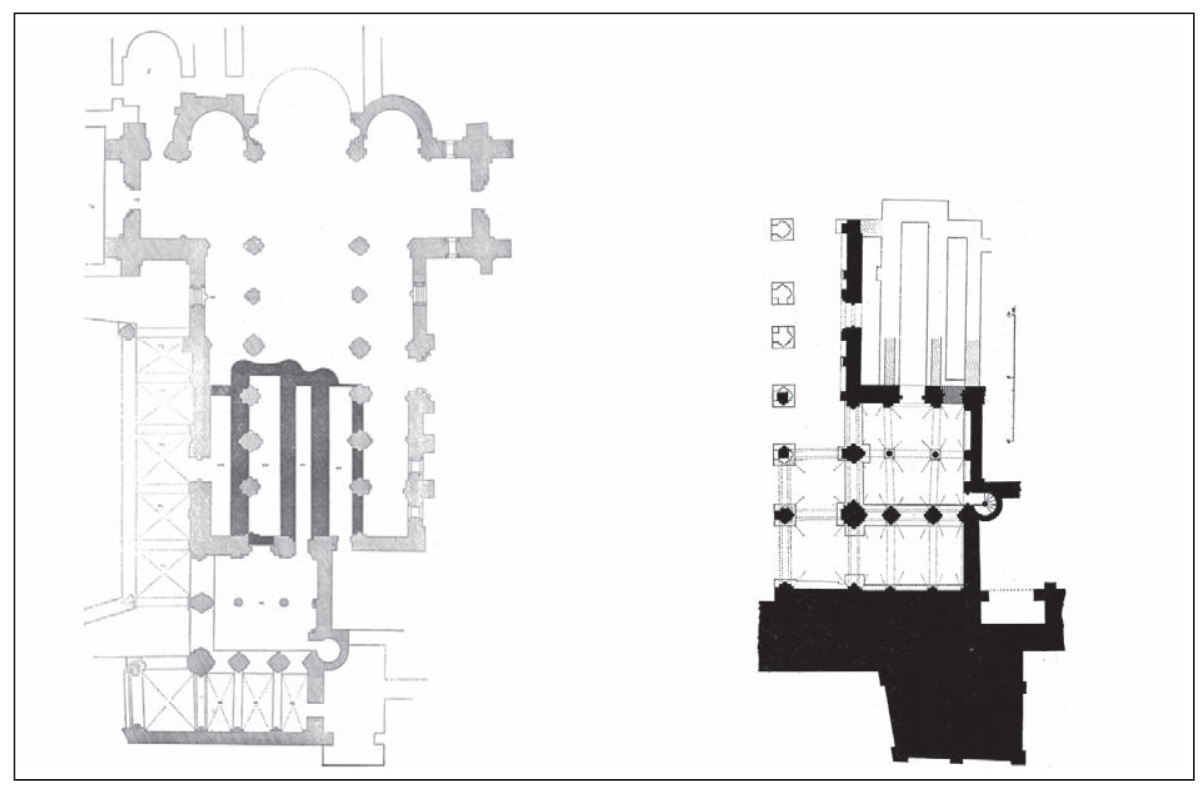

Fig. 16. Planta de la basílica con los restos documentados en los trabajos de J. C. Torbado, destacados en negro según Díaz-Jiménez (1917: p. 93) y en trama punteada según Gómez Moreno (1934: p. 61)

\begin{tabular}{|c|c|c|c|}
\hline & Díaz-Jiménez 1917 & Gómez Moreno 1925 & Gómez Moreno 1934 \\
\hline Nave central & L 13,05 A 2,30 H 12 m & A 3,30 H 12,15 m & A 3,10 H 11,60 m \\
\hline Nave norte & L 11,80 A 1,50 H 6,80 m & A 1,65 m & A 1,83 H 6,80 m \\
\hline Nave sur & L 11,80 A 1,15 H 6,80m & A 1,65 m & A 1,83 H 6,80 m \\
& & $\begin{array}{c}\text { Muros interiores A 0,75 m interiores A 0,74 m } \\
\text { Muro N A 1,40 m }\end{array}$ \\
\hline
\end{tabular}

Fig. 17. Medidas comparadas de los planos de Díaz-Jiménez y Gómez Moreno [A anchura, L longitud, H altura]

(1939: p. 144), Menéndez Pidal (1964: p. 75) y Viñayo (1964: fig. 1), entre otros. Los trabajos de Williams, realizados a finales de los años 70, permanecieron también inéditos. Solo en un breve artículo, Williams (1973: p. 171, n. 5) menciona que J. C. Torbado "discovered the foundations of a three-aisled church with squared apses and a southern porch", descripción que se basa sin embargo en los artículos de Mélida (1910) y Díaz-Jiménez (1917), cuyo plano ilustra su trabajo. Debemos entonces suponer que Williams tampoco vio la documentación original de Torbado, si es que esta existió. En un breve epílogo al final de su texto, Williams (1973: p. 184) adelanta que en los trabajos dirigidos por él no se hallaron trazas del porche meridional.

El plano anunciado por Williams en 1973 fue finalmente publicado en el periódico Diario de León, con fecha de 12 de Abril de $2008^{17}$. De mayor detalle que los conocidos hasta ahora, este plano permite realizar algunas puntualizaciones (Fig. 18). Mientras los cimientos de la nave norte se alinean con el muro actual, los correspondientes occidentales siguen una ligera (des)orientación noroeste-sureste, provocando el estrechamiento del extremo

\footnotetext{
17 Agradecemos al arquitecto R. Cañas la copia de este artículo. Reproducido también en Williams (2011: fig. 7).
}

oeste del muro sur de la nave central. Precisamente este muro, de perfil irregular, es recorrido por canalizaciones, las cuales se pierden bajo el muro común con el panteón y se repiten en el mismo extremo oeste del muro sur. Estos canales ya fueron advertidos por Viñayo (1978: p. 228), quien debió ser testigo de su hallazgo durante los trabajos de Williams: "¿Por qué no se hace constar que en los muros de cimientos apareció a todo lo largo de los mismos un canalillo cuya finalidad no se ha podido determinar, que recorre los muros de la iglesia y, sin solución de continuidad, se introduce en los actuales del panteón?". La mitad sur de esta estructura está parcialmente perdida, por lo que no se puede reconocer la línea exterior de lo que se ha supuesto como ábside sur ni tampoco del muro sur, ambos representados por líneas irregulares, tal vez reflejando su ruina. Una tumba antropomorfa, seguramente infantil (L máx $1,10 \mathrm{~m})^{18}$, corta el cimiento del muro oriental. El saliente de tres sillares del muro norte de la nave central corresponde al dibujado por Gómez Moreno (1934), así como la

\footnotetext{
18 El plano de Williams (2008) solo representa una tumba, pero él mismo (1971: p. 14) afirma que halló dos sepulturas infantiles dentro del recinto de la iglesia de Fernando I. Según una reciente nota (Williams 2011: p. 116), la segunda estaría dentro del espacio interpretado como nave norte (¿Trama punteada en su extremo oeste?).
} 


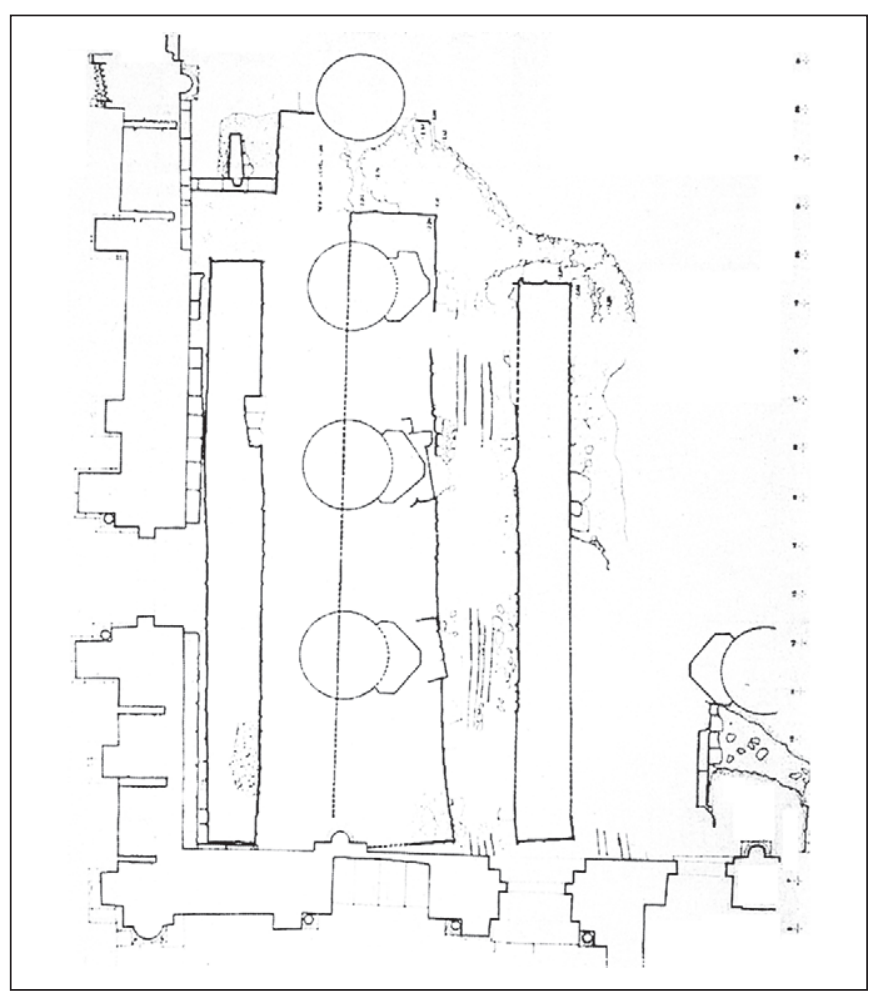

Fig. 18. Plano de las excavaciones en el ángulo noroeste del aula publicado por Williams (2008)

"desaparición" del denominado pórtico. Se observa así la irregularidad de una planta que puede reflejar en realidad elementos de distintos momentos, tal como insinuó Viñayo (1964: p. 106 y 2007: p. 93) al referirse al hallazgo de muros romanos y de los cimientos de la iglesia.

Boto (2007: p. 57) introduce un nuevo argumento. En su opinión, el muro oriental no sería el testero de la cabecera, sino el cimiento continuo de la embocadura de una cabecera triple de ábsides semicirculares. La ausencia de articulaciones entre los espacios que corresponderían al aula y a la cabecera le hace retrasar unos metros esta última, la cual debió diferenciarse de alguna manera. Crea así una basílica de mayor longitud y de formato plenamente románico.

- Los muros hallados en excavación y las UE murarias. La lectura de paramentos considera el tramo oeste del muro norte hasta el tercer pilar y sus correspondientes cimientos (Fig. 4), así como la fachada oeste con el vano hoy sellado (Fig. 5) como originarios de esta primera fase. Los cimientos del muro oeste continuaban hacia el sur, aunque fueron picados posteriormente (Periodo $\mathrm{Vb}$ ). Sin embargo, a partir del punto que marca el pilar norte de la arquería actual en su encuentro con el muro oeste, los cimientos dibujados por Williams (2008) giran hacia el sureste (Fig. 18). Al mismo tiempo, el cimiento del muro norte montaría sobre el muro corrido documentado en las excavaciones.
En ambos muros se daría por tanto lugar a un anómalo sistema de dos cimientos: el zócalo hoy visible en el muro norte montaría sobre las cimentaciones exhumadas en las excavaciones, lo que indicaría en realidad la existencia de dos estructuras distintas. Lo mismo parece indicar el extremo oriental de las excavaciones, cuyo cimiento dobla hacia el sur. Su pérdida debería haber dejado huella en el alzado norte, sobre el cual se monta de modo escalonado el muro de la ampliación románica. Es decir, no hay una esquina que corresponda a la de la excavación y que evidencie que el edificio terminaba allí. Por último, los contrafuertes conservados parcialmente en el alzado norte no tendrían sus correspondientes en el muro sur excavado.

A esto hay que sumar las huellas en el muro occidental, asociadas al abovedamiento de las naves (Fig. 5). Las roturas y reparaciones del muro (Periodo IIIb) indican la presencia de unas cabezas de muros o pilares terminales de arquerías, cuya pérdida dejó en el muro unas rozas verticales. Siguiendo la línea de la reparación en la nave norte, Torbado marcó en negro una línea recta que correspondería al soporte norte y que continúa en una curva que sería el perfil de la bóveda norte (Fig. 14). Esta línea pasa sin embargo por encima del tapiado de la puerta abierta posteriormente (Periodo IIIa), por lo que Torbado no pudo ver aquí traza alguna de la bóveda. Únicamente pudo apreciarla en el ángulo noroeste. En este punto, maltratado por varias superficies de cemento, las hiladas sobre la imposta, de factura algo más irregular y juntas gruesas, se adosan al muro norte del aula, lo que confirmaría su pertenencia a un periodo posterior (Periodo IIc). Solamente los dos sillares inmediatos a la jamba norte de la puerta, situados a la izquierda de la línea curva dibujada por Torbado, pudieron pertenecer al tímpano de la bóveda, si se da por buena la línea citada.

Un segundo dato a considerar en esta reconstrucción tradicional es la carencia de indicios seguros sobre la situación de la bóveda central, a la cual únicamente se la podría adjudicar el arco restaurado sobre el gran arco de ingreso a la Cámara de Doña Sancha (Fig. 5). La diferencia de más de cinco metros de altura entre la nave central ( $\mathrm{H} \mathrm{ca} .12 \mathrm{~m}$ ) y las laterales $(\mathrm{H} 6,8 \mathrm{~m})$ supondría un alto riesgo para la estabilidad del edificio, dificil de asumir por muros que no alcanzan los 0,80 m de grosor ${ }^{19}$. Por ello, el abovedamiento del San Isidoro de este periodo se antoja arriesgado, incluso

\footnotetext{
${ }^{19}$ En San Pedro de Teverga (Asturias), similar en planta al edificio supuesto de San Isidoro, la diferencia entre las dimensiones de las bóvedas de sillería de la nave mayor (L 9, A 2,55, H 9,30 m) y de las laterales (norte L 9,93, A 1,66, H 6,09 m; sur, L 9,87, A 1,64, H 6,09 m) se reduce a 3,20 m y los muros aumentan su grosor a 1,02-1,04 m (medidas según García de Castro 2006: pp. 42 y 45). Sus canecillos fueron relacionados con los del panteón de San Isidoro por Viñayo (1978: p. 228) y Boto (2007: p. 63).
} 
en el caso de adoptar cubiertas de ladrillo. Por lo tanto, aunque la reconstrucción de una estructura abovedada es plausible, la ausencia de indicios deja la puerta abierta a otras posibilidades. Se puede suponer la existencia de un edificio con cubierta de madera, con los aleros laterales descansando al nivel marcado por el tramo de imposta conservado en el tramo norte, sorteando la pareja de óculos por debajo y descansando sus cabezas sobre los muros de la nave central, aproximadamente a la altura de las impostas. La nave central se cubriría del mismo modo. En su caso, la presencia del arco de descarga situado sobre el ingreso a la cámara marca la cota mínima de su altura.

\section{Interpretación y cronología}

El análisis identifica una construcción de tres naves en dirección este-oeste, separadas por pilares, si optamos por una iglesia, o por muros, si es otro tipo de obra. Un vano norte de arco de medio punto peraltado se abría al exterior $^{20}$, mientras otro occidental comunicaba con un espacio cerrado a sus pies, bien sea el panteón u otro ámbito. El muro norte estaba reforzado por contrafuertes no equidistantes que reforzaban un muro que reducía su grosor en altura mediante una serie de escalonamientos. Su anómala disposición difícilmente pudo corresponder a arcos fajones. Aunque su abovedamiento ha sido generalmente aceptado, ya hemos mostrado nuestras dudas. La continuidad del muro conservado obliga a pensar que, de estar abovedado el edificio, las cubiertas, notablemente rebajadas, no se pudieron ayudar de apoyos singulares ni de fajones, los cuales hubiesen sido aún más rebajados. El hecho de que falten los muros sur y este de esta obra, convierte en arriesgado la búsqueda de paralelos ${ }^{21}$.

Respecto a su cronología, la tradicional adscripción a Fernando I y Sancha (1063) no se enfrenta a otros indicios cronológicos desprendidos del análisis estratigráfico. La ausencia de marcas de cantero, propias de la última década del siglo XI en adelante (Moralejo 1996, Alexander 2007 y Esquieu y Hartmann-Virnich 2007) y las cuales aparecen

\footnotetext{
${ }_{20}$ Gómez Moreno (1934: p. 58) opina que esta puerta norte estaba decorada con una pareja de columnas, capiteles y basas entregas, situadas en sus codillos. $\mathrm{Su}$ descripción es seguida por Menéndez Pidal (1964: p. 72, n. 18) en su restauración, pero carecemos de argumentos para confirmar la presencia de estos elementos.

21 Asumiendo que cimientos y alzados son coetáneos, se han sucedido las referencias al aspecto asturiano de esta iglesia, cuyo modelo sería San Salvador de Valdediós (Asturias, Alfonso III 866-910), explicándose dentro de una vinculación con la tradición visigoda y asturiana, lo que resultaría en una iglesia "deliberadamente arcaizante" (Martin 2006: p. 50). Sin embargo, los casi dos siglos que separan ambas obras es un importante obstáculo para entenderla como modelo y para defender la perduración de un estilo que, por otro lado, había sido desplazado precisamente en el territorio de León por aquel denominado "mozárabe" desde inicios del siglo $\mathrm{X}$.
}

de forma numerosa en la obra del periodo inmediatamente posterior, encaja en ese momento. Por otro lado, la pertenencia de las impostas taqueadas a esta fase es clara desde el punto de vista estratigráfico y artístico, estando representadas en la caja de las reliquias de San Juan Bautista y San Pelayo, atribuida a Fernando I y Sancha y datada en el año 1059 (Bango 1997: p. 118). Este elemento arquitectónico y decorativo sería por tanto prácticamente coetáneo a los primeros ejemplos de la catedral de Jaca (Huesca, ¿ca. 1063?), monumento que precisamente le otorga el título de "ajedrezado jaqués". Los otros elementos decorativos son la pareja de capiteles figurados que sujetan el arco de la tribuna y el modillón septentrional ${ }^{22}$.

En nuestra opinión, estos muros serían conservados por razones de pragmatismo, más que por motivos de tributo a los monarcas que los construyeron ${ }^{23}$. Es más, su carácter macizo les permitió aguantar las ruinas de periodos posteriores. Su aplomo indica que tampoco sufrieron ruina en un momento original, sino que fueron desmontados para dar paso a la nueva obra románica, la cual, se engarza en el extremo oriental mediante un suave escalonamiento. La presencia del panteón y la cámara, si no de manera coetánea a esta obra, al menos cuando se produce su desmonte, justificaría igualmente la conservación de estos muros, obligados a permanecer por la existencia de esos espacios. Pero esta es una hipótesis a confirmar.

Finalmente, el hecho de que los muros hallados en excavación estén recorridos por canales de agua, que no se correspondan cimientos, vanos y direcciones de los muros, y que falten contrafuertes en la zona excavada son serios obstáculos para pensar en una única estructura. En nuestra opinión, es más probable la presencia en el lugar de una construcción previa, la excavada (¿romana?), y de otra, la construida, que se superpone a ella aprovechando los cimientos de la primera. La constatación de estructuras romanas en el lugar ${ }^{24}$, como es de prever, dado que estamos intramuros de la ciudad romana, convierte esta posibilidad

\footnotetext{
22 Seehausen (2009: p. 203) subraya la similitud entre ambos (capiteles y modillón), así como con la pareja de capiteles que flanquean la primitiva comunicación occidental entre panteón y aula, y busca el paralelo en los modillones del ábside principal de San Pedro de Jaca. Williams (2011: pp. 105106) rechaza la analogía de los primeros y adopta como paralelos ejemplos más tardíos, ya sobrepasando la década de los 80 del siglo XI.

23 Como subraya Martin (2003: p. 193), que opina que el muro podría haberse disimulado añadiéndole columnas. Seehausen (2009: p. 205) también acepta la intencionalidad de su conservación.

24 Gutiérrez González (1999: p. 59, n. 10) anota la posible existencia de un edificio romano relacionado con el culto del agua, como argumentaría la elección del lugar para construir un nuevo edificio de culto, la presencia de conducciones en las proximidades (García y Bellido 1970: pp. 578-581) y de epígrafes dedicados a las ninfas en la ciudad.
} 
en algo más que probable. Por lo tanto, rechazamos la unidad de los restos hallados en excavación por J. C. Torbado con las UE documentadas en alzado.

\section{Periodo II. Iglesia Románica}

A diferencia de las secuencias tradicionales, las cuales asumen grosso modo la construcción continuada de San Isidoro a lo largo de la segunda mitad del siglo XI y la primera mitad del XII, el análisis arqueológico pone de manifiesto la irrupción de una ruina en el edificio, la cual supone una novedad importante en su conocimiento, con implicaciones en la datación e interpretación de la basílica románica. De este modo, este periodo se secuencia en una etapa constructiva (Periodo IIa), una ruina inmediata (IIb) y una reconstrucción urgente (IIc).

\section{Periodo IIa. Construcción de la Basílica}

[A 102. EU 1000, 1004, 1006, 1012, 1018, $1053,1074,1077,1078,1079,1080,1081$, $1151,1173,1176,1207,1246,1251,1252$, $1264,1284,1323,1371,1372 ;$ A $103 . \mathrm{EU}$ 1085, 1248; A 105. EU 1003; A 168. UE $1145,1146,1147,1148,1209,1224,1225$, 1232, 1240, 1334, 1335, 1359, 1387; A 169. UE 1073, 1075, 1114; A 175. UE 1272]

\section{Análisis arqueológico}

El desmonte de la obra originaría en el ángulo noroeste del aula debió acometerse de manera coetánea a la construcción de la basílica (Periodo IIa), la cual continúa la obra originaria en el testero oeste hacia el sur y en el muro norte hacia el este y amortiza sus vanos occidentales para introducir la arquería norte. La nueva obra superará tanto en extensión como en altura a la primitiva, evidenciando la implantación de un nuevo proyecto completamente distinto y que se mueve en otra escala.

Como es de esperar ante una obra de esta índole, el análisis evidencia que es el resultado de varios grupos de canteros o cuadrillas trabajando al mismo tiempo. ¿Qué elementos permiten reconocerlos? La técnica constructiva de las tres etapas de este periodo es idéntica. Los muros de doble hoja se fabrican en sillería caliza arenosa, dolomía característica de la zona de Boñar (León) y caliza arcillosa, marga que denominan "piedra del país" (Fig. 19). Se dispone principalmente a soga, en hiladas de variadas alturas, pero horizontales y continuas, excepto en aquellos puntos donde hay juntas de obra, reconocibles por la presencia de codos y saltos entre hiladas. Dentro de las hiladas, el empleo de codos es muy escaso y se observan algunos ladrillos verticales $(22 \times 4 \mathrm{~cm})$. Las juntas son estrechas y los sillares se tallan con un hacha aplicada a $45^{\circ}$ (Fig. 12). Esta homogeneidad es alterada únicamente por tres elementos, los cuales ayudan a reconocer los grupos de trabajo (Fig. 20):

1. La ubicación de los mechinales, empleando hiladas bajas que corresponden a su tamaño, o cortando los sillares aprovechando la junta y preferentemente en sus esquinas. Aunque estos huecos puedan parecer elementos distintivos, son unificadores. Aquellos abiertos en hiladas bajas se encuentran principalmente en los

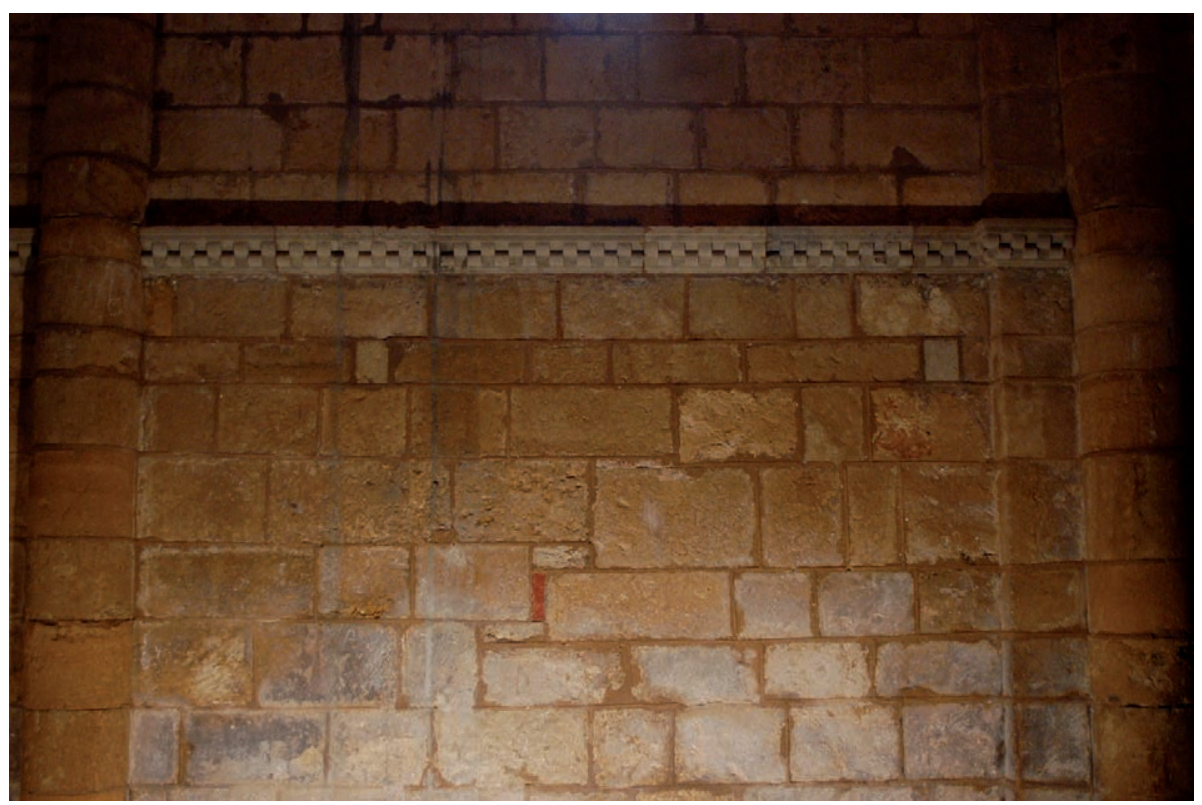

Fig. 19. Detalle de la fábrica del Periodo IIa, segundo tramo occidental del muro sur [UE 1240, A 168], con un encuentro de obra en la zona central (salto de hiladas) 

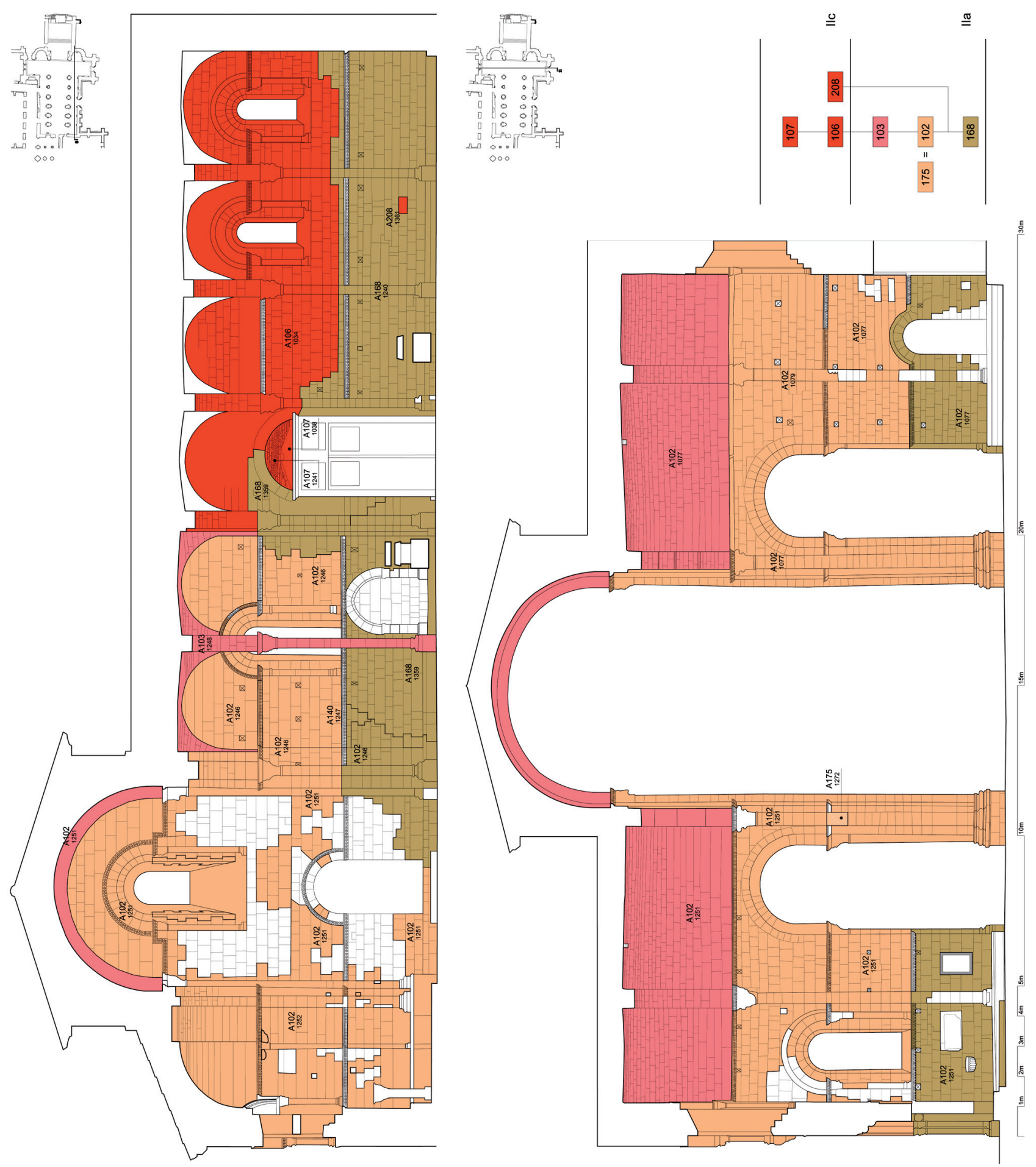

Fig. 20. Planos con la secuencia constructiva del Periodo IIa (la trama de colores corresponde a las Etapas de este periodo), alzado meridional de la nave sur y alzado occidental del transepto 


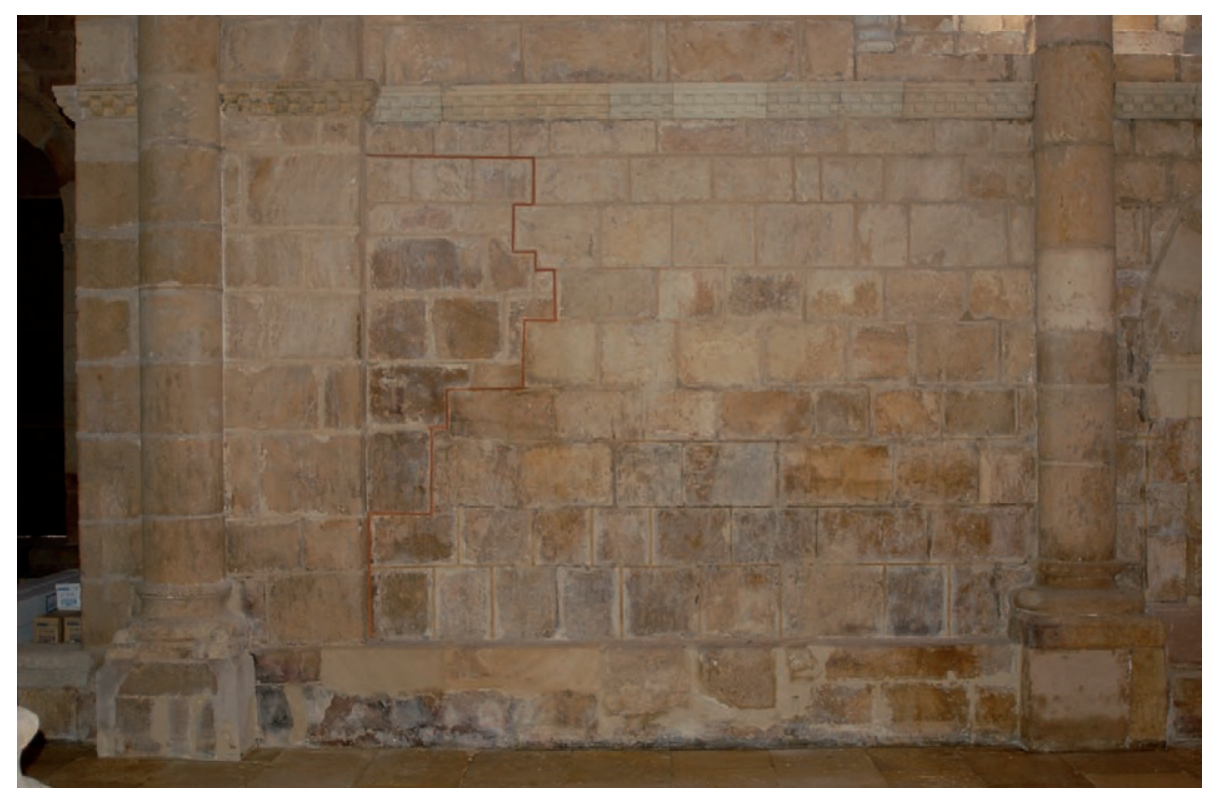

Fig. 21. Junta de encuentro en el extremo oriental del muro sur del aula, marcada en rojo por J. C. Torbado, distinguiendo a la izquierda una obra [UE 1246, A 102] y a la derecha otra [UE 1359, A 168], unificadas a partir de la imposta [UE 1251, A 102]

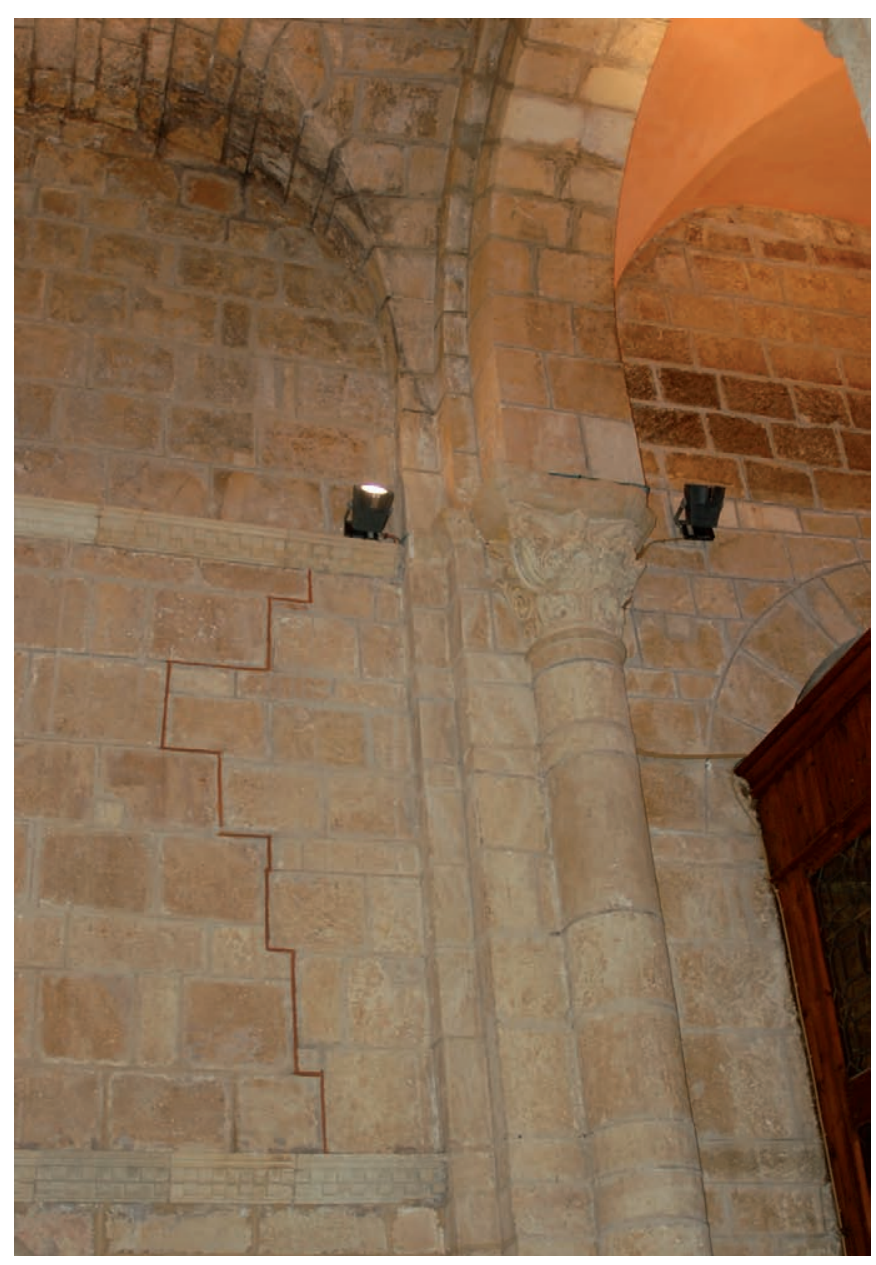

Fig. 22. Junta de encuentro en el muro sur del aula, al este de la puerta del Cordero, marcada en rojo por J. C. Torbado, distinguiendo a la izquierda una obra [UE 1246, A 102] y a la derecha otra [UE 1359, A 168] tramos inferiores, concretamente en los paramentos interiores de los muros sur y norte del aula y en el occidental del brazo sur y norte del transepto (Fig. 20). Estos mechinales se abren siempre en la penúltima o última hilada bajo la imposta taqueada inferior. En los tramos restantes, los mechinales se cortan en las esquinas de los sillares. Estos mechinales no pueden existir sin los anteriores, con los cuales se alinean en vertical, reflejando la posición del andamio empleado.

2. Los saltos de las hiladas horizontales se resuelven mediante el acoplamiento de los sillares con codos y la introducción de otros sillares menores que tapan los huecos generados por los encuentros de obra verticales (Fig. 19). Las impostas funcionan como juntas horizontales "invisibles", disfrazando el cambio y sin los indicios observables en los encuentros verticales.

Por ejemplo, los saltos más evidentes se sitúan bajo la imposta inferior en el extremo occidental del muro sur (Fig. 21) y entre la imposta baja y media junto al vano meridional (Fig. 22). Ambas soluciones de continuidad traban sin embargo obras edilicias idénticas, teniendo mechinales en hilada en el paramento inferior, y cortados en las esquinas en el paramento medio. Estas líneas deben ser entonces entendidas como juntas de obra o de encuentro entre cuadrillas que trabajan en el mismo piso del andamio, viniendo una desde el oeste y otra desde el este. Las puertas de los hastiales del transepto funcionan también como lugares de encuentro, como evidencia la falta de correspondencia entre las hiladas que componen sus dos jambas (Figs. 4 y 23). 


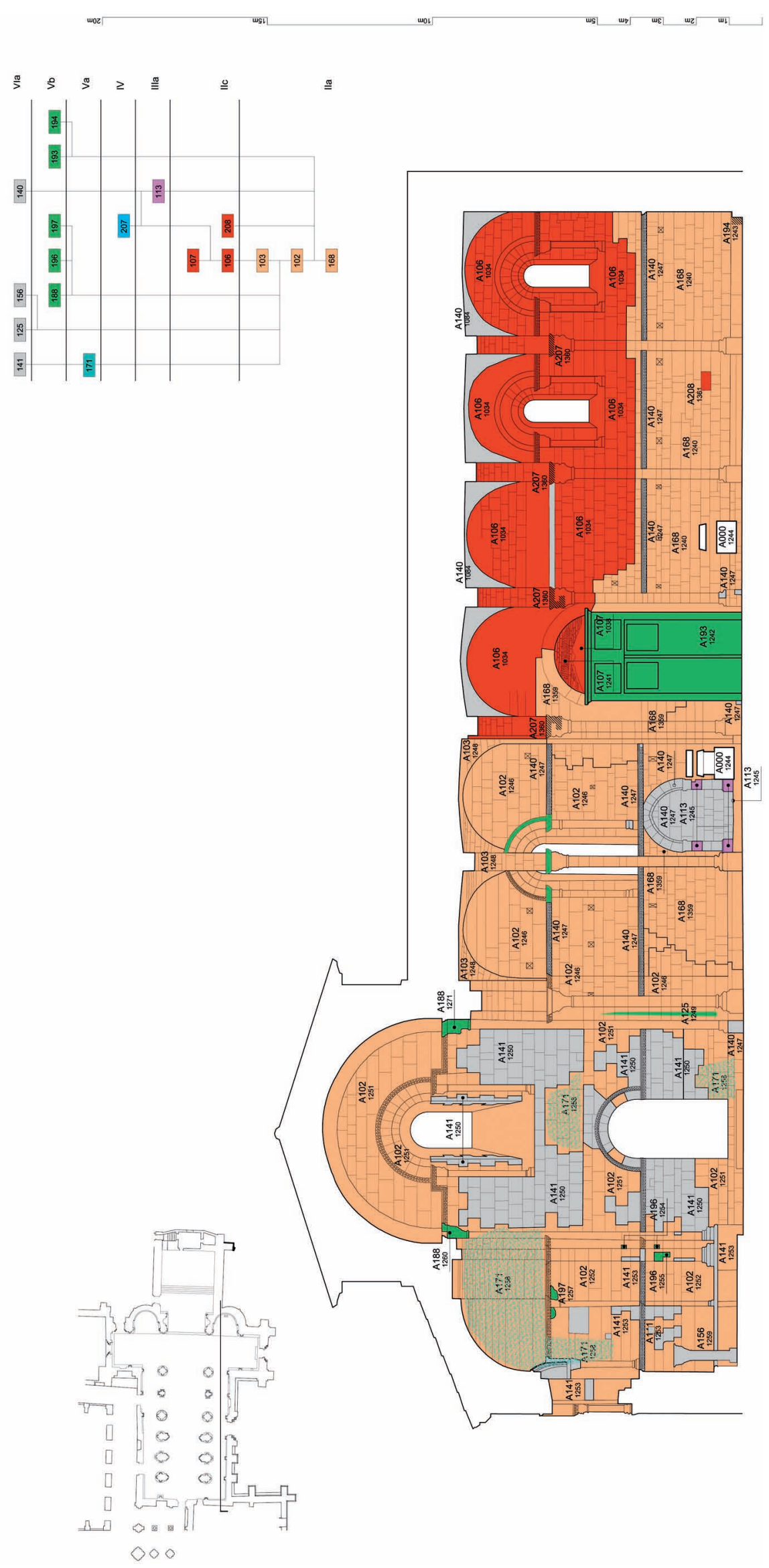


3. Las marcas de cantero aparecen por primera vez en este Periodo IIa. Agrupadas por zonas, reflejan, junto a los aspectos anteriores, el proceso de construcción (Fig. 24), aunque debemos tener en cuenta las limitaciones de su capacidad informativa. Ignoramos si corresponden al trabajo y movimiento de un cantero o de un grupo de ellos; si su asociación por conjuntos tiene un carácter excluyente; si su ausencia tiene, por el contrario, otro significado, teniendo en cuenta la posibilidad de que se hallen además ocultas en los lechos de las piezas, o que hayan sido abrasadas o sustituidas en las restauraciones o eliminadas por procesos naturales de erosión y desgaste. Su tentador uso debe someterse a los principios de la estratigrafía, ofreciendo su análisis resultados complementarios, pero no definitivos por sí mismo. Deben entenderse como un atributo más que contribuye a crear el tipo.

La consideración conjunta de estos tres aspectos (mechinales, saltos de hiladas y marcas de cantero) permite seguir el ritmo de una obra que fue proyectada con aula, transepto y cabecera triple y que no siguió un avance cardinal, sino desde sus cimientos hacia las alturas. Con la intención de explicar de manera clara este proceso, hemos optado por el siguiente esquema.

Etapa 1. Adecuación de los elementos originarios del testero occidental y construcción de la nave meridional. [A 168]. El proyecto comienza con el desmonte del edificio original. La construcción de una basílica mayor implica la prolongación del muro oeste hacia el sur [UE 1232], el alzado de una nueva fachada meridional [UE $1209,1240,1359]$ y la introducción de unas arquerías que sirven a un aula de mayores dimensiones.

Por un lado, las arquerías amortizan los vanos originales del testero oeste, que ahora quedaban descentrados (Fig. 5). El pilar oeste de la arquería norte [UE 1145] cierra así [UE 1224] ambos vanos (Fig. 25). Las fábricas de pilar y del sellado de los vanos son continuas, aunque del superior no podamos asegurarlo por haber sido eliminado por restauraciones posteriores. Por otro, se desmontan los soportes del Periodo I, más próximos entre sí por pertenecer a naves más estrechas. Sus huellas se reconocen por el "chapado" vertical (Periodo IIIb, UE 1216) que recorre el muro oeste (Fig. 5) y parcialmente por la puerta nueva [UE 1225]. Ambos elementos sellarían las jarjas provocadas al retirar los apoyos correspondientes.

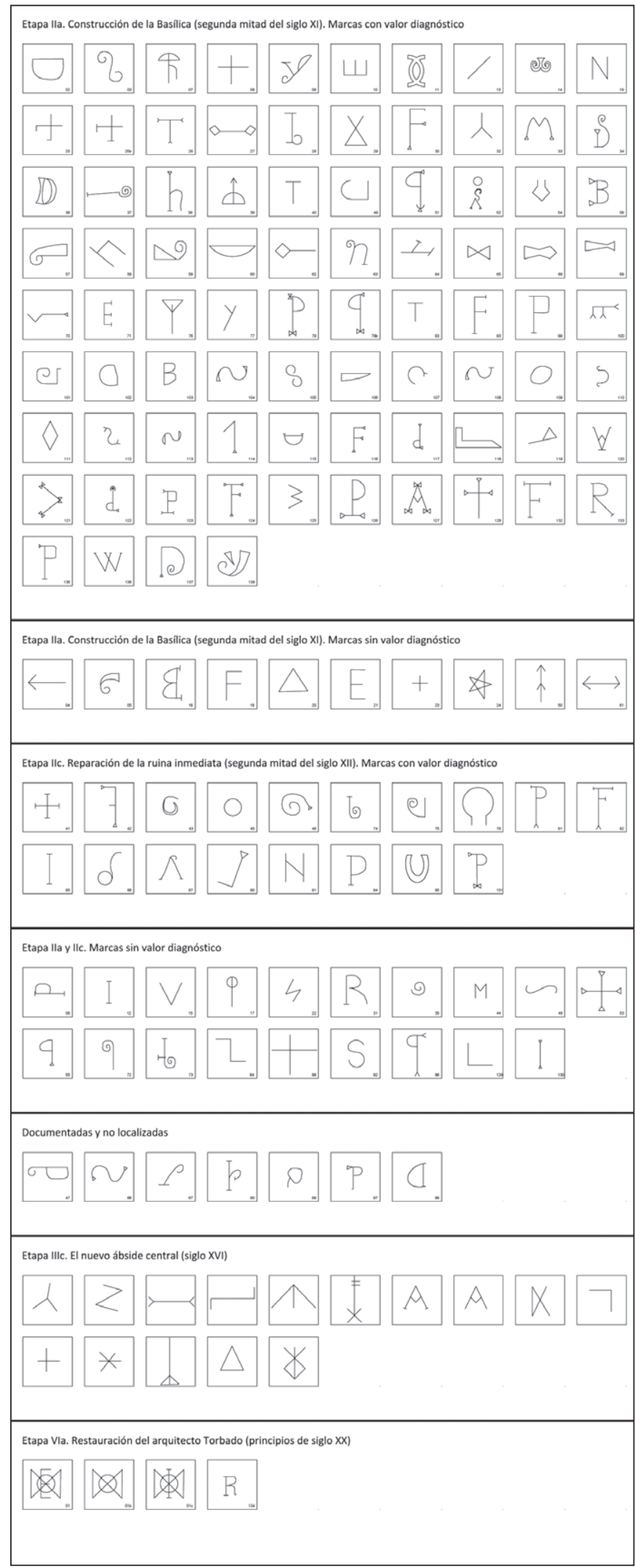

Fig. 24. Síntesis de las marcas de cantero ordenadas por periodos 


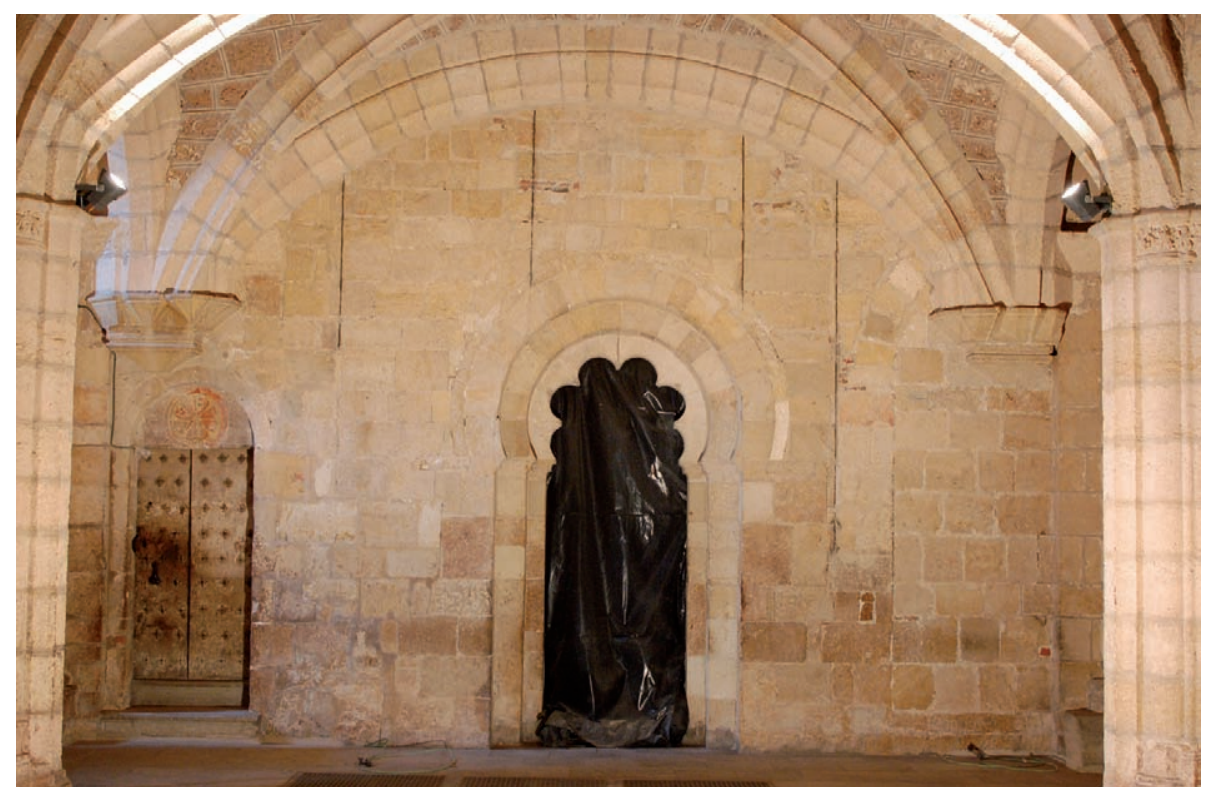

Fig. 25. Paramento oeste de la fachada occidental en la nave central, donde se observa el cierre [UE 1224, A 105] del vano inferior por la construcción de la arquería norte y los nuevos vano central polilobulado [UE 1225, A 105] y meridional con tímpano decorado con un Crismón [UE 1232, A 105], así como las ménsulas y bóveda sobre las que se sustenta el coro occidental [UE 1143, A 110]

Para mantener la comunicación con el panteón, una vez amortizado el vano occidental inferior, se abre otro [UE 1225] más hacia el sur, centrado así respecto al eje del nuevo aula (Figs. 5 y 25). Se dota de tres arcos sucesivos, de este a oeste: un arco de herradura exterior sobre imposta de nacela abrazado por una moldura continua, hoy degollada; un arco intermedio con el mismo perfil y otro inferior polilobulado. La sillería que flanquea este vano se continúa $75 \mathrm{~cm}$ hacia el norte, donde se encuentra con la jamba de la puerta del Periodo I, y 1,05 m hacia el sur, donde lo hace con otros restos de la misma fábrica; y en altura hasta la base del coro, excepto por encima del arco, donde aún se conservan también tres hiladas de la obra primitiva [UE 1215]. El lado oeste del vano, dentro del panteón (Figs. 8 y 26), se salva mediante un arco de medio punto peraltado cuyas jambas se adosan a la fábrica del panteón.

En este lado (Fig. 8) no queremos dejar de hacer referencia a la relación entre las pinturas del panteón [UE 1325] y la apertura de esta puerta [UE 1225]. Aunque a primera vista parece que las pinturas fueron cortadas por este vano ${ }^{25}$, la observación evidencia cómo un estrecho

\footnotetext{
25 Williams (1973: p. 180) indicó que las pinturas de la Natividad fueron mutiladas por la nueva puerta. Opinión seguida por Yarza (1979: p. 205), Fernández González (1992: p. 15 y 2009: p. 52), Walker (2000: p. 200), Martin (2005: p. 378), Sánchez Ameijeiras (2005: p. 490) y Prado-Vilar (2009: p. 221, n. 72). Pérez Llamazares (1927: p. 373) opina que fueron destruidas en la zona de la puerta por obras previas a lo que, en su opinión, corresponde a Fernando II. Uno de los evaluadores del artículo nos pregunta sobre los pigmentos de las pinturas y nos plantea un posible significado del panteón en relación a la iconografía de estas, pero dado que, como se ha indicado (ver nota 11), no hemos realizado el análisis de este espacio, no podemos contestar a estas cuestiones.
}

filo de pintura en el ángulo norte pasa por encima de los sillares que forman su tímpano (Fig. 26). Esta relación confirma la posterioridad de las pinturas, cuya cronología también ha tenido su propio debate (Fig. 1), en el cual no entramos por estar fuera del ámbito de nuestro análisis.

Esta puerta de comunicación con el panteón está acompañada por otra pareja de vanos meridionales en eje vertical [UE 1232], los cuales evidencian de nuevo la presencia de un cuerpo occidental de dos pisos coetáneo. Ambos se ajustan al lado norte de la arquería sur (Fig. 5), situándose así en el espacio de la nave central. El vano inferior se salva con un arco de medio punto de dovelas decoradas en su frente con una incisión perimetral (Fig. 25). El arco encierra un tímpano monolítico con un crismón central, con la alfa y la omega invertidas en su orden, dentro de un círculo perlado. El vano superior vuelve a ser un doble arco de medio punto, alzado sobre jambas rectas y sin imposta en la cara oeste (Fig. 8), y sobre capiteles y fustes en la este, la que da a la nave central. Moldura, impostas y capiteles fueron víctimas del incendio que asoló esta zona (Periodo Va), perdiendo sus decoraciones.

Los tramos correspondientes a la nave central y septentrional de este muro oeste son los únicos carentes de mechinales (Fig. 5), pues seguramente la obra iría rellenando los huecos dejados por el edificio primitivo, como su vano o los desmontes de los muros, instalándose andamios independientes para tal efecto. El tramo meridional [UE 1232] (Fig. 5), por su parte, es nuevo desde sus cimientos por sobrepasar ya el perímetro del edificio del Periodo I. Se alza en sillería caliza sobre un 


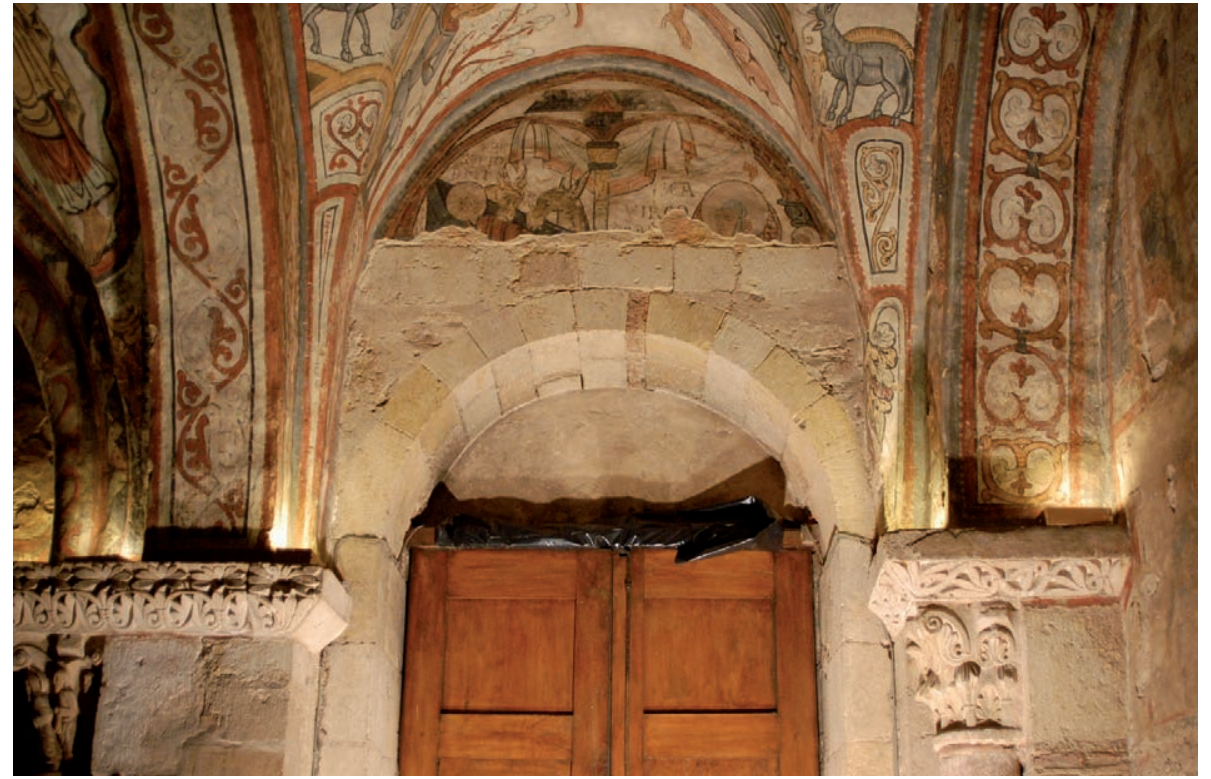

Fig. 26. Detalle de las pinturas del panteón [UE 1325, A 200] y la apertura de la nueva puerta [UE 1225, A 105], observándose cómo un estrecho filo de pintura pasa en el ángulo norte (izquierda) sobre los sillares del tímpano zócalo saliente de dos hiladas y posee mechinales en las hiladas bajas. No se aprecian saltos ni codos y las marcas de cantero no son aquí muy abundantes.

Esta fachada occidental estuvo reforzada por una pareja de contrafuertes (Fig. 8), arrasado posteriormente el meridional, del cual conservamos sus jarjas reparadas en la planta baja [UE 1352] y alta [UE 1348]. El septentrional arranca sobre la cubierta de la cámara de Doña Sancha, sin que podamos reconocer su base oculta por el tejado actual ${ }^{26}$.

De nuevo, el pilar occidental [UE 1232] de la arquería sur adquiere una planta en forma de " $\mathrm{T}$ ", fruto de unir pilar y semicolumna, siendo sus hiladas y las del muro oeste continuas (Fig. 5). Se corona con un capitel corintio doble bajo imposta taqueada. Los cuatro pilares exentos más occidentales de la arquería norte [UE 1146, $1147,1148,1387]$ y de la sur [UE 1334, 1335] se alzan sobre plintos circulares y se componen de tres semicolumnas unitarias con un pilar central. El adosamiento del coro (Periodo IIIb) eliminó las (cuartas) columnas del lado de la nave mayor.

El muro oeste dobla hacia el sur [UE 1240] (Fig. 23). La sillería del muro sur (Fig. 19) se ejecuta de la misma manera, repitiéndose la presencia de mechinales que aprovechan las hiladas bajas hasta la imposta baja, $\mathrm{y}$ manteniéndose el zócalo (H $38 \mathrm{~cm}$ ) hasta la jamba oeste

\footnotetext{
${ }^{26}$ Carecemos de planimetría adecuada para el estudio y contraste de medidas de esta zona. Los elementos y líneas perimetrales se han situado en el plano según los datos tomados en la lectura de campo a partir del alzado publicado por Williams (2008).
}

de la portada. Unas semicolumnas marcan los tramos abovedados: mientras la más occidental es solidaria con un semipilar y con el muro, siendo sus hiladas continuas, las dos orientales lo hacen directamente con el muro. Este alzado se conserva hasta una hilada por encima de la imposta baja taqueada, pues la ruina sufrida por el edificio (Periodo IIb) arrastró su parte alta.

De hecho, esta ruina se refleja especialmente en la portada de la fachada sur [UE 1240, 1359] (Fig. 27). Se compone de tres vanos arcuados concéntricos, el central de medio punto apeado al exterior en machones prismáticos y los otros dos arcos en columnas. De estos elementos, son originales los machones situados detrás de las columnas [UE 1209, A 168], con huellas de talla de puntero. El resto de la portada es fruto de la reconstrucción del Periodo IIc.

Etapa 2. Avance de la obra hacia el este. [A 102 y 105]. Al este de la puerta (Fig. 23), el muro sur [UE 1359] continúa empleando semicolumnas. Sin embargo, nos encontramos ya con el primer cambio evidenciado en la disposición de los mechinales y en la presencia de juntas de obra. El tramo inferior del muro, bajo la imposta baja, se realiza con la ayuda de andamios que se sirven de hiladas bajas para introducir las agujas (Figs. 19 y 21). Esta manera de hacer recorre los frentes occidental y meridional del brazo sur del transepto hasta la puerta, por un lado, y todo el meridional de la nave, por otro (Fig. 20). El encuentro entre las dos cuadrillas que están construyendo estos muros se da junto al extremo oriental, precisamente donde el muro gira hacia el 


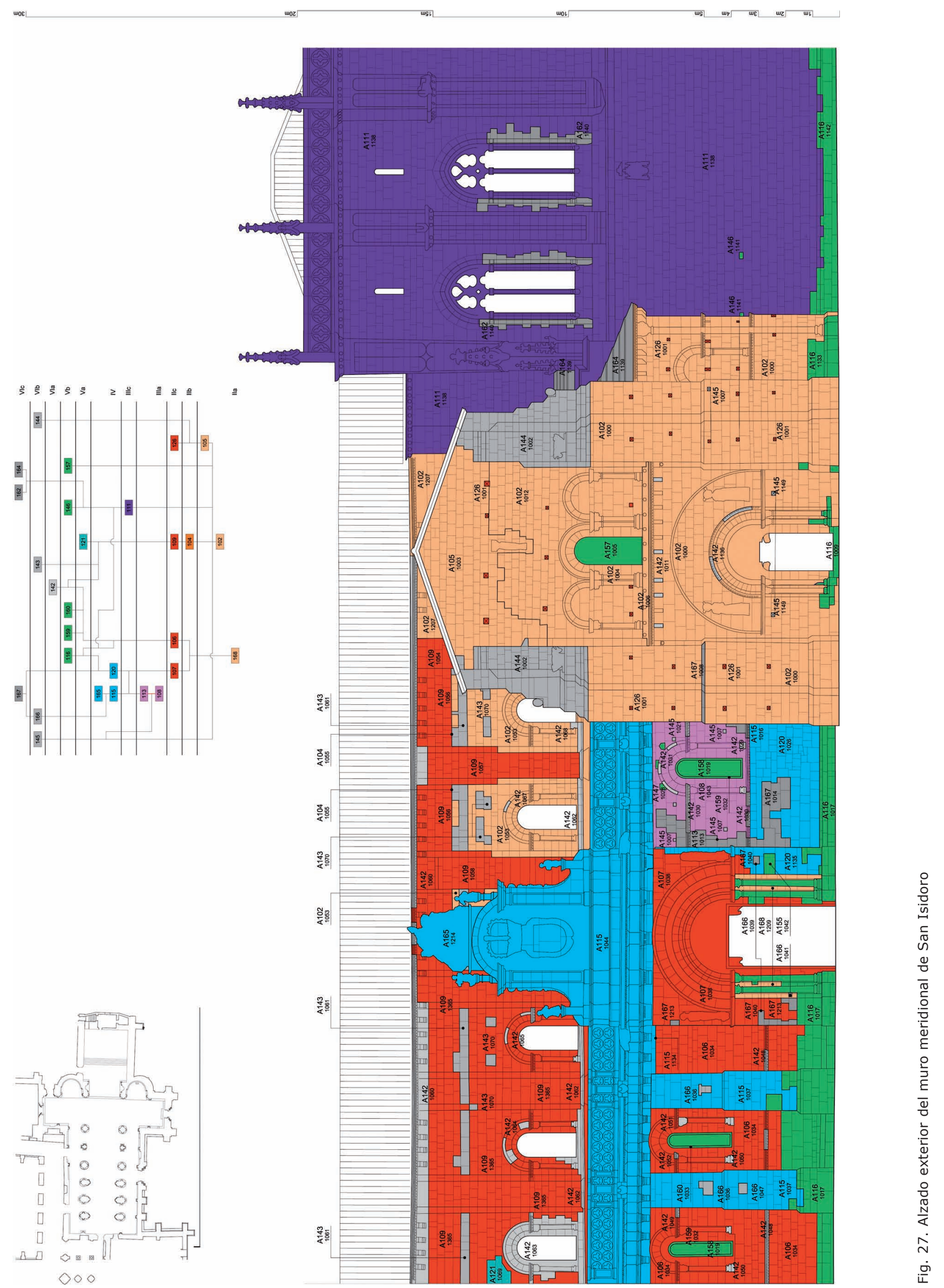




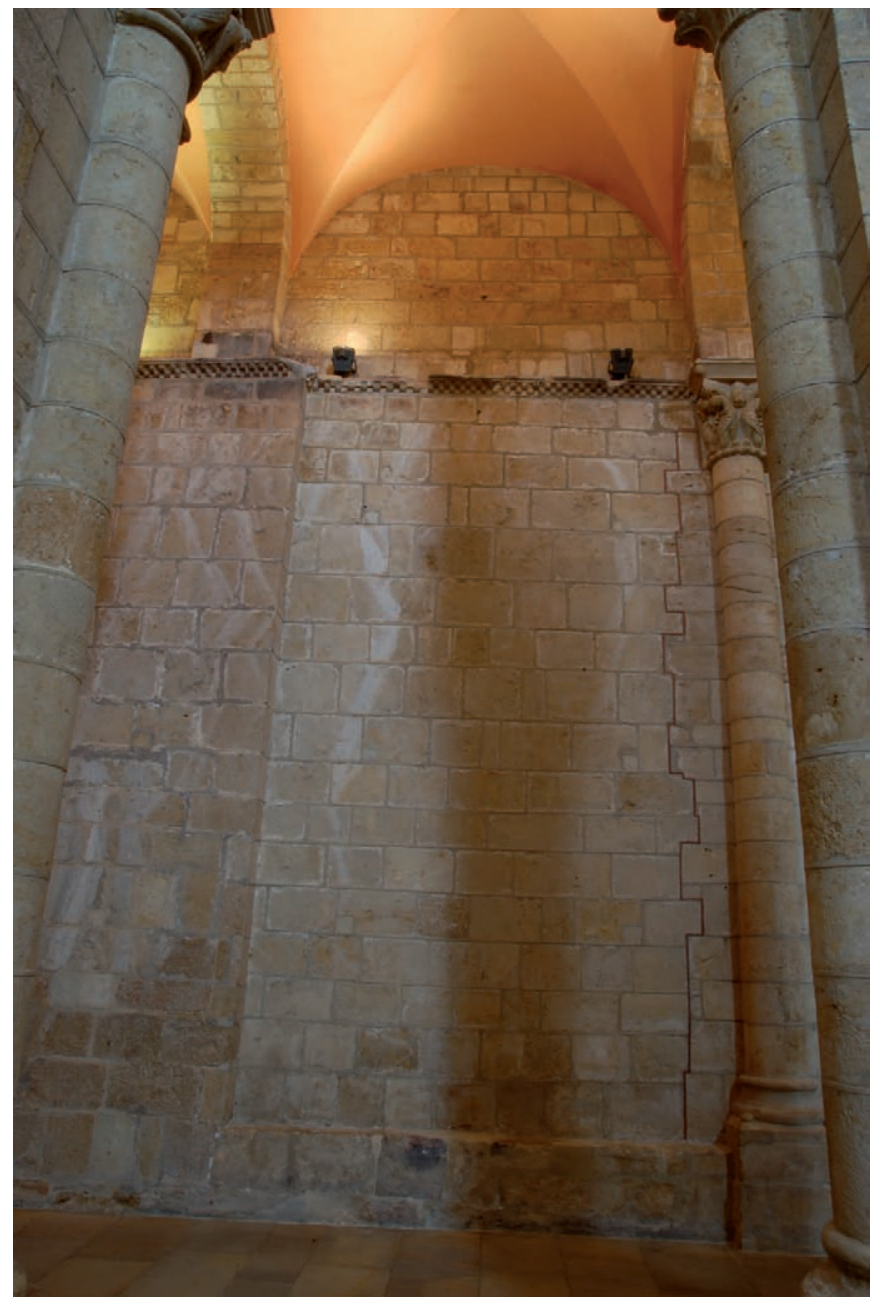

Fig. 28. Lienzo interior de la nave norte [UE 1075, A 169] con los mechinales pasantes y solución de continuidad [UE 1074, A 102] en el tercer tramo

sur, evidenciándose la construcción coetánea de ambos tramos, apoyándose el oriental sobre el occidental de acuerdo a la inclinación de la junta (Fig. 21) ${ }^{27}$. A ambos lados de la junta identificamos además dos grupos distintos de marcas: muro oeste del transepto [UE 1246, 1251] (Fig. 20): 3, 4, 5, 6, 7, 13; muro sur de la nave [UE 1359] (Fig. 23): 4, 15, 20, 21, 22, 23, 83, 84 ${ }^{28}$.

El mismo ritmo se observa en la mitad norte del edificio: muro oeste del transepto [UE 1077] (Fig. 20): 4, 22, con un número menor de marcas debido al desgaste efecto del incendio; y muro norte de la nave

\footnotetext{
27 La remarcación en rojo por J. C. Torbado de esta junta es engañosa, pues la penúltima hilada bajo la imposta es continua en todo el tramo, estando en realidad descoordinada con el pilar. La última hilada bajo la imposta recorre tanto este tramo del muro sur del aula como el oeste del transepto.

28 Números correspondientes a los empleados en las tablas que representan las marcas de canteros.
}

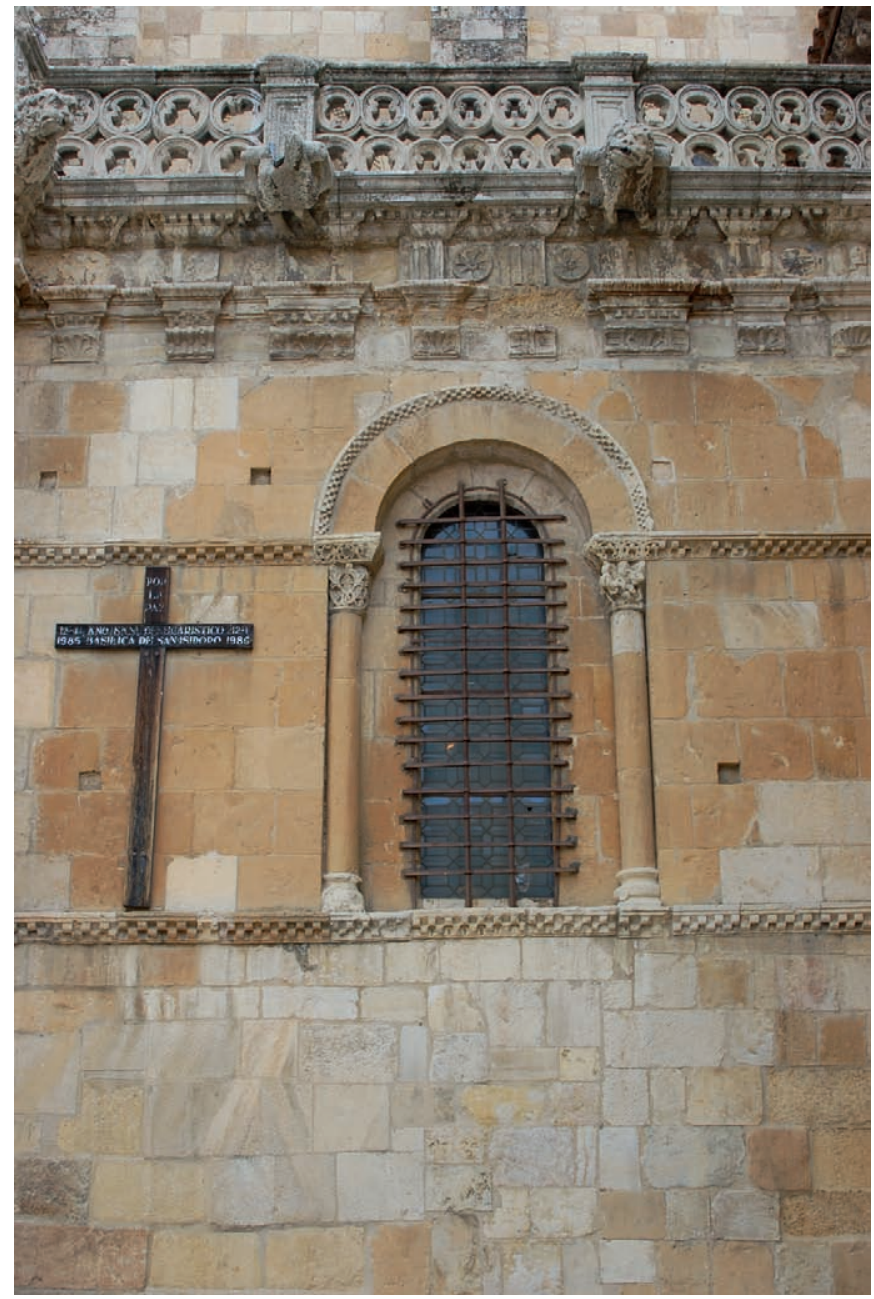

Fig. 29. Paramento exterior del muro sur [UE 1359, A 168], aplacado en parte inferior [UE 1026, A 120] y mechinales de los apuntalamientos de la ruina [UE 1001, A 126] en la superior

[UE 1074] (Fig. 4): 4, 21, 22, 23. A diferencia de los correspondientes alzados meridionales, aquí no hallamos junta en la esquina nave-transepto, siendo el muro oeste del transepto, desde la jamba sur del vano oeste, y el lienzo de la nave norte continuos. Es este lienzo norte [UE 1074] (Fig. 4) el que muestra una solución de continuidad casi vertical (Fig. 28) que discurre por el lado occidental de la tercera columna adosada, formando una "cremallera" que, a diferencia de los anteriores saltos, sí refleja una nueva fase de obra, pues va acompañado de otros aspectos que posteriormente resaltaremos.

Las marcas de los muros norte y sur del aula coinciden con los occidentales del transepto, validándose la unidad de aula y transepto. El paramento exterior del muro sur [UE 1359], muy alterado por actuaciones posteriores, ha perdido casi toda su superficie original, por lo que desconocemos sus posibles marcas (Figs. 27 y 29). 
En aula y transepto, la imposta baja marca el cambio hacia la obra con mechinales tallados en las esquinas de los sillares (Fig. 20). Su alineación coincide con los inferiores, confirmándose el entramado de andamios que servían a la construcción. De nuevo, los saltos y las marcas avalan la coetaneidad de la construcción. En la nave sur, la junta o salto en las hiladas del tramo de muro comprendido entre las impostas se sitúa al este de la parte media de la semicolumna que flanquea la puerta (Fig. 22). Mientras del oeste apenas podemos aportar datos, por haberse perdido en la ruina posterior (Periodo IIb), del este contamos con las marcas 4, 5, 12, 13, 16, 49, 70, 71, continuándose parte de ellas en el paramento correspondiente ya al muro oeste del transepto: 5, 6, 7, 11, 12, 16. En el paramento medio del muro oeste del brazo norte del transepto se observan las marcas 4,15 y 23 , continuándose hacia la nave con 13, 20, 22 y 55 .

Tanto en la nave sur (Fig. 23) como en la norte (Fig. 4), en los tímpanos de las bóvedas, es decir, en la parte superior del muro sobre la imposta alta, se reducen las marcas, prácticamente ausentes en el sur (4) y mínimas en el norte (18, 68 y 69). Las bóvedas tienen en común la marca 12 , presente también en los muros del transepto ${ }^{29}$.

La disposición de mechinales cortando las esquinas de los sillares marcará el devenir del resto del edificio, por lo que parece que la obra que aprovechaba las hiladas bajas para anclar sus andamios se limita prácticamente a la parte baja. Es posible que, una vez en marcha, se complique el ajuste de hiladas y mechinales, los cuales pasan a cortar los sillares. La obra avanza por todo el extremo oriental del aula, el transepto y la cabecera. Se efectúa de manera unitaria, empezando por los cuerpos inferiores hasta abovedar los ábsides laterales, aunque no quedará cerrada por completo en la nave norte. Incluimos en esta etapa los pilares orientales de ambas arquerías y el cuerpo de ventanas superior.

Las únicas ventanas (Fig. 30) de las naves laterales se encuentran precisamente en estos tramos orientales [sur UE 1246, norte UE 1074]. Ambas se ajustan en el interior a la imposta baja del muro y hacen coincidir el arranque de su arquivolta con la imposta media. $\mathrm{Su}$ sección es simétrica, mostrando tres jambas escalonadas que acogen órdenes de basas, fustes y capiteles en sus frentes. Al exterior, la norte fue restaurada por Torbado [UE 1127] (Fig. 6) y la sur alterada por el adosamiento

\footnotetext{
29 Las cubiertas abovedadas así como los tramos altos de los muros fueron observados con prismáticos desde el suelo, por lo que no podemos descartar la presencia de un mayor número de marcas.
}

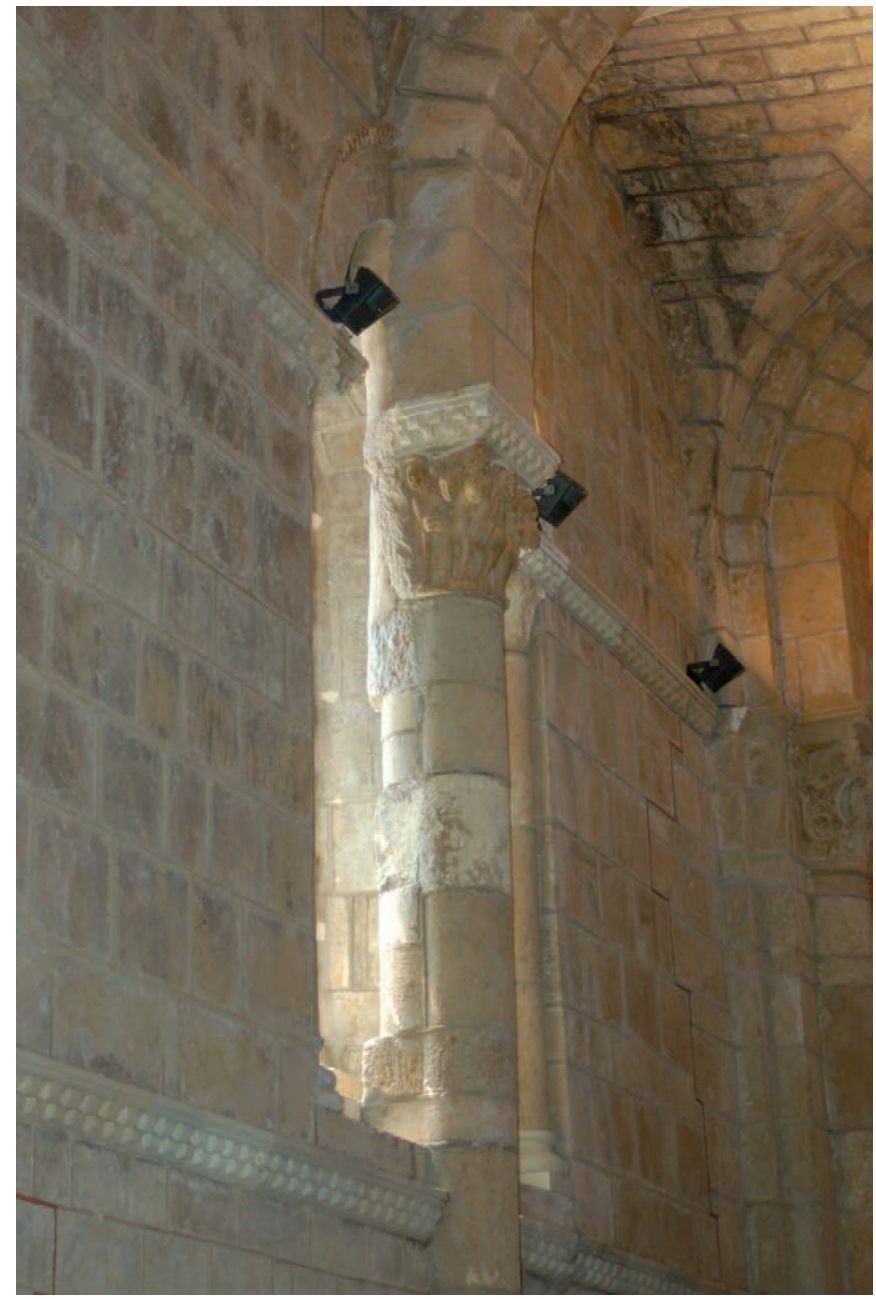

Fig. 30. Detalle de la columna [UE 1248, A 103] coetánea al tapiado de la ventana oriental del muro sur del aula [UE 1246, A 102], con el frente posterior de los tambores, capitel y arranque de la bóveda inacabado

de una capilla gótica (Fig. 27) y la posterior restauración de su desmonte [UE 1030], aunque puede apreciarse aún su forma original (Fig. 29).

El transepto presenta una altura y anchura similares a la nave central, aunque la longitud de sus brazos es proporcionalmente mucho más corta. Sus frentes meridional [UE 1000, 1012], septentrional [UE 1077] y longitudinales [UE 1251, 1077] se alzan en la fábrica propia de este periodo: sillería dispuesta en hiladas horizontales que alternan sogas y tizones tallados con un hacha aplicada a $45^{\circ}$ y unidas con juntas finas. Las marcas de cantero están presentes en todo el alzado, aunque el incendio interior (Periodo V) y la erosión exterior dificultan su identificación. Al brazo meridional se accede por una portada, conocida tradicionalmente como la Puerta del Perdón (Figs. 27 y 31). Dos arcos de medio punto concéntricos encierran un tímpano decorado con 


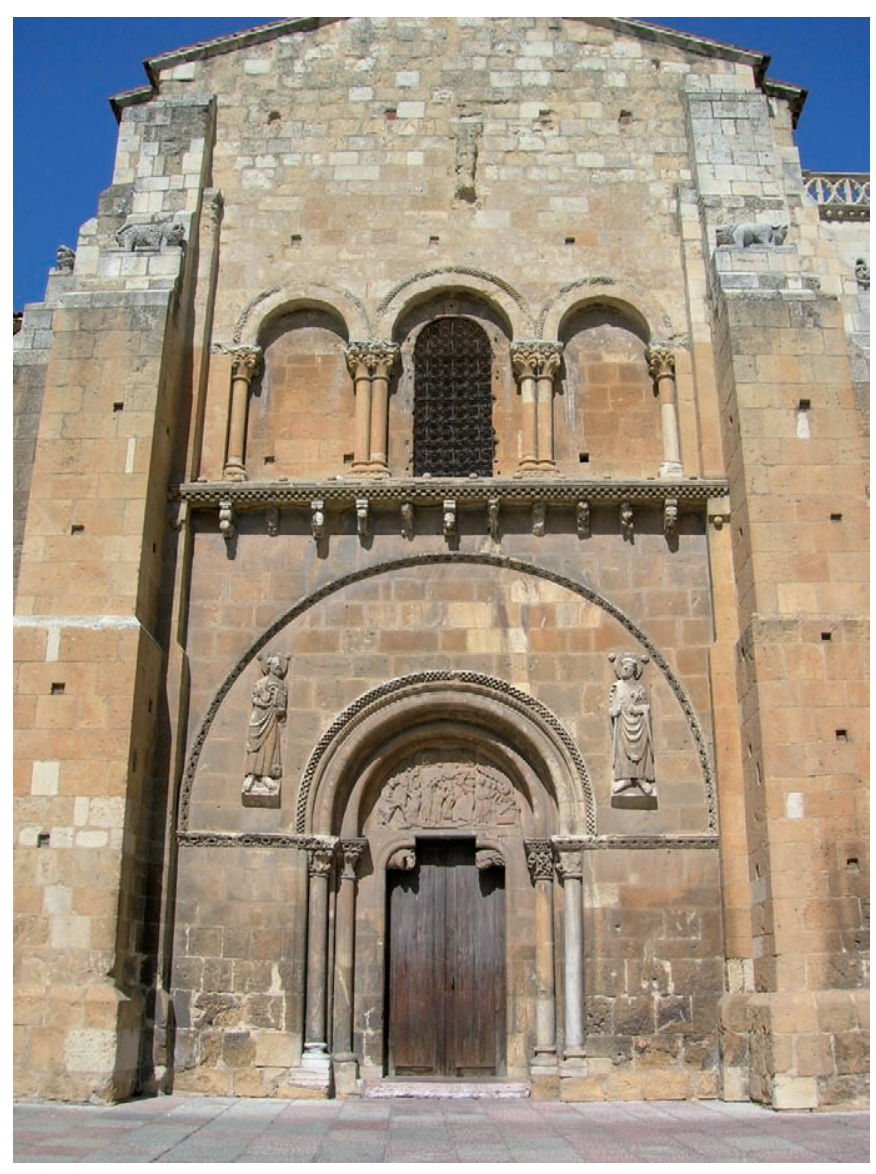

Fig. 31. Fachada meridional del transepto con la Puerta del Perdón [A 102] y serie de mechinales correspondientes a los apuntalamientos de la ruina [UE 1001, A 126]

tres placas, en las que se tallan la "Resurrección", el "Descendimiento" y la "Ascensión de Cristo". Este conjunto descansa sobre una imposta continua y dos parejas de columnas. El vano está flanqueado por dos figuras ("San Pablo" y "San Pedro") encerrados por un último arco-imposta. Este grupo decorativo estaría rematado por una figura de "San Isidoro" en lo alto del tímpano del muro del transepto, hoy tan erosionada que es difícil de reconocer ${ }^{30}$.

Aunque el segundo cuerpo de la fachada sur del transepto [UE 1012] presenta un cambio de material, la identidad técnica de su fábrica y la ausencia de cortes confirman su pertenencia a una misma obra (Fig. 27). El cambio de dolomita naranja a otra de tono más claro debe buscarse en la variación de la fuente de aprovisionamiento, pero no en la identificación de otro momento constructivo (Fig. 31). Superada una imposta taqueada con modillones y otra de más sencilla factura con bolas

\footnotetext{
30 Descrita por Díaz-Jiménez (1917: p. 82), quien aún pudo verla.
}

[UE 1006] tallada en una piedra más clara, un juego de tres arcos decora su frente, siendo ciegos los laterales y abierto a modo de ventana el central. Tanto esta [UE 1004] como la ventana occidental [UE 1018] de este mismo brazo meridional conservan los anclajes de las rejas primitivas que las protegían. El remate exterior, de sillares ligeramente menores [UE 1003, A 105], es posiblemente un muro de única hoja que cierra el transepto y sujeta la bóveda de cañón. El hecho de que esté fuertemente desgastado impide añadir detalles descriptivos sobre su fábrica. La lectura del interior no identifica soluciones de continuidad con la parte interior, lo que confirma su originalidad.

A diferencia de la fachada sur del transepto, la septentrional [UE 1077] (Fig. 6), hoy oculta por la Capilla de los Quiñones, prescinde de los tres vanos y abre únicamente el de la ventana. La portada repite el esquema de dos arcos e imposta exterior de la meridional ${ }^{31}$.

Los mechinales en las esquinas de los sillares se observan en los lienzos interiores [UE 1251 sur, 1077 norte]. El brazo norte del transepto (Fig. 20) comunica con el claustro mediante un vano de arco de medio punto y jambas continuas salvado por la imposta taqueada inferior que recorre todo el transepto. La imposta se reproduce en tres niveles en los muros longitudinales del transepto, estando ausente el central en los testeros (Figs. 4 y 23).

Ambos brazos del transepto (Fig. 20) se organizan en dos tramos diferenciados por arcos fajones [norte UE 1079, 1080, 1081] que descansan sobre columnas adosadas asentadas sobre el zócalo perimetral con baquetón. La longitud de los tramos próximos a la nave central corresponde a la luz de los ábsides laterales, siendo por ello más anchos que los extremos iluminados por ventanas de medio punto que, como las de los ábsides, superan la imposta media y respetan la inferior. Los arcos fajones son correspondidos al exterior por pequeños y estrechos contrafuertes [UE 1284 norte, 1012 sur] en los muros longitudinales. Los contrafuertes nacen aproximadamente a la altura de la imposta alta interior, sobre la que arranca la bóveda, permitiendo la transición hacia unos paramentos más estrechos a una altura donde las bóvedas pueden prescindir del grosor inferior de los muros. El refuerzo de los muros se completa con dobles juegos de gruesos contrafuertes en las esquinas.

\footnotetext{
31 Documentado su estado por Gómez Moreno (1925). Martin (2008c) propone una reconstrucción de la composición escultórica de esta portada a partir de distintos fragmentos depositados en el claustro.
} 

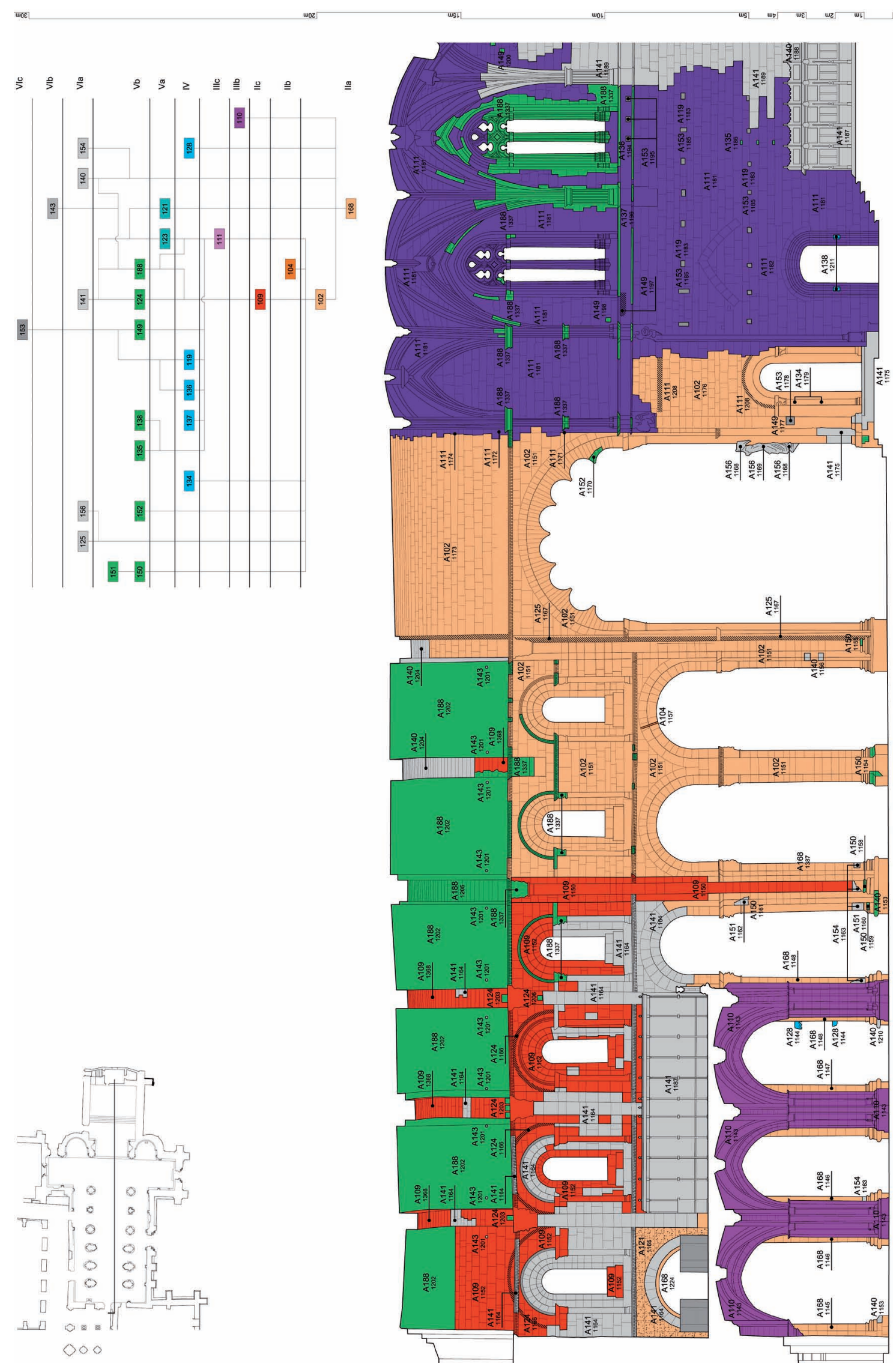
Delimitado por dos fajones polibulados al norte [UE 1151] y al sur [UE 1207], el crucero se aboveda con una forma de medio cañón [UE 1173] en eje con las bóvedas de la nave central (Fig. 32). Otro arco fajón, en este caso de medio punto, arranca de la imposta alta, dando el paso a las bóvedas de la nave central elevadas a la misma altura. Alzada en hiladas horizontales y marcada con signos de cantero, desconocemos el enganche de la bóveda del crucero con la del ábside primitivo, al haber sido cortado por la cabecera gótica (Periodo IIIc).

El arco polibulado norte [UE 1151] se alza de manera solidaria con la arquería, incluido hasta el tercer pilar con sus dos arcos de medio punto peraltados (Fig. 32). De nuevo, una imposta taqueada marca el paso al cuerpo del muro donde se abren dos ventanas de medio punto sobre parejas de columnas e impostas propias. El resto del muro alto, del mismo modo que ocurre en el lado meridional, se arruinó, perteneciendo la obra actual a una reparación posterior (Periodo IIc). Al exterior (Fig. 6), únicamente el vano más oriental y el muro que continúa el arco polilobulado [UE 1371], acompañado por estrechos contrafuertes, y la parte inferior del primer contrafuerte de la nave [UE 1372], visible sobre la cubierta lateral, se han conservado íntegramente. Del mismo modo, el arco polilobulado sur [UE 1207] se alza junto con la arquería meridional [UE 1053] que, como la septentrional, alcanza hasta el tercer pilar, repitiéndose el esquema de arcos peraltados, imposta y ventanas altas con imposta propia.

La nave central se levanta sobre una arquería de pilares compuesta por arcos doblados y peraltados (Fig. 32). Los cuatro arcos occidentales tienen una luz ligeramente menor que los dos orientales. Esta diferencia se mantiene también en las ventanas superiores, unidas por una imposta continua y de mayores dimensiones que sus compañeras occidentales. Aunque estas sean ahora el fruto de la restauración posterior (Periodo IIc), debemos suponer que mantienen el mismo ritmo que las originales. Otra diferencia singular de esta zona es que, a diferencia de los cuatro tramos occidentales de la nave mayor, aquí se prescinde de la columna semiadosada que recorre el muro en toda su altura, por lo que el arco fajón de la bóveda se ve obligado a arrancar de una ménsula independiente.

La misma constante de mechinales cortados en las esquinas de los sillares se observa en los muros interiores de los dos ábsides conservados: el septentrional [UE 1078] y el meridional [UE 1252], ornamentados con zócalos con baquetón y columnas semiadosadas.

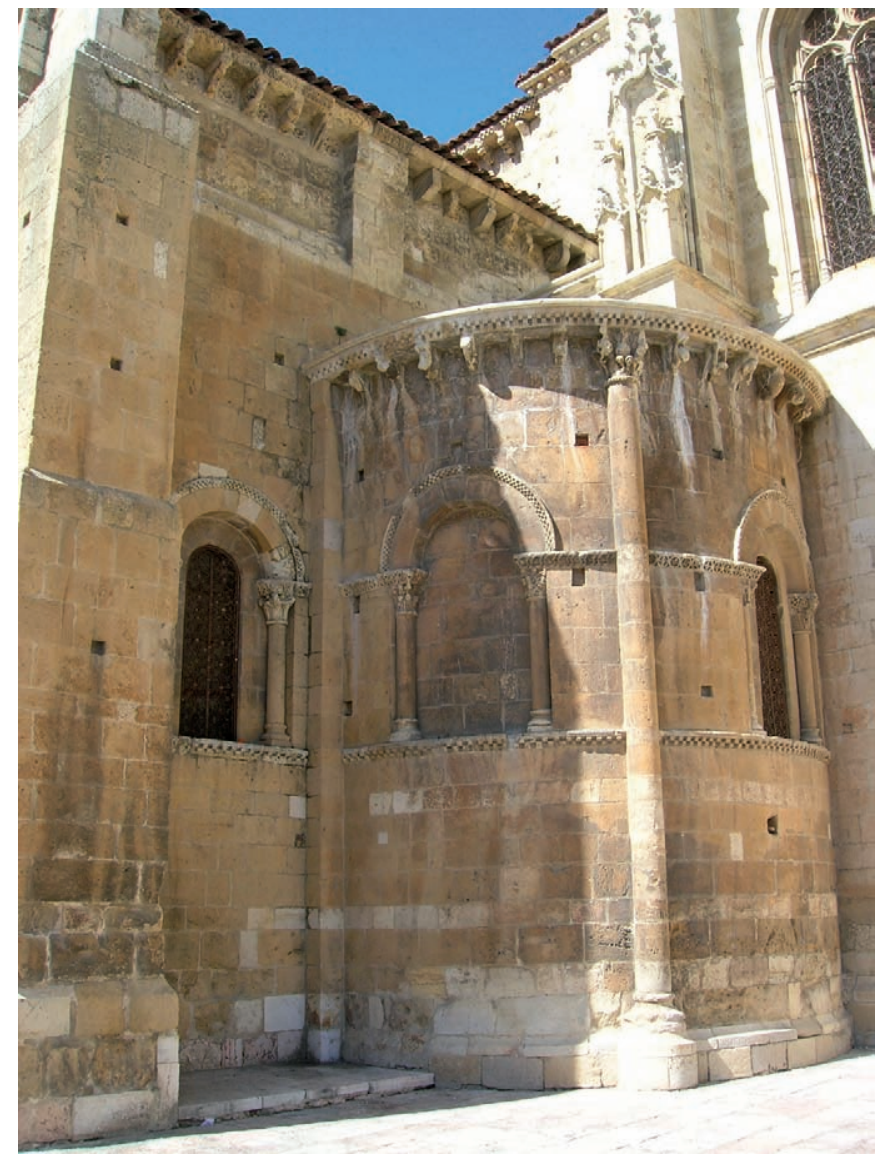

Fig. 33. Exterior del ábside meridional [UE 1000, A 102] y mechinales correspondientes a los apuntalamientos de la ruina [UE 1001, A 126]

Ambos poseen una mitad oriental con planta de medio punto rebajado y otra menor occidental recta. Estas dos partes se traducen en altura en una bóveda de cuarto de esfera, una bóveda de medio cañón y un arco fajón sobre pilastras, todo ello en sillería. Se iluminan con ventanas centrales de medio punto abocinadas que superan la imposta taqueada superior y respetan la inferior. Al exterior [UE 1000], zócalo, doble línea de impostas y columnas semiadosadas repiten el modelo interior (Fig. 27). Las columnas sirven además a la división en tres calles, en las que se sitúan las ventanas centrales abiertas y laterales ciegas (Fig. 33), estas no reflejadas al interior. Los exteriores se rematan con canecillos decorados bajo una imposta ajedrezada, como en el resto del edificio. El ábside norte está parcialmente oculto por la Capilla de la Santísima Trinidad adosada en su flanco nordeste (Fig. 34).

Del ábside central, suplantado por la gran cabecera gótica, conservamos únicamente la embocadura recta en el interior [UE 1176] hasta una altura aproximada de 


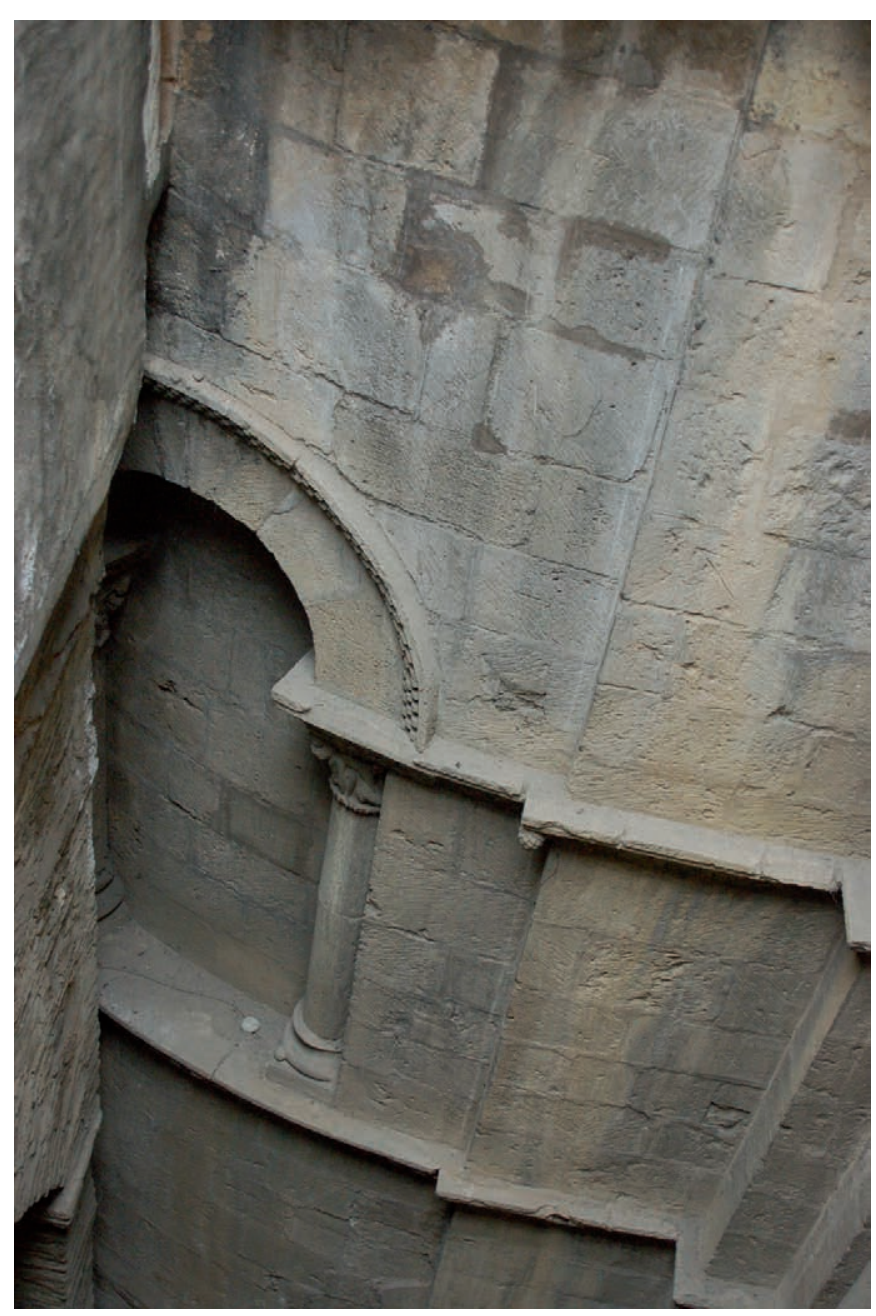

Fig. 34. Exterior del ábside septentrional, detalle del tramo norte al cual se adosa la Capilla de la Santísima Trinidad [UE 1078, A 102]

$8,50 \mathrm{~m}$. Tanto en el paramento norte (Fig. 32) como en el sur se abre un arco ciego sobre el zócalo con baquetón. Este tramo recto y los vestigios documentados en el subsuelo permiten afirmar que su planta era como la de los ábsides laterales conservados (Díaz-Jiménez 1917: p. 83). Las arquivoltas que adornaban estos arcos y la imposta media del paramento fueron degolladas con posterioridad (Periodo III), por lo que desconocemos sus motivos decorativos.

Etapa 3. Cierre de la nave norte y abovedamiento del templo. [A 103, A 169 y A 175]. La obra románica termina cuando se cierra la nave norte [A 169; UE 1073, 1075, 1114] (Fig. 4). Se realiza un lienzo de sillería [UE 1075] de hiladas horizontales, misma talla y materiales, con los mismos mechinales en las esquinas, que rellena el hueco dejado por el desmonte de la obra del Periodo I
[UE 1073] y la nueva obra de la Etapa 2 de este Periodo IIa [UE 1074].

Dos elementos hacen atribuir este muro a una etapa algo posterior. Aunque sus mechinales cortan las esquinas de los sillares, son sin embargo pasantes, perforando el muro y siendo así visibles al interior (Figs. 4 y 28) y exterior (Fig. 6). Segundo, fueron tallados por un andamio distinto, como evidencia el hecho de que la altura de sus pisos no coincida con la del andamio utilizado para construir los dos tramos orientales de la misma nave. La ausencia de imposta baja y la citada "cremallera" (Fig. 28) confirman su pertenencia a otro momento. La presencia de una marca distinta, una "R" (marca 31) de gran tamaño, hizo pensar en la introducción de sillares de restauración [UE 1114], pero una vez realizado el análisis, entendidas las marcas de cantero e identificadas aquellas correspondientes a las obras de restauración modernas y contemporáneas, debemos aceptar que pertenece a este Periodo IIa.

El nuevo muro septentrional incluye, por tanto, la parte occidental del Periodo I [UE 1071], la parte oriental de la segunda etapa del Periodo IIa [UE 1074] y la parte central de esta tercera etapa del Periodo IIa [UE 1075], reforzándose al exterior (Fig. 6) por unos arcos adosados [UE 1323] que reaprovechan los contrafuertes del Periodo I. Restaurados casi en su totalidad por Menéndez Pidal (Periodo VI), estos arcos tenían como cometido igualar el ancho del nuevo muro que desde el este viene a encontrarse con el de menor espesor del Periodo I. Estos arcos tenían pinturas, cuyos exiguos restos de tonalidades rojizas se han conservado en los ángulos entre las dovelas de los arcos y las superficies de los muros.

La anómala disposición de la penúltima pareja de pilares [UE 1085, 1248; A 103] adosados a los muros de las naves laterales (Figs. 4, 23 y 30), delante de las ventanas, no deja de sorprender, pero la lectura confirma que ambos pilares se realizaron de manera coetánea a las fábricas que tapiaban los vanos de luz, como evidencia la superficie irregular de la cara posterior de los tambores de las columnas (Fig. 30), y que fueron concebidos para soportar las bóvedas de aristas [A 103]. Las columnas adosadas a los pilares de las arquerías implican tanto la construcción de un zócalo propio como el adosamiento de sus medios tambores. En la norte, la limpieza de las superficies en 2008 permitió constatar que el fuste se compone de dos piezas de mármol blanco reutilizadas.

Pero tal vez debamos afrontar esta anomalía de la manera contraria y considerar que esta reside en la si- 
tuación de la ventana. Tanto la altura de los arcos de las arquerías, notablemente peraltados, como de la misma ventana del muro hubiesen forzado a situar el arranque de una hipotética bóveda de cañón longitudinal ${ }^{32}$ por encima de la clave de estos, de lo contrario, como demuestra el arco diafragma actual, no podrían convivir. Esta solución habría forzado igualmente a elevar la altura de los muros de la nave central que montan sobre la arquería para poder abrir los correspondientes vanos de luz en ellos. Es decir, se tendría que haber remodulado todo el edificio en altura, lo que implica asumir un riesgo aún mayor en la absorción de los empujes originados por la cubierta abovedada de la nave central.

Una segunda posibilidad hubiese sido plantear bóvedas de aristas, como las actuales, pero con una planta rectangular correspondiente a dos tramos o arcos de la arquería, lo que hubiese dado un total de tres bóvedas en cada nave lateral. Esta solución hubiese permitido reducir el número de arcos diafragma a la mitad, abrir las ventanas y mantener la altura de los muros de la nave central. Sin embargo, la presencia de semicolumnas en el tramo occidental del muro sur, de las cuales se conserva su mitad inferior, y la originalidad del tramo correspondiente del muro norte eliminan la posibilidad de que se contemplasen tres ventanas por muro, por lo que las ventanas orientales conservadas son las únicas proyectadas y realizadas.

Ante la unidad de los paramentos, los arcos diafragma, sus soportes y las bóvedas de los dos tramos orientales en ambas naves laterales, esta anómala disposición de columnas y ventanas solamente se puede explicar mediante una corrección en marcha. Ante la imposibilidad de reconstruir tanto bóvedas de cañón como de aristas por la posición de la ventana, la tercera opción posible hace pensar en una cubierta de madera que podría haberse servido de los arcos diafragma en los cuatro tramos occidentales, como marca la presencia de las semicolumnas del muro sur y los pilares cruciformes, y prescindir de ellos en los dos tramos orientales, donde se abrían las ventanas. La decisión de sustituir la armadura de madera por bóvedas de aristas, menos problemáticas que las de formato de cañón por lo indicado, implicó la partición del tramo oriental rectangular en dos cuadrangulares mediante la introducción de arcos transversales, cuyas columnas se adosan al muro, pero que se solidarizan con el tapiado de la ventana y sirven

\footnotetext{
32 Planteada por Gudiol y Gaya (1948: p. 190).
}

a las bóvedas de $\operatorname{aristas}^{33}$, cuya geometría salva sin problemas las alturas de las claves de las arquerías.

Por lo tanto, una vez completados los muros [A 169], tendría lugar el abovedamiento de las naves laterales [A 103], la construcción de los muros de la nave central y su bóveda. De esta nada podemos decir, pues no conservamos ningún tramo original, aunque debemos suponer que se alzó también en sillería como el resto de las bóvedas de este Periodo II.

Como ya se ha indicado, las pinturas que decoran las bóvedas del panteón [UE 1325, A 200] cubren la puerta abierta en el Periodo IIa [UE 1225] (Figs. 8 y 26). No tiene relaciones con otras partes del edificio, por lo que ignoramos si fueron previas o posteriores tanto a su ruina (IIb) como a su reforma (IIc). De este modo, su situación en esta fase se rige por el término post quem, siendo su iconografía el principal indicio datador, el cual se mueve en un amplio periodo desde finales del siglo XI hasta mediados del XII (Fig. 1).

\section{Consideraciones generales sobre el Periodo IIa}

El análisis de la fábrica adscrita a este periodo ofrece datos que pueden ayudar a avanzar en distintos temas tratados por la investigación dedicada a San Isidoro, por lo que consideramos oportuno su sistematización de cara a una correcta comprensión de la secuencia de la basílica.

- Transepto y aula como espacios unitarios. Las juntas de unión y la presencia del capitel picado en el extremo oriental de la arquería sur han sido argumentos para debatir la forma original de la basílica románica, bien proyectada sin transepto y alterada por su posterior introducción (Pérez Llamazares 1927, Gaillard 1938, Williams 1984, Caldwell 1986, Martin 2006 y Boto 2007, entre otros), bien modificada durante el proceso de construcción para acoger este espacio (Gómez Moreno 1934, Yarza 1979, Poza 2003).

Las excavaciones de Torbado a inicios del siglo XX también exhumaron restos en la mitad oriental de la basílica, los cuales permitieron argumentar la existencia de una iglesia primitiva sin transepto. El hecho de que los ábsides actuales sobrepasen el ancho del aula fue indicio para que Gaillard (1938: pp. 11-12) y, recientemente, Martin (2005: p. 384) defendiesen la existencia de una cabecera anterior, en línea con el aula, desplazada por la inserción de un transepto y sustituida por la actual.

\footnotetext{
Gómez Moreno (1925: p. 183) califica estas bóvedas como capialzadas, pues pierden las aristas hacia la clave, ayudándose para ello del empleo de piedra toba en la zona media.
} 
Ambos autores remiten a los trabajos de Torbado, los cuales documentaron supuestamente los cimientos de los ábsides y la base de la arquería sur $^{34}$. Pérez Llamazares (1927: pp. 361-362) dice haber visto los cimientos de los primitivos ábsides semicirculares y los de los pilares eliminados por la inserción del transepto a cargo de la infanta Urraca (1072-1101). La presencia de un capitel picado en la zona inferior de la cara este del último pilar oriental de la arquería sur (Fig. 35), descubierto por DíazJiménez (1917: pp. 84-85), es argumento añadido para que Muir Whitehill (1939: p. 153) suponga la concepción de una nave central más baja sin muro alto con ventanas, proyecto que no llegaría a ejecutarse. El mismo capitel es motivo para que Martin (2003: pp. 194-198 y 2005: pp. 384-385), como ya había insinuado Gómez Moreno (1925: p. 187) ${ }^{35}$, suponga la continuación de esta arquería sur hacia el este, lo que sumado a los cimientos de la arquería y del muro sur hallados en el subsuelo y la reutilización de los elementos decorativos de los primitivos ábsides en los actuales, confirmaría la introducción del transepto y la cabecera a principios del siglo XII, bajo el patrocinio de la reina Urraca (1109-1126) ${ }^{36}$.

Williams (1973: p. 184 y 1997: p. 29) es el primero en citar los cimientos relacionados con el muro sur, los cuales asocia a una planta previa de basílica sin crucero. Opina además (Williams 1984: pp. 286-288) que la construcción del "primer transepto" saliente del aula sería el de la catedral de Santiago de Compostela, alzado hacia el año 1100. El transepto de San Isidoro sería deudor de aquel, como justificarían las marcas de cantero análogas, $\mathrm{y}$, por ello, posterior a esta fecha.

La secuencia obtenida en el análisis hace revisar esta propuesta y sus argumentos. Primero, llama la atención que ni Díaz-Jiménez (1917) ni Gómez Moreno (1925 y 1934) mencionen los hallazgos de Torbado en la mitad oriental de la iglesia, a lo que se puede dar dos posibles explicaciones. Bien las desconocían, lo que cuesta creer si visitaron el lugar y reconocieron los vestigios del lado occidental, bien no las consideraron como parte de la basílica. Gaillard (1938: p. 11) y Muir

\footnotetext{
34 Muir Whitehill (1939: p. 152, n. 2.) sigue la propuesta de Gaillard (1938) y anota que este le comunicó por escrito estos hallazgos inéditos, los cuales le habían sido facilitados a su vez por el propio Torbado.

35 "Al surgir estas pilas no se había planeado el crucero, pues llevan rastros de capiteles bajos hacia él, para continuación de naves, que luego fueron deshechos." Esta nota es en parte incorrecta, pues no se conserva a la altura correspondiente, como se ha indicado en texto, un capitel picado en la arquería norte.

36 También argumentado por Martin (2006, 2008a y 2008b) y seguido por Müller-Reissmann (2009: p. 213).
}

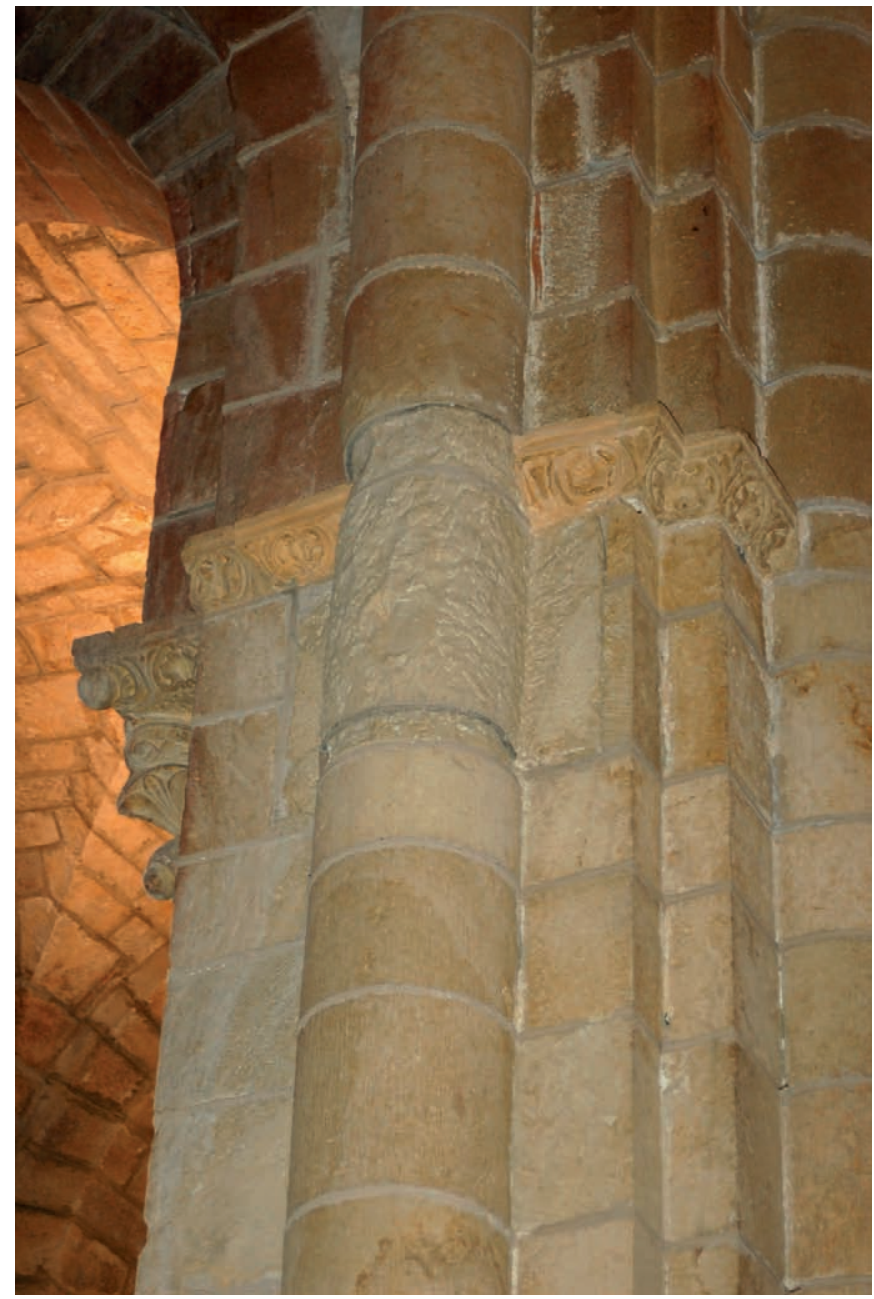

Fig. 35. Capitel sur inferior picado [UE 1272, A 175] entre molduras restauradas [UE 1271, A 178]

Whitehill (1939: p. 152) son los primeros en referirse a ellas, aunque la primera publicación de un plano al respecto se lo debemos a Williams (1984: p. 285, fig. 6, también en Martin 2005: p. 407, fig. 9 y 2006: fig. 7). En este dibujo (Fig. 36) se observa cómo un tramo de muro se alinea con el paramento meridional del aula y otro tramo, de planta angulosa, se sitúa junto al pilar más oriental de la arquería sur. La misma planta reproduce en un trabajo reciente (Williams 2011: p. 98, fig. 6), donde también publica los dibujos inéditos que documentan los vestigios considerados cimientos de la arquería sur (planta) y del aula (planta y alzado norte y fotografía del mismo lado ${ }^{37}$, Williams 2011: p. 101, figs. 11-13; nuestra Fig. 36).

\footnotetext{
37 Fotografía ya publicada por Williams (1971: p. 11), cuyo conocimiento y copia agradecemos a Th. Martin (IH-CSIC).
} 

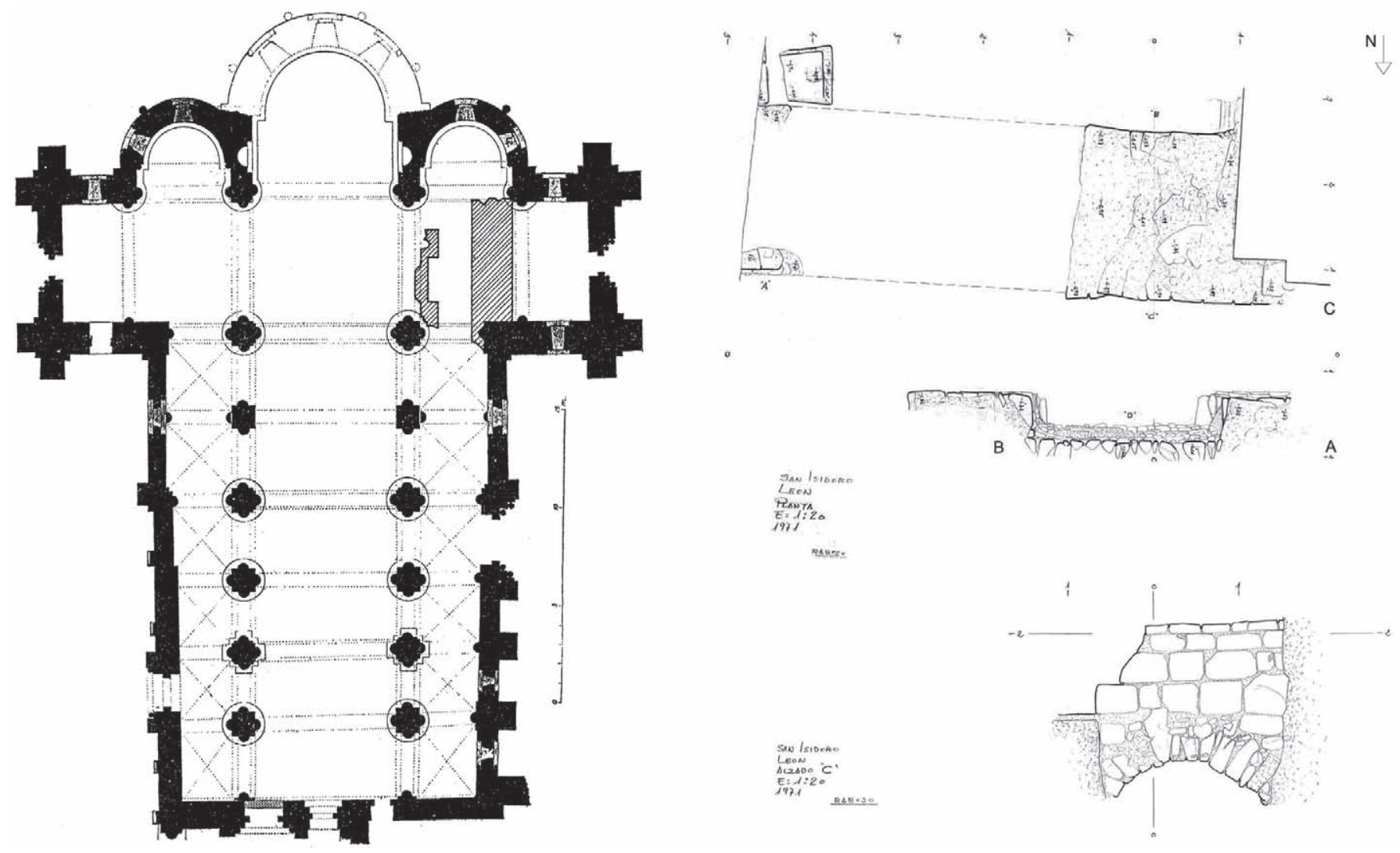

Fig. 36. Planta de Williams (1984), con trama rayada los cimientos que atribuye a la primitiva iglesia románica, y dibujos de las estructuras documentadas (Williams 2011, modificado; el alzado inferior corresponde a la cara norte de la estructura meridional dibujada en planta, marcada con una "C")

Aun partiendo de la base de que ignoramos el tipo de cimentación del resto de las arquerías, llama la atención que el muro que se supone como su cimiento no esté alineado con la arquería meridional, situándose en realidad al sur de ella, y que, además, ocupe el sitio del supuesto intercolumnio. Esta arquería, según Martin (2003: pp. 194-198 y 2005: pp. 384-385), se asentaría en el capitel picado (Fig. 35), el cual, sin embargo, no tiene su pareja en la arquería norte (Fig. 37), como ya indicase Díaz-Jiménez (1917: p. 85). Por lo tanto, los indicios de una arquería que continuaba hacia el este son inciertos en el lado sur e inexistentes en el norte.

Respecto a los cimientos del muro sur del aula, aunque la planta idealizada representa un muro que recorre todo el ancho del brazo sur del transepto, los vestigios parecen ser menores (como demuestra la planta incompleta), llamando la atención que el muro se asiente sobre una bóveda, elemento que desde luego supone una debilidad para la cimentación de un edificio de las dimensiones de San Isidoro. Tanto como si muro y bóveda inferior son unitarios, como si son sucesivos, creemos arriesgada la presencia de una bóveda como parte de un cimiento. Como ya afirmó Viñayo (1964: p. 106) de forma genérica y como supusieron los arqueólogos del Instituto Arqueológico Alemán de Madrid (según recoge Williams 2011: p. 97), creemos que estas estructuras pueden ser previas, tal vez de época romana.

Tampoco hay motivos para pensar que los elementos decorativos de los ábsides laterales procedan de los primitivos. No presentan huellas de retalle ni de adaptación, por lo que fueron realizados para estos ábsides. Finalmente, como ya hemos explicado, las juntas de obra reflejan el avance en la construcción del edificio, pero no etapas históricas de calado, identificadas no solo en el transepto, sino también en otros tramos del edificio (Fig. 19).

Cierto es que el picado del capitel meridional [UE 1272, A 175], del cual se observan restos del follaje inferior, no está correspondido por uno septentrional (Figs. 35 y 37). A esa altura, lo que se aprecia es un reajuste 


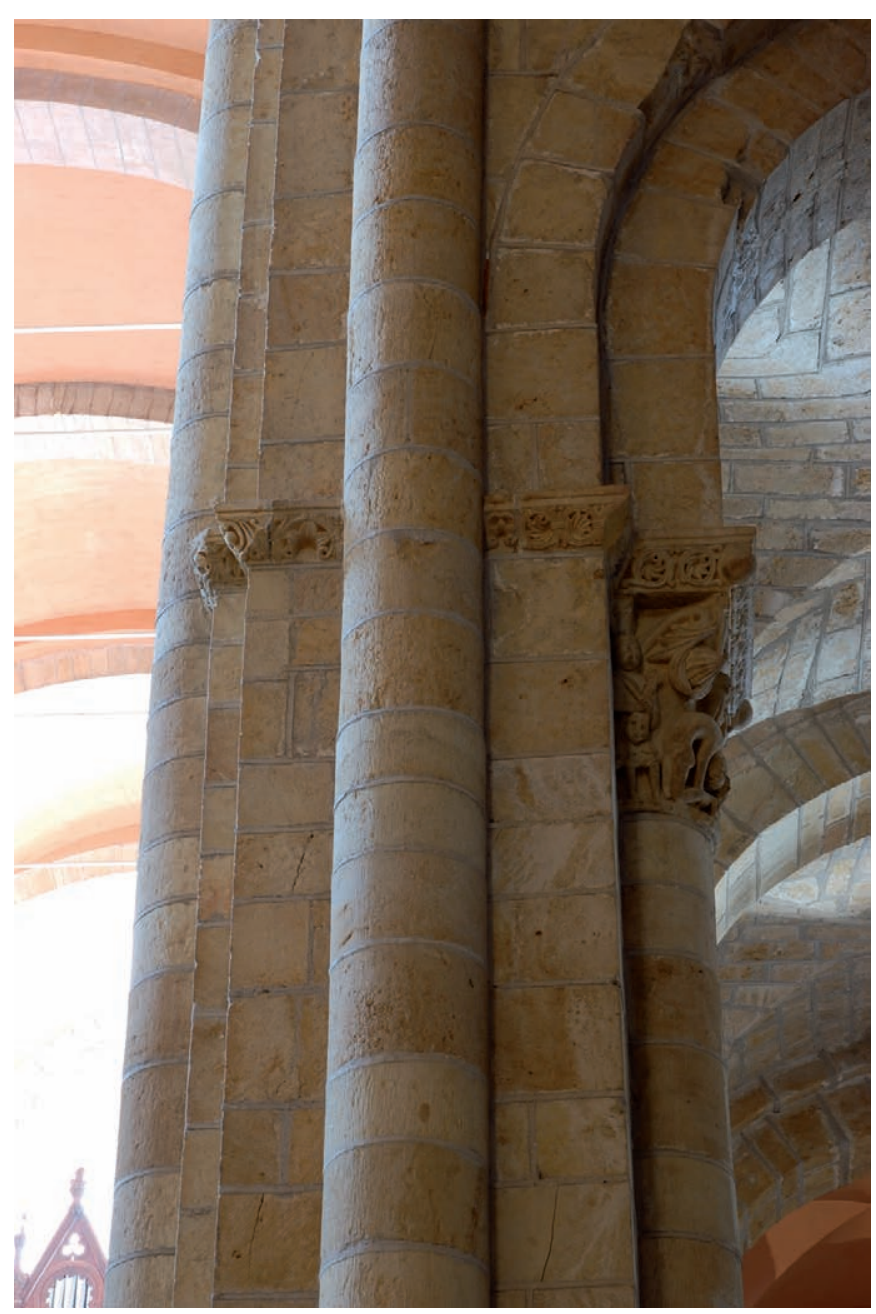

Fig. 37. Punto donde debería ubicarse el capitel norte [UE 1077, A 102] si la arquería continuase hacia el este

en la sillería en el correspondiente norte, con varias juntas verticales coincidentes, que vendría a confirmar el cambio de proyecto dentro de este periodo, pero no la proyección de una arquería hacia el este desmontada posteriormente.

- Transformación del proyecto original. El proyecto de la iglesia románica de San Isidoro adopta un esquema sencillo de aula de tres naves, transepto y triple cabecera absidiada, todo ello abovedado. El reto de la obra consiste en la adaptación a un conjunto preexistente (Periodo I), lo que supone un ajuste tanto de la planta como de los alzados.

Parece que la iglesia avanzó desde el Occidente, aprovechando las líneas marcadas por el edificio preexistente (Periodo I). El muro sur, por simetría con el norte de la fase previa, sería posiblemente ciego, pues la ubicación original del vano de acceso meridional indica que no se contemplaba una pareja de ventanas para este muro. Por lo tanto, como confirman además los pilares cruciformes emparejados con los pilares solidarios con el muro meridional, las naves laterales tendrían cuatro tramos occidentales desde su inicio. Adicionalmente se puede decir que la hipotética presencia de tres ventanas similares a las dos actuales en el muro sur, realizadas en el Periodo IIc, rompería toda la simetría del edificio.

La obra discurre hacia el este. Una trama de andamios permite construir en "extensión" una planta de aula de tres naves y transepto concebida como tal desde su inicio. La continuidad de los muros meridional y septentrional con los correspondientes occidentales de los brazos del transepto, realizados por un mismo grupo de canteros, como demuestra la coincidencia del tipo de mechinales y de las marcas entre los paramentos por debajo de la imposta inferior y los situados entre las impostas bajas y medias, con sus oportunas juntas de encuentro, avalan la presencia de un proyecto unitario. Transepto y cabecera muestran además su coincidencia en el tipo de ventanas, todas ellas formalmente idénticas, y en su fábrica continua.

Es la decisión de abovedar el edificio lo que implica un ajuste en los únicos tramos en los que se habían dispuesto ventanas, los orientales del aula. Ni el muro ni el correspondiente pilar enfrentado de las arquerías habían sido proyectados para sujetar un arco fajón ni en la nave central ni en las laterales. En la nave mayor, la ausencia de las pertinentes columnas se soluciona mediante la introducción de una ménsula para sostener el fajón de la bóveda, recurso que no puede emplearse, sin embargo, en la nave lateral por la presencia de la ventana. Únicamente la introducción de una pareja de columnas permite cubrir el espacio, ahora dividido en dos tramos. En cualquier caso, es significativo cómo la propia arquería ya suponía un obstáculo a la ventana, cuya apertura parece forzada por la necesidad de aportar luz a las naves laterales, pero cuya disposición fue errónea.

Este procedimiento de oeste a este parece refrendarse precisamente con la junta vertical, la denominada "cremallera" que se observa en la nave norte y que marca el paso a esta nueva fase que contempla la finalización del muro norte, realizado con otro andamio y reforzado con arcos ciegos que permiten equiparar los grosores de los muros de los distintos periodos (I y IIa), y el abovedamiento del edificio. En este momento se acaba de desmontar el muro de la primera basílica (Periodo I), la cual no podía estar en uso pues sus arquerías y restantes muros perimetrales habían sido eliminados durante la 
construcción de la nueva basílica. Puede que el tramo ocupado por esta obra [UE 1075] funcionase como una puerta de obra, cerrada una vez se termina el perímetro del edificio. Debemos aclarar aquí que la última Etapa 3 corresponde al abovedamiento de las naves laterales y de la central, la cual no conservamos. Las bóvedas del transepto y sus arcos fajones polilobulados pueden adscribirse tanto a la Etapa 2, donde están incluidos, ya que al ser independientes estructuralmente no necesitan del aula para su erección, como a la Etapa 3, si consideramos que esta lo es únicamente de abovedamientos.

- La basílica no está sola: estructuras occidentales. Aunque el análisis se circunscribe a la basílica, no podemos obviar la pertenencia de los vanos occidentales (Figs. 8 y 25 ) a este periodo y su valor como indicadores de la presencia de unos espacios coetáneos a ella en esta zona. La disposición de los arcos lobulados en la cara este y de las jambas en la oeste del vano que comunica con el panteón indica su concepción como puerta interior, de paso desde un espacio construido a la propia basílica, y no abierto, como manifestaría la posición inversa de esos elementos. Por el contrario, el tapiado del arco superior supone la pérdida de relación directa entre la iglesia y la denominada Cámara de Doña Sancha, aunque eso no impide que siga existiendo una estructura elevada, a modo de coro, que sirva al nuevo vano sur alto.

Idénticos caracteres encontramos en los vanos de la nave meridional de este mismo sector. Situados en eje vertical, la apertura hacia Occidente de sus hojas, como anotó Gómez Moreno (1925: p. 190), y la disposición de las columnas en el superior y del tímpano en el inferior en la cara oriental subrayan el mismo hecho: la presencia de un cuerpo construido de dos alturas en el ángulo suroccidental del edificio ${ }^{38}$. A este respecto, las fuentes documentales mencionan la existencia de un palatium regis en el año 1096 (Estepa 1977: p. 125), aunque parece que existía ya en tiempos de Fernando I (1037-1065). Williams (1997: pp. 13-14) lo atribuye al rey Alfonso V (999-1027), el cual habría trasladado el palacio del siglo X situado en la zona sur a esta nueva zona norte de la ciudad, como parte integral de la iglesia entonces dedicada a San Juan.

Risco (1786: p. 205) parafrasea a Lucas de Tuy (m. 1249), canónigo de San Isidoro (1221-1239), quien se refiere a "como la Reyna Doña Sancha, hermana del dicho Emperador D. Alonso [Alfonso VII, 1126-57], morase en

\footnotetext{
38 No hallamos indicios de una tribuna de madera asociada al vano superior como la propuesta por Fernández González (2009: p. 52).
}

el palacio Real, que era pegado con la Iglesia de S. Isidro, è continuamente se ponia à orar en una ventana que está en lo mas alto de la pared de la nave mayor de dicha iglesia”. Este pasaje indica la existencia de un espacio edificado adicional desde el que acceder a la cámara alta. Dado que al norte no hay un acceso desde esta, lo propio es pensar que se situase en el flanco sur. De ser así, este espacio, el probable palacio, podría ser el aquí documentado. Gómez Moreno (1925: p. 190), también según Lucas de Tuy, considera que el vano inferior, cuyo tímpano con crismón atribuye a la renovación de las estancias previas en el siglo XVI, daba acceso al palacio de Doña Sancha, hermana de Alfonso VII, y que el superior servía de ventana para asistir a la oración. Martin (2005: p. 382), por el contrario, identifica el palacio con la tribuna y el panteón, construido en torno a 1080 por la infanta Urraca, formando parte del primer envite de la iglesia románica.

Este supuesto palacio pudo verse afectado por la ruina de la obra (Periodo IIb), aunque el enfoscado del muro perpendicular al ángulo suroeste de la basílica impide aportar argumentos estratigráficos. El siguiente elemento en la secuencia es la biblioteca (Periodo IIIc), por lo que queda una extensa laguna a resolver entre el palacio del siglo XI y la biblioteca del siglo XVI. A este respecto, Quadrado y Parcerisa (1855: p. 339) mencionan que "Hacia el norte de la ciudad, en una vasta y herbosa plaza ocupada ahora por solitaria fuente, y solar un tiempo del primitivo palacio real reedificado en cal y piedra por la varonil madre de $\mathrm{S}$. Fernando, que el rey Católico dejó desaparecer para dar mas desahogada vista al monasterio".

\section{Interpretación y cronología}

Este periodo supone el diseño, construcción y primeros usos de la basílica románica, lo que implica el desmonte progresivo del edificio primitivo sobre el que se asienta (Fig. 3). El análisis evidencia que la construcción es el fruto de un único proyecto constructivo que se organiza mediante la participación de distintas cuadrillas de canteros y constructores trabajando al mismo tiempo, sobre el mismo andamio, que al encontrarse dan lugar a las juntas de obra observables en el muro. Los encuentros verticales suelen ser escalonados, mientras que los horizontales suelen aprovechar las impostas.

$\mathrm{Y}$ es ahora cuando entran en juego las fuentes documentales y epigráficas, en las que gozan de un protagonismo destacado la infanta Urraca y el monarca Alfonso VII. Respecto a la primera, el término amplificavit empleado en su inscripción sepulcral (m. 1101), referido ya en la introducción, podría interpretarse como el comienzo de 
esta grandiosa obra que conserva parte y destruye otra de la obra primitiva. Como ya hemos indicado, esta opción responde al pragmatismo constructivo y evidencia, en nuestra opinión y de manera indirecta, la presencia del panteón. Tanto Alfonso VI (1065-1109) como la reina Urraca (1109-1126) pasan algo desapercibidos en la historiografía, la cual vuelve a centrar su atención en Alfonso VII (1126-1157) gracias a la inscripción que recoge la consagración del edificio en el año 1149.

Sin embargo, antes de llegar a esta fecha de mediados del siglo XII se deben tener en cuenta varios datos. Desde el año 1063 hasta el 1149 pudieron ocurrir muchas cosas. En primer lugar, debe considerarse el epitafio tallado en el muro sur de la iglesia, atribuido por Gómez Moreno (1925: p. 212) al obispo D. Pedro, fallecido en 1112 (traducción V. Infra; Fig. 38). Esta fecha debe tomarse con cuidado al tratarse del traslado del cuerpo, siendo tallada en un momento posterior en el sillar in situ de la fábrica. Solo nos vale para decir que este muro ya estaba construido entonces, en un momento posterior al año 1112.

En segundo lugar, la fecha del 1124 (Era 1162) presente en un sillar del paramento exterior del ábside norte (Fig. 39), data que pertenecería al gobierno de la reina Urraca (1109-1126), podría servir para precisar la extensión de la construcción en este momento. Gómez Moreno (1925: p. 212) se fija en ella, pero desestima su valor cronológico al considerarla como parte de un posible epitafio. Pérez Llamazares (1927: p. 362) actúa de manera similar para defender así su propuesta de que la infanta Urraca (10721101) fue la artífice de la cabecera y transepto actual, indicando que en la fecha de 1124 la obra, dada su magnitud, estaba aún en marcha. Gaillard (1938: p. 13) también opina que se trata de un epitafio, pero reutilizado, por lo que da relevancia a la fecha. Aceptada como tal también por Williams (1973: p. 183), Martin (2005: pp. 386-388 y 2006: pp. 111-126) considera que esta inscripción fue movida desde el lado occidental de la iglesia, pues sus dimensiones coinciden, en su opinión, con un agujero en la parte alta del palacio y fue rodeada en negro por Torbado, lo que indica que él pensaba que no era original; además tenía otra línea perdida, de la que queda una $\mathrm{F}$, posible inicio de FECIT o FACTA. Esta fecha conmemoraría la finalización de la obra y coincidiría con la cronología tradicionalmente atribuida a la escultura de la cabecera en torno al año $1125^{39}$. Ignoramos los motivos por los que Torbado marcó este sillar, tal vez por tratarse de una pieza significativa al tener una fecha, pero no parece que esta pieza esté movida, co-

\footnotetext{
${ }^{39}$ Para Durliat (1990: p. 366), ca. 1110, coetánea a la Portada del Cordero.
}

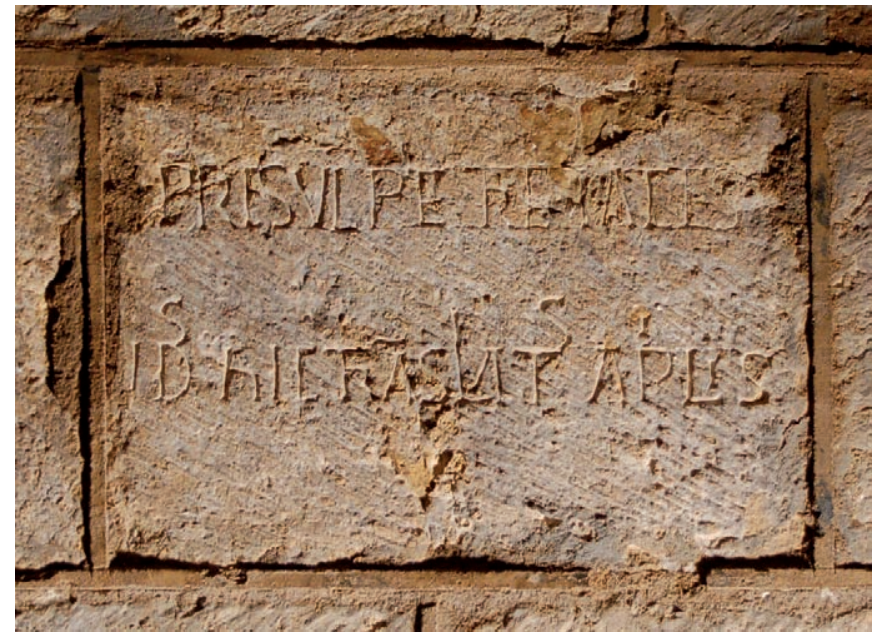

Fig. 38. Epitafio tallado en el muro sur del aula [UE 1361, A 208]

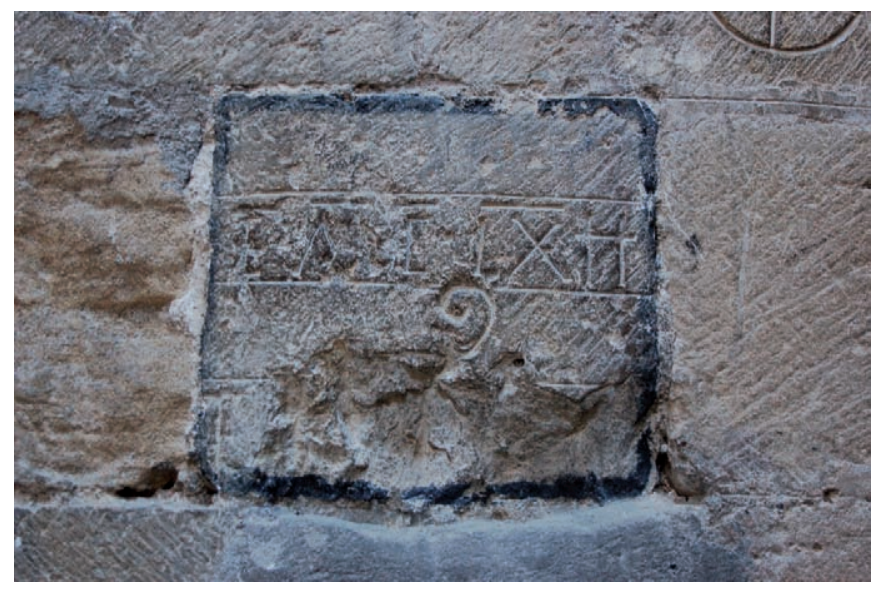

Fig. 39. Epígrafe con la fecha Era 1162 (Año 1124) [UE 1078, A 102] en el exterior del ábside norte

incidiendo bien su altura con la hilada en la que se inserta (Fig. 39). Tampoco parece el sitio apropiado para situar un epígrafe de fundación, al exterior de un ábside menor, cuyo contenido, por otro lado, sería bastante pobre como reflejo de la obra de una reina. El hecho añadido de que se omita el nombre del patrocinador, sea la reina Urraca o no, es un serio indicio de que nos encontramos ante un epígrafe de otro carácter, tal vez funerario como han indicado ya otros autores.

En tercer lugar, la interpretación del término superaedificavit en la lápida de Pedro de Deustamben abre una serie de posibilidades que debemos remitir, por el momento, a la interpretación del Periodo IIc y que adelantamos únicamente en tono de pregunta: ¿Qué obra consagró Alfonso VII en 1149, la basílica románica (Periodo IIa) o la basílica románica restaurada después de un proceso de ruina y posterior restauración (Periodo IIc)? 


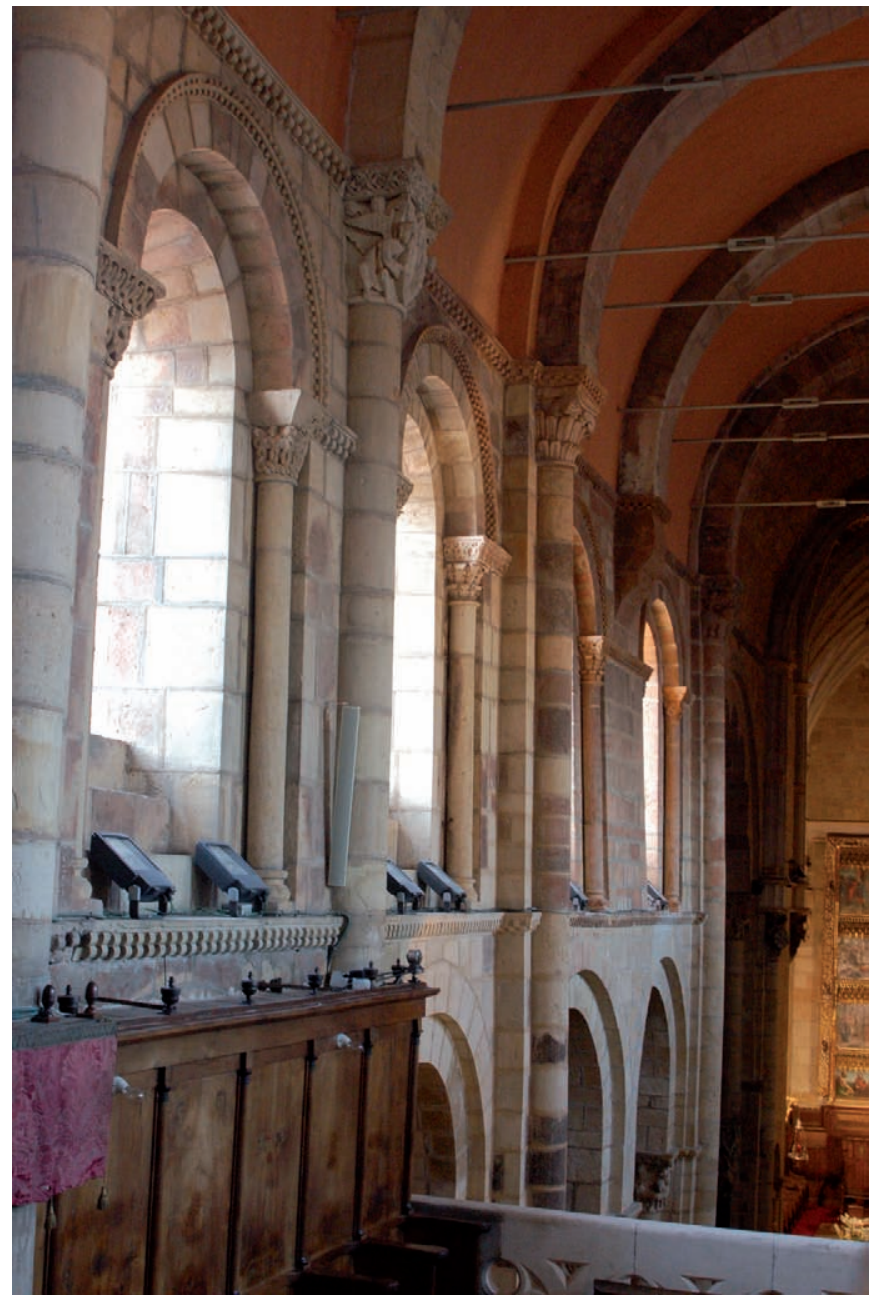

Fig. 40. Deformación [A 104] del muro norte de la nave mayor, con la segunda columna desde el este restaurada [UE 1150, A 109] y bóveda y arcos fajones en ladrillo [A 109] reparados

\section{Periodo IIb. Ruina inmediata}

[A 104. UE 1055, 1157, 1267, 1338]

\section{Análisis arqueológico}

Probablemente la desproporcionada diferencia de altura y luz entre la nave central y las laterales fue el origen de un movimiento en el sector occidental del edificio que le costó sus cubiertas y gran parte de los muros del aula. El replanteo del diseño original para introducir las cubiertas abovedadas puso en evidencia que esa diferencia era excesiva. Los empujes de las bóvedas de cañón de la nave central serían parcialmente acogidos por la parte alta de los muros laterales, pero la pronunciada altura de estos, cuyo único refuerzo son los contrafuertes, provoca que los empujes caigan en parte fuera del espesor de los muros. De este modo, el edificio se abrió en su mitad oeste, donde están los

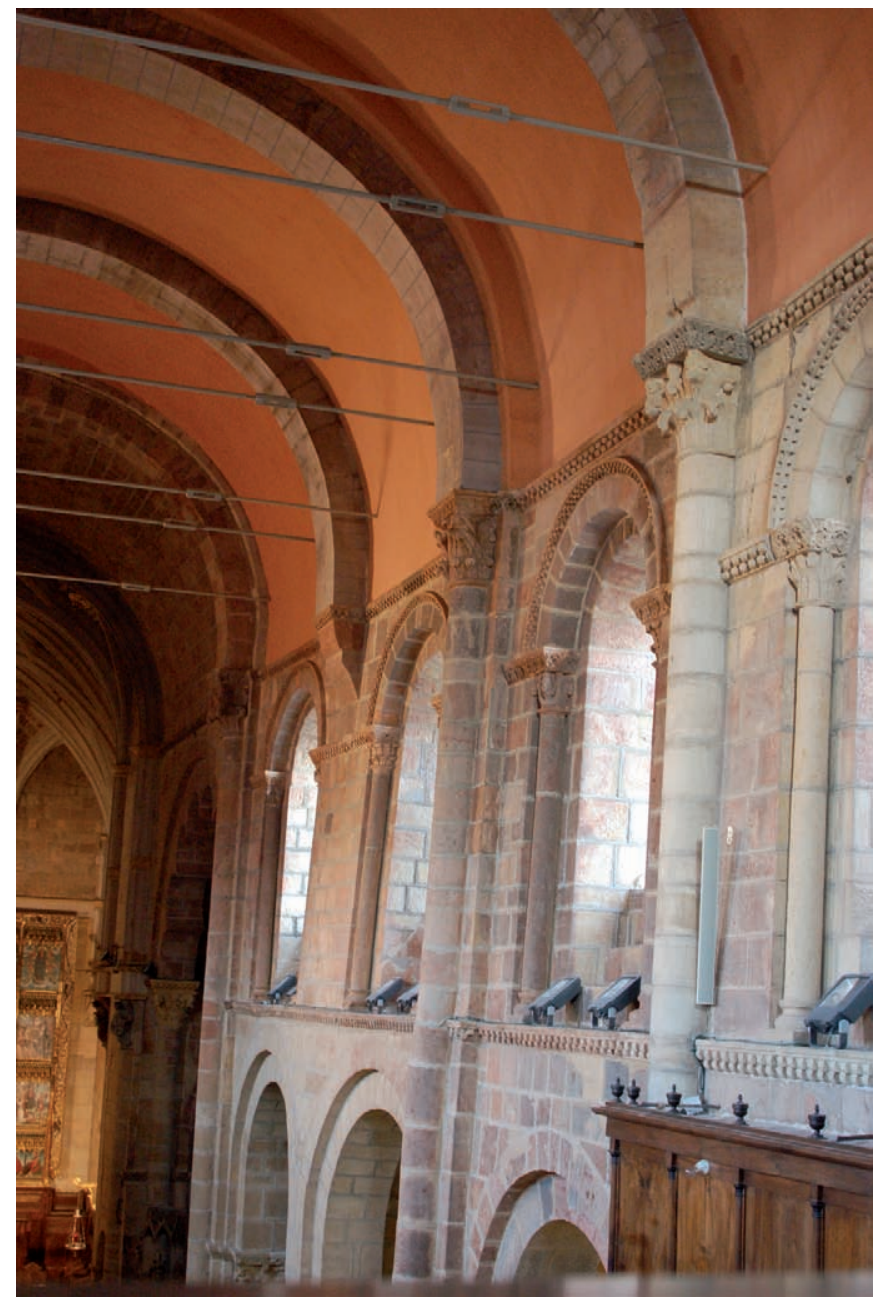

Fig. 41. Deformación [A 104] y corrección (columna central de la imagen) del muro sur de la nave mayor y bóveda y arcos fajones en ladrillo [A 109] reparados

quiebros de los soportes individuales (semicolumnas) y continuos (arcos, muros), los cambios acusados de los planos y las bóvedas de ladrillo. En el sector oriental, la bóveda del crucero, independiente de la nave central gracias al arco de embocadura, mejor contrarrestada por cañones perpendiculares y más altos que las cubiertas de las naves laterales, aguantó y, con ella, todo el transepto y la cabecera.

La ruina [A 104], profundamente reparada tanto en el Periodo IIc como en el VIa, aún se observa en el pandeo de los muros de la nave central, los cuales se inclinan hacia el exterior del edificio por encima de sus arcos (Figs. 40 y 41). Afortunadamente para nosotros, las reparaciones en los muros altos fosilizaron los movimientos, convirtiéndolos en ruinas estabilizadas. Estas son especialmente notables en la arquería meridional. En su tercer pilar desde el este (Fig. 41), 
la semicolumna [UE 1338] se dobla hacia el exterior, siguiendo la deformación del muro. Desde este punto a occidente, la nave central se perdió, estando su parte alta ya enderezada en las restauraciones del siglo XIX, aunque sobre las tres ventanas más orientales de la fachada sur de la nave central [UE 1055] se produce un escalón que debe atribuirse al mismo hecho. El mismo efecto sufrió la arquería norte (Fig. 32), donde el movimiento provocó escalones o cambios de planos en el hombro occidental del arco más oriental [UE 1157]. Este salto se prolonga hasta la línea de imposta bajo las ventanas altas.

En el brazo norte del transepto, una grieta [UE 1267] recorre la bóveda transversalmente. El hecho de que esta zona resistiese a la ruina apunta la posibilidad de que esta grieta pertenezca a este movimiento, aunque tampoco podemos descartar su origen por asientos diferenciales.

\section{Interpretación y cronología}

La finalización del edificio, con la puesta en carga de la bóveda o secciones de bóvedas de la nave mayor se manifestó como una prueba estructural no superada. Las dimensiones de la nave central con una luz de 7,5 $\mathrm{m}$ y una altura de 17 $\mathrm{m}$ (a la clave de la bóveda) doblan las correspondientes de las naves laterales (norte A 2,7 m, H 8,5 m; sur A 3,2 m, H $8,5 \mathrm{~m})$. Esta notable diferencia impidió que los muros de la nave central (A 1,10 m) funcionasen como un efectivo contrarresto de la bóveda de cañón. La nave central cedió, como demuestran los soportes vencidos hacia el exterior, por su lado occidental y, con ella, las naves laterales, mucho más bajas de lo debido para poder funcionar como contrarrestos de la central. El muro macizo de la nave norte (Periodo I) (Fig. 4), donde el claustro ejercería la función de gran contrafuerte, respondió de manera efectiva. Aquí el movimiento se observa en los saltos en las hiladas de las dovelas de los arcos transversales, conservadas hasta una altura de tres-cuatro sillares en los arranques meridionales (Fig. 42), y en el retalle de algunas de las marcas de cantero de las piezas reutilizadas. Las marcas también cambian de formato, evidenciando todo ello la obra de reparación (Periodo IIc). No sucedió lo mismo con la fachada meridional que, exenta de refuerzos, se arruinó prácticamente hasta la línea baja de imposta.

El temor a la ruina total se evidencia en la labor de andamiaje del edificio [UE 1001, A 126] (Fig. 27), la cual reforzará en el Periodo IIc aquellos tramos que resistieron, el transepto y la cabecera. Las bóvedas transversales de los brazos (4 $\mathrm{m}$ más bajas que las centrales) y la del crucero, con la misma luz, altura y dirección que

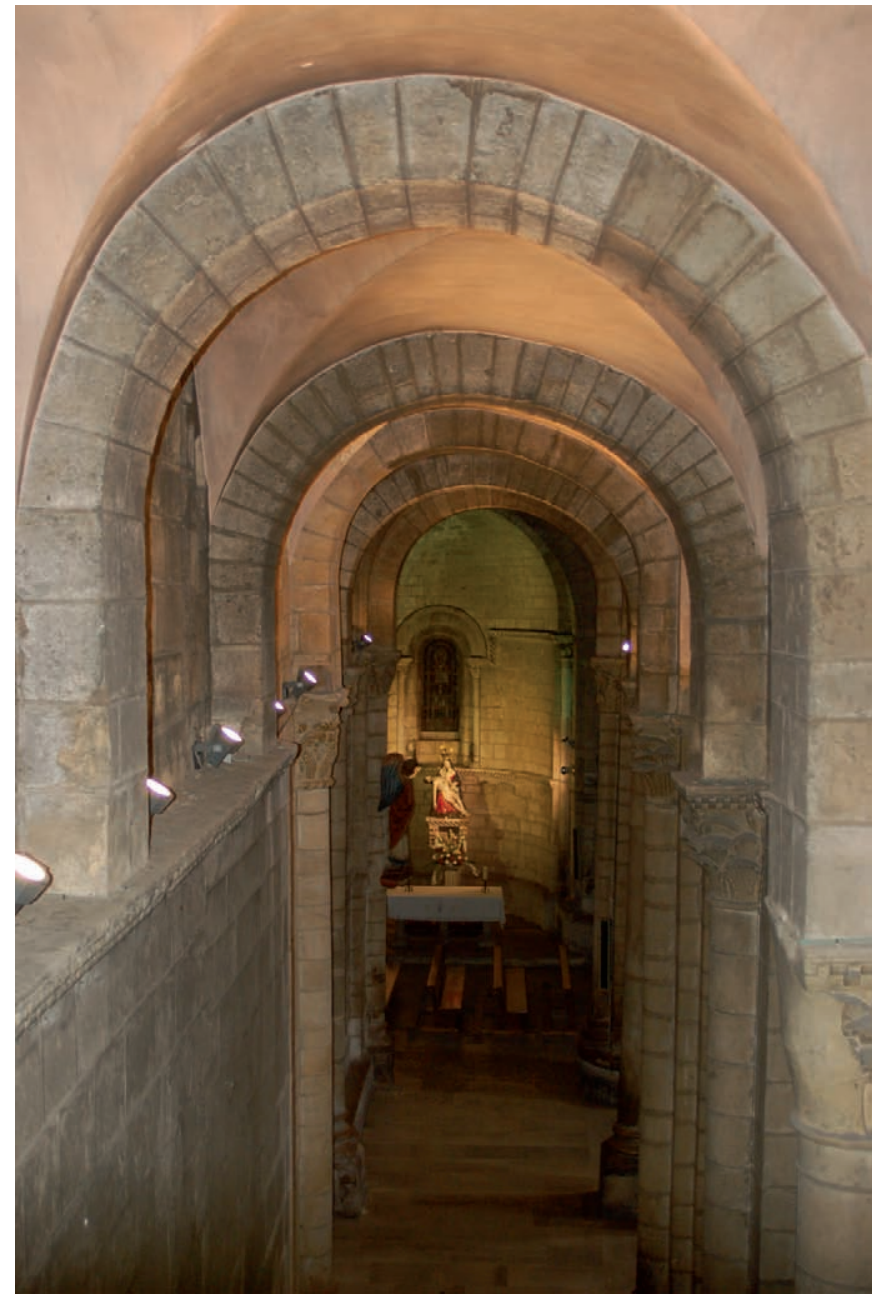

Fig. 42. Arcos de la nave septentrional en los que se aprecia su deformación, mostrando arranques rectos y tercios superiores reconstruidos [UE 1082, A 106]

las de la nave central, no se vieron sujetas a los desplazamientos del aula, actuando además como freno de los efectos de la ruina hacia el este. La disposición adicional de arcos fajones y transversales convirtió a la estructura en un conjunto fragmentable que respondió de forma individual al proceso de descomposición.

\section{Periodo IIc. Reparación}

[A 106. UE 1034, 1082, 1083, 1239, 1292, 1354; A 107. EU 1038, 1241; A 109. EU $1054,1056,1057,1058,1059,1150,1152$, $1336,1365,1368,1369,1370,1375$; A

126. EU 1001; A 208. EU 1361]

\section{Análisis arqueológico}

La reparación de los estragos producidos por la ruina del Periodo IIb debió tener lugar rápidamente a juzgar por la 


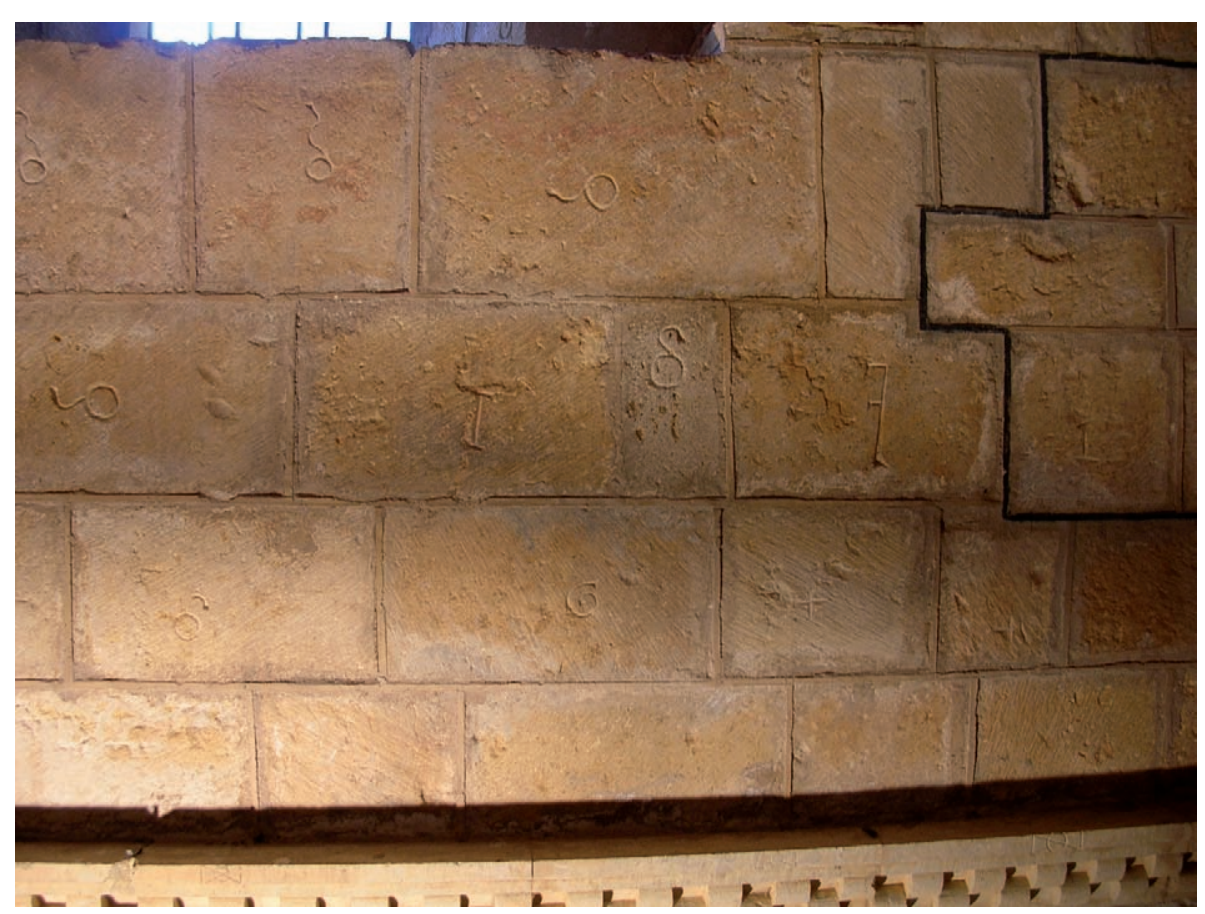

Fig. 43. Detalle de la fábrica del Periodo IIc en el ángulo occidental del muro sur [UE 1034, A 106], entre el alfeizar de la ventana y la imposta baja, con abundantes marcas de cantero secuencia estratigráfica, la técnica constructiva y el estilo decorativo, el cual sigue un lenguaje aún románico. Los caracteres de esta obra continúan las pautas del Periodo IIa, indicios evidentes de que no debió transcurrir un largo periodo de tiempo entre la ruina (Periodo IIb) y la restauración (Periodo IIc). Su fábrica (Fig. 43) se caracteriza y distingue por los siguientes elementos:

Las hiladas son horizontales, pero se observan sinuosidades, así como algunos codos en las mismas, características que no encontrábamos en los periodos previos.

Se observan indicios de reutilización, tales como las aristas escantilladas de la sillería caliza o la presencia de abundantes marcas de cantero, de mayor tamaño y de diseño más marcado y profundo, llegando a producirse retalles de marcas.

Aunque las impostas taqueadas siguen siendo mayoritarias, se combinan con otras decoradas con motivos vegetales tanto en las ventanas superiores de la nave central como en las inferiores del tramo oeste de la fachada sur.

Se pierde el ritmo de los mechinales del Periodo IIa. Prácticamente, a excepción de una pareja de mechinales en el tímpano más occidental de la nave meridional [UE 1034], no se localizan mechinales. Es decir, se trabajó con andamios independientes.

Los alzados de esta restauración corresponden a la portada sur [A 107] y al tramo situado al oeste de ella
[A 106] (Figs. 23 y 27). Aunque en una primera lectura (Murillo 2006) ${ }^{40}$ defendimos el alzado de un forro exterior (Fig. 27) para reparar su ruina, la lectura completa muestra que toda la fachada fue elevada de nuevo y reforzada con contrafuertes [UE 1034], cuya fábrica era solidaria con la de los muros y de los cuales únicamente conservamos su base. Este muro sur se realizó en sillería caliza de tamaño heterogéneo, con aristas escantilladas $\mathrm{y}$ anchas juntas y alternancia de talla a cincel o pico pequeño y gradina (Fig. 12). Sus dos ventanas son más estrechas que las del Periodo IIa y sus arcos ligeramente apuntados, irregularidades que se suman a la diferente localización en altura tanto de las ventanas como de las impostas ajedrezadas.

Otro elemento distintivo es el notable aumento y concentración de marcas de cantero, visibles especialmente al interior (Fig. 23). Mientras la ruina del exterior afectó a casi toda la altura del paramento, no ocurrió así en el interior, donde la hilada inmediata sobre la línea de imposta baja marca la rótula por la que el muro se rompió y venció hacia fuera. Esta solución de continuidad se escalona a medida que nos aproximamos a la portada, situándose del lado de la ruina el tímpano [A 107] de la Puerta del Cordero y la bóveda de ladrillo del

\footnotetext{
40 Murillo, J. I. 2006: Arqueología de la Arquitectura. Basílica de la Real Colegiata de San Isidoro de León. Lectura de paramentos: alzado norte de la nave norte y central y fachada sur, 2006. Madrid: informe manuscrito, Servicio de Restauración de la Junta de Castilla y León.
} 


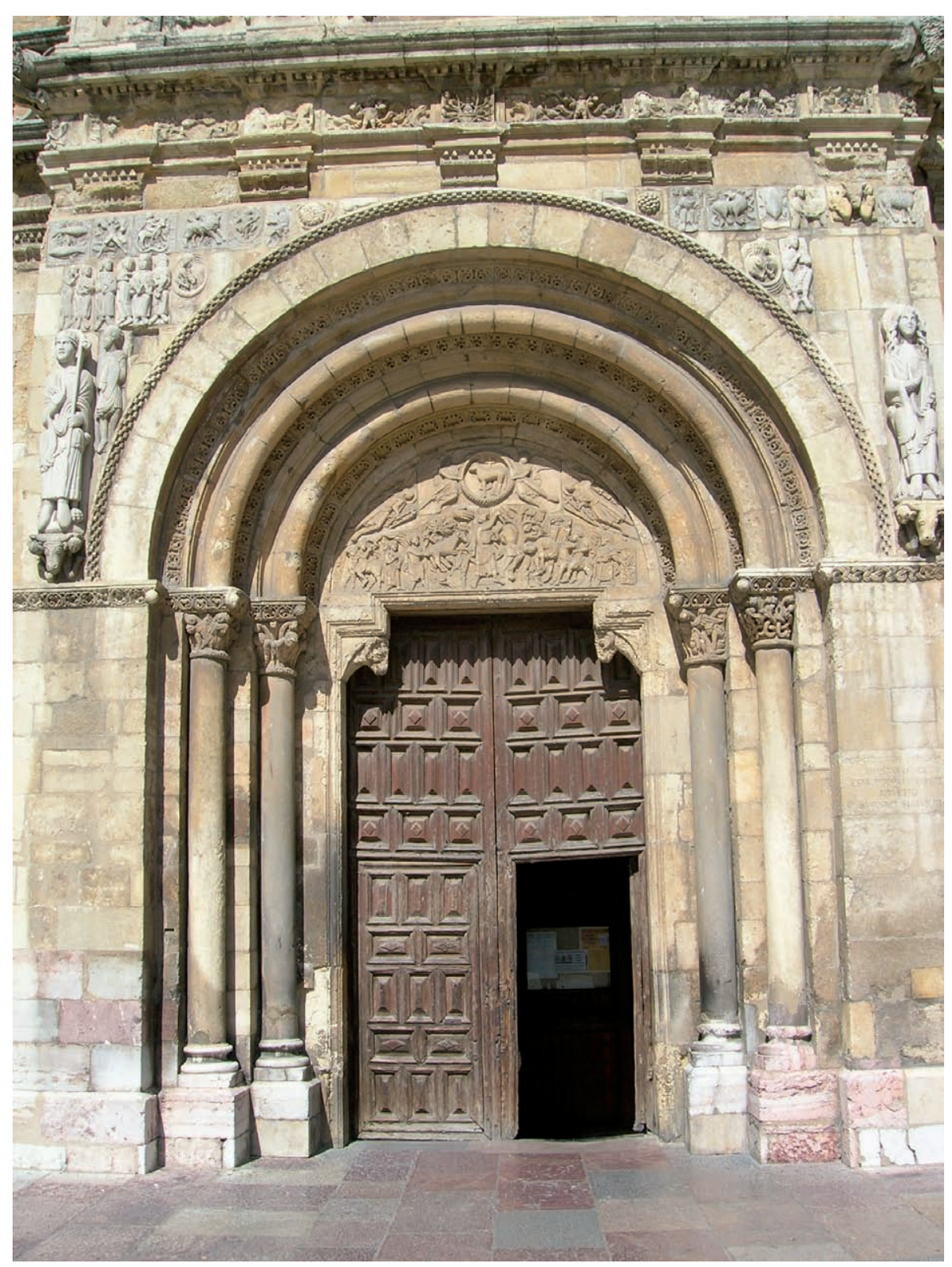

Fig. 44. Portada del Cordero, acceso principal de la nave sur [UE 1038, A 107] tramo correspondiente. En este lienzo hay unas marcas de cantero que no encontramos en el Periodo IIa: 12, 35, $41,42,45,46,48,75,84,85,87,89,91$. Son exclusivas de este momento (Fig. 24).

En su extremo occidental, la ruina del muro se detecta también en el encuentro con el muro de fachada (Fig. 5). Posiblemente la pérdida de la esquina suroeste provocó una grieta y una pérdida de material que fue rellenada con una obra [UE 1239] de sillería caliza escantillada, dispuesta en un ritmo de hiladas independiente del resto del muro occidental. Al exterior, la esquina [UE 1354] se realiza en la misma sillería caliza escantillada, pierde la línea de muro y las caras de los sillares, algunos calzados con ladrillos, se sitúan en distintos planos.

La Portada del Cordero [UE 1038, 1241, A 107] es el fruto de una reconstrucción que crea un cuerpo de tres arcos de medio punto concéntricos, el exterior apeado en machones prismáticos y los dos interiores en columnas (Figs. 27 y 44). De la primitiva portada (Periodo IIa, Etapa 1) tan solo se conservan como originales los machones detrás de las columnas de los arcos interiores, estando el occidental algo más remetido que el oriental. El empleo de material reutilizado, unos con ajustes irregulares, otros con cortes para servir de asiento a las impostas decoradas, colocadas en este Periodo IIc, con 


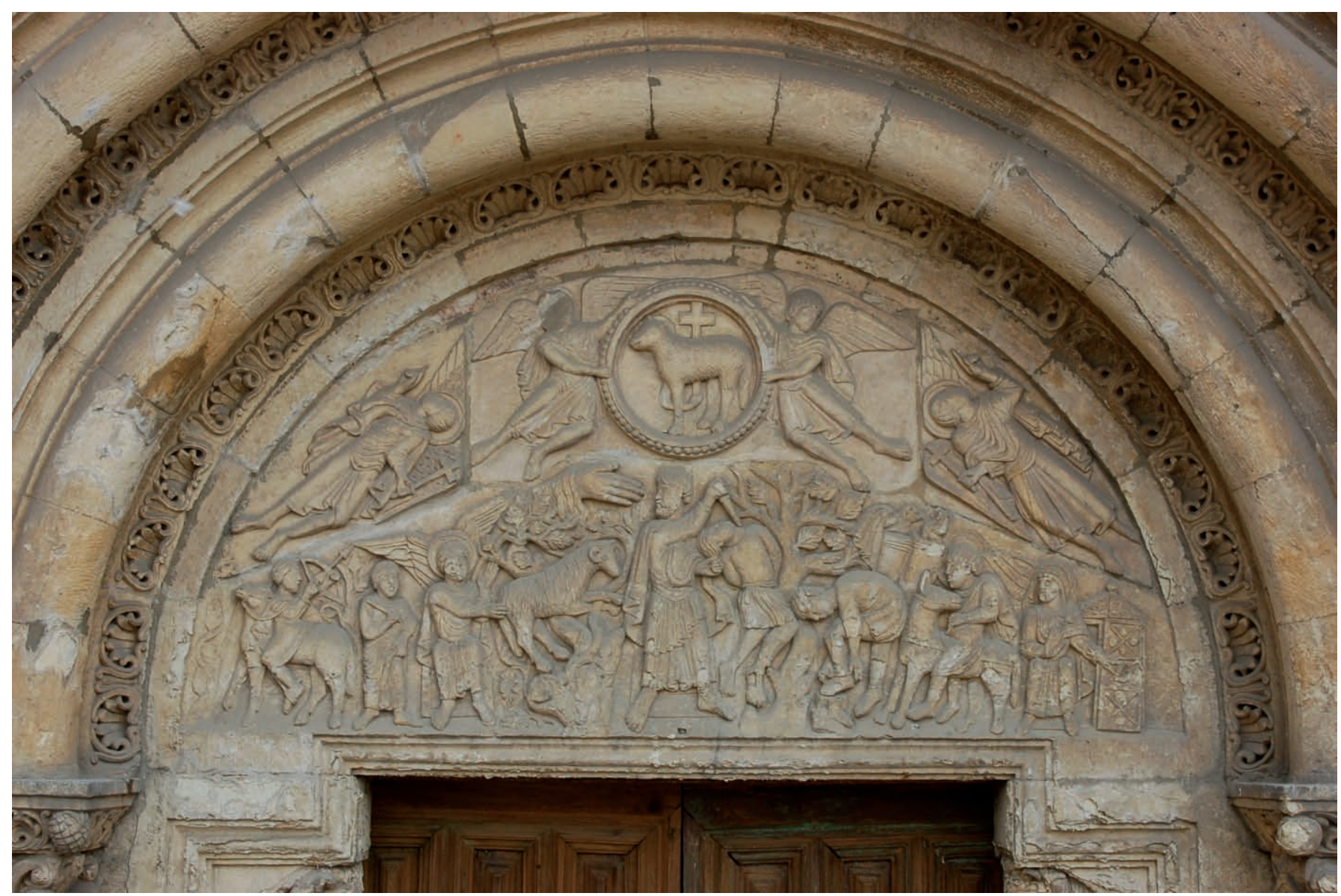

Fig. 45. Tímpano de la Puerta del Cordero [UE 1038, A 107]

el objeto de subsanar la diferencia de tamaño entre el asiento y las piezas; la destacada y novedosa presencia de huellas de gradina, como se puede observar en las jambas y el dintel de la puerta; o la solución de continuidad entre las piezas que componen las jambas y muros del Periodo IIa, evidencian la nueva obra.

A diferencia de otras piezas de la portada, la del "Sacrificio de Isaac" no está reutilizada, pues se ajusta perfectamente a su ubicación y tiene huellas de gradina original, no repasada (Fig. 45). Sin embargo, las piezas situadas por encima de ella, dos placas laterales con la representación de un ángel y una tercera central con otra pareja de ángeles soportando un cordero sagrado, no fueron concebidas originalmente para este vano. Las piezas laterales no presentan un orden lógico, dirigiendo los ángeles su mirada hacia el exterior del tímpano, fuera de la composición. El ángel occidental tiene un ala cortada $\mathrm{y}$ restos de un motivo vegetal a sus pies que evidencian que la placa continuaba. El ángel oriental tiene también un pie y parte de su aureola cortados. Todos estos ajustes son necesarios para adaptar los fragmentos a la curva del tímpano, como también delatan las juntas desiguales entre las piezas. La pieza que alberga la representación del cordero en un medallón sostenido por una pareja de ángeles presenta también huellas de gradina y una curvatura que no se ajusta a la del tímpano, delatando su uso primitivo en un tímpano de menor diámetro. Estas tres últimas piezas, es decir, las dos laterales con los ángeles y la central con el cordero, pudieron tal vez formar parte de una única placa, al modo de la central que ocupa el tímpano de la portada meridional del transepto. Los recortes han ido buscando las líneas de los perfiles de los relieves. Por lo tanto, mientras la pieza de la escena del "Sacrificio de Isaac" se introduce en este momento de reconstrucción (Periodo IIc), siendo tallada ex novo para ello, las tres piezas restantes (ángeles y cordero) se reutilizan, pudiendo ser parte de la portada primitiva en el lugar.

Algunos elementos reutilizados podrían pertenecer a la puerta original, como las esculturas de "San Isidoro" y "San Vicente", con un aspecto similar a las figuras que flanquean la puerta oriental de la fachada sur (Periodo IIa). Igualmente, llama la atención la existencia de 
lagunas sobre la arquivolta superior, la cual parece demandar una decoración más tupida (Fig. 44). Todas las piezas del zodiaco están acuñadas, presentando distintas alturas (comparar, por ejemplo, Géminis con Tauro), factura y estilo y tipo de piedra (caliza blanca frente a la habitual caliza naranja). Es más, el guerrero situado a la izquierda de la puerta tiene también su pie izquierdo cortado por el guardapolvos.

Las piezas de la portada se unifican al interior (Fig. 23) con un tímpano de ladrillo [UE 1241] dispuesto en hiladas horizontales y a sardinel que deja vista la parte posterior de la pieza del "Sacrificio de Isaac". Esta posee un grosor de $0,33 \mathrm{~m}$, correspondientes a la jamba del vano. Considerando que los ladrillos puedan alcanzar un grosor de unos $0,10 \mathrm{~m}$, las piezas de los ángeles y el cordero no deben superar los $0,23 \mathrm{~m}$, dato que confirma la heterogeneidad de las piezas que componen el tímpano al exterior. La fábrica de ladrillo no hace sino facilitar el ensamblaje de un conjunto de piezas heterogéneas.

Por lo tanto, la ruina se llevó por delante gran parte de la fachada sur, no así la norte (Fig. 4), que al ser maciza y estar reforzada por las estructuras del claustro respondió de una manera más efectiva al movimiento lateral procedente de las bóvedas. La ruina afectó a la parte alta del muro [UE 1082, 1083, 1292], cuya factura presenta las mismas características que las expuestas para la meridional. Los saltos observables a la altura de las terceras dovelas de los arranques meridionales de los arcos diafragma de las bóvedas corresponden al movimiento y relevación de los nuevos (Fig. 42), cuyas dovelas presentan marcas de cantero de mayor tamaño y reaprovechan otras anteriores, como evidencia el retalle de algunas marcas. La sillería sigue siendo caliza y tallada a hacha aplicada a $45^{\circ}$. Solo aquí volvemos a ver algunas de las marcas de cantero identificadas en el muro sur homólogo [UE 1034]: 42, 46, 82, 96.

Aquellas zonas que no cayeron, fueron apuntaladas para evitar su ruina. Así se explica la presencia de al menos seis filas de mechinales [UE 1001, A 126] que recorren los muros sur, oeste y este del transepto (Figs. 27 y 31) y de la cabecera (Periodo IIa, Figs. 27 y 33) así como el tramo del muro sur que queda al este de la Portada del Cordero (Figs. 27 y 29). Esta densa maya de agujeros cuadrados corta los muros ya construidos, coincidiendo algunas veces con las juntas. Estos mechinales son propios de apuntalamiento, como evidencia su sección triangular, no cuadrada, como sería de esperar si fuesen constructivos. No afectan a elementos de periodos posteriores ni a los restaurados en este momento
(Periodo IIc), motivo por el cual deben adscribirse a esta obra restauradora, ayudando a discriminar así las partes que no cayeron de las que fueron restauradas. Aunque hay grietas [UE 1267] en las bóvedas del transepto, el apuntalamiento evitó la ruina.

$\mathrm{Si}$ ascendemos por el edificio, observamos los mismos síntomas que en la zona inferior. Una vez reparadas y abovedadas las naves laterales, ahora en ladrillo para reducir su peso, se debió hacer lo mismo con la nave central [A 109]. Los cuatro tramos occidentales del muro sur [UE 1056, 1365] y norte [UE 1152, 1370, 1375] se rehacen y se refuerzan con contrafuertes [UE 1054, 1057, 1058, 1059] (Figs. 27 y 6). Al interior (Fig. 32), se alternan arcos fajones doblados y sencillos (Figs. 40 y 41) que marcan el ritmo de tramos abovedados también en ladrillo, siempre según las noticias de los autores (v. Infra) que las vieron.

La observación del exterior del muro norte de la nave central [UE 1370, 1375] desde una notable distancia impide ofrecer una descripción detallada de sus caracteres tipológicos, no así de su estratigrafía, la cual avala su unidad y pertenencia a este momento de la secuencia (Fig. 6). La fábrica del muro se compone de hiladas de distintas alturas, siendo más bajas aquellas que coinciden con las impostas de las ventanas. Se presentan algunos codos y saltos de hiladas. Las UE 1370 y 1375 son en realidad la misma obra, pero los refuerzos posteriores introducidos por Menéndez Pidal [A 143] en los arranques de la bóveda han provocado su dislocación partiendo el muro en dos, al quedar la parte inferior aún sometida a los empujes de la bóveda [UE 1370] y la superior [UE 1375] libre de ellos por su elevada posición y el empleo de los tirantes. Esta obra es uniforme en todo el frente hasta llegar al último contrafuerte situado entre la pareja de ventanas más orientales (Fig. 6). Mientras la parte baja del contrafuerte se encuentra, como el muro, pandeada hacia el exterior, la parte superior cae a plomo, asentando sobre la anterior gracias a un salto o solución de continuidad escalonada en ascenso hacia el siguiente contrafuerte, coincidente con los torales del crucero. Se aprecia de nuevo cómo la zona del transepto resistió a una ruina que arrastró la nave hasta este punto. El interior de la nave central [UE 1152] está notablemente restaurado [A 141], quedando su fábrica prácticamente reducida a las jambas de las ventanas (Fig. 32). Aún así, se aprecia cómo el paramento interior aguantó más, salvándose la penúltima ventana oriental, estando marcado su límite por la semicolumna [UE 1150] que recorre toda la altura de la nave central por el lado occidental de 
la segunda ventana desde Oriente (Fig. 40). Este soporte abandona la pauta de tambores enterizos combinándolos con otros fragmentados. Se adosa en la parte baja, donde ha sido reconstruido como base de la parte alta, trabada a partir de la imposta media de la nave, es decir, desde el comienzo del muro reconstruido por su lado oeste.

Del mismo modo que ocurre en el muro norte, los cuatro tramos occidentales del muro sur [UE 1056, 1365] de la nave mayor se rehacen y se refuerzan con contrafuertes [UE 1054, 1057, 1058, 1059]. La sillería es caliza, con sus aristas escantilladas y las juntas de unión gruesas. Se repite la partición del muro en una zona baja [UE 1365] y otra alta [UE 1056] por la introducción de los tirantes de Menéndez Pidal (Periodo VI). De los contrafuertes, el más oriental [UE 1054] se adosa al muro en su parte baja, mientras es solidario con la obra [UE 1056] en las últimas hiladas, relación que no es de extrañar si se considera este refuerzo incluido en este momento de restauración. Los dos siguientes contrafuertes hacia Occidente [UE 1057, 1058] confirman la misma secuencia, siendo sus zonas bajas aún originales (Periodo IIa) y las altas parte de la restauración y enderezamiento del muro. De hecho, el contrafuerte UE 1058 requiere una labor de engarce [UE 1059] realizada en sillares de arenisca de tono ocre que rompe el ritmo de las hiladas. Este mismo contrafuerte coincide al interior con una semicolumna [UE 1336] que, como ocurría en el muro norte, marca el límite de la ruina. Como su pareja septentrional [UE 1150], este soporte es solidario con el muro [UE 1365] solo desde la imposta.

La cubierta del tramo occidental de la nave central se dotó igualmente de tres arcos fajones [UE 1368] y comenzó la reconstrucción en sillería de la bóveda [UE 1369] (Fig. 32). Las marcas de cantero de los primeros y su situación sobre los muros longitudinales reconstruidos nos llevan a situarlos en este momento. Los arranques de las bóvedas deben entenderse dentro de la misma secuencia, pero no podemos confirmar su relación con el plemento central en ladrillo, por lo que se puede plantear un problema: arranques de sillería y plemento de ladrillo son coetáneos, reutilizándose material de la primera bóveda; sillería y ladrillo son de distintos momentos, lo que obligaría a pensar en una segunda ruina. No hay que olvidar la dificultad de su observación así como las pinturas modernas y contemporáneas que cubren la bóveda y, por tanto, las relaciones entre los elementos.

Por último, incluimos dentro de este Periodo IIc la inscripción tallada [UE 1361, A 208] en un sillar de la tercera hilada del segundo tramo occidental del muro sur
(Figs. 23 y 38), la cual reza: " $\operatorname{Pr}($ a)esul Petre laces IDS hic tra(n)slat(u)s ap(r)ilis", traducido "El obispo/prelado Pedro Jaqués, fue trasladado aquí el 15 de abril"41. Esta inscripción parece corresponder a la mencionada por Gómez Moreno (1925: p. 212), quien la atribuye al obispo D. Pedro, fallecido en 1112, cuyo lugar de sepultura se ignora.

\section{Consideraciones generales sobre el Periodo IIC}

Como hemos expuesto en el Periodo IIa, el estudio de la fábrica atribuida al Periodo IIc permite subrayar algunos puntos frecuentemente debatidos y otros completamente ignorados en la historiografía y aportar una nueva explicación.

- Bóvedas de ladrillo en los tramos occidentales. La restauración de Torbado a inicios del siglo XX no parece que afectase ni a las cuatro bóvedas occidentales de las naves laterales y ni a la bóveda de la nave mayor. Completamente ocultas por los enfoscados históricos y actuales, sabemos gracias a Gómez Moreno (1925: p. 189) que estas bóvedas están realizadas con baldosas de ladrillo de 0,25 m. Según Díaz-Jiménez (1917: p. 91), "llamó la atención del ilustre arquitecto leonés D. Juan Bautista de Lázaro ${ }^{42} \mathrm{el}$ agrietado que se notaba en el enlucido que cubría parte de la bóveda de la nave central; la gran hienda abierta en la falsa bóveda del coro, y el movimiento iniciado en algunas de las que cerraban la nave menor de la Epístola". El mismo Díaz-Jiménez recopila varias de las obras de Torbado, pero no menciona, al igual que Gómez Moreno (1925), actuación alguna sobre las bóvedas del aula.

La falta de referencias a una posible restauración por parte de Torbado por los investigadores inmediatos al momento ${ }^{43}$ y la secuencia estratigráfica fuerzan a admitir la erección de las bóvedas de ladrillo en una fase de reforma antigua (Periodo IIc), la cual optó por unas cubiertas más ligeras para minimizar las cargas excesivas que habían provocado la ruina previa. Las nuevas cubiertas de las naves laterales se elevan sobre unos arcos diafragma también reconstruidos, como muestran sus cortes, saltos y distintivas marcas de cantero. Únicamente sus arranques, solidarios con los muros, resistieron la ruina.

\footnotetext{
41 Trascripción y traducción que agradecemos a H. Gimeno (Centro CIL II, Univ. Alcalá de Henares, Madrid).

${ }^{42}$ Encargado de las obras antes de caer enfermo y ser sustituido por el arquitecto D. Juan Crisóstomo Torbado (Mélida 1910: p. 150).

43 Tampoco encontramos ninguna mención en Quadrado y Parcerisa (1855: p. 341), quienes visitan el edificio antes de las restauraciones de finales del XIX y hablan de las "bóvedas de las tres naves, así las laterales como la elevada y esbelta del centro, aunque de plena cimbra según deja suponerse, se distinguen por su gallardía".
} 
Como argumento indirecto, se puede añadir el uso del ladrillo también en la reparación del tímpano interior de la Portada del Cordero. Bóvedas de los cuatro tramos occidentales y tímpano son los únicos elementos del edificio románico ejecutados en material latericio.

Subrayar por último cómo casi ningún autor contemporáneo ha reparado en estas cubiertas y su posible datación ${ }^{44}$, siendo obviadas en las distintas propuestas (Fig. 1) sobre la historia del edificio y, con ellas, la restauración (IIc).

- La Portada del Cordero: iconografía, estratigrafía y cronología. La singularidad de la portada meridional del aula de San Isidoro de León ha dado lugar a una extensa bibliografía sobre la iconografía, el significado y la cronología de su tímpano y cuerpo de portada. La homogeneidad o heterogeneidad de su temática se basa en un aspecto que ha pasado, sin embargo, desapercibido para la investigación: el origen de las piezas decoradas que lo componen. Tres interpretaciones principales se han planteado al respecto: la realización de todas las piezas ex profeso para la portada ${ }^{45}$, la reutilización de las piezas y relieves decorativos que rodean la puerta ${ }^{46} \mathrm{o}$ la reutilización de todas las piezas de la portada, es decir, las que enmarcan la puerta y el tímpano ${ }^{47}$. Esta última propuesta apenas ha gozado de protagonismo. Únicamente Sauerländer (1966: pp. 263-264 y 286, n. 16) afirmó breve pero rotundamente que los ángeles del tímpano fueron recortados de una placa originalmente rectangular, según el modelo de la Porte Miégeville de Saint Sernin (Toulouse, Francia), y readaptados a su nuevo emplazamiento. Las juntas irregulares de las placas que forman el tímpano, la errónea dirección de la mirada de los ángeles hacia arriba y los cortes efectuados en los pies y en el nimbo del ángel de la derecha fueron sus principales argumentos.

\footnotetext{
44 Gudiol y Gaya (1948: p. 190) opinan que son originales, empleando el ladrillo como recurso para reducir el peso. Ignoramos porqué afirman que siete de las ocho bóvedas de aristas son de ladrillo, dejando una fuera.

45 Moralejo (1977), Williams (1977), Bango (1989: p. 149), Martin (2003) y Poza (2003), entre otros. Herráez, Cosmen y Valdés (2013) identifican tres talleres en su ejecución.

46 Con múltiples matices entre las propuestas. Díaz-Jiménez (1917: pp. 81-82), Gómez Moreno (1925: p. 197 y 1934: p. 64), Camps (1935: p. 45), Gaillard (1938: p. 67), Muir Whitehill (1939: p. 153), Pijoán (1944: p. 115), Gudiol y Gaya (1948: p. 192), Durliat (1964: p. 85), Enríquez de Salamanca (1990: p. 53) y Bango (1997: p. 120), entre otros.

47 Próxima a esta opción está la de Quadrado y Parcerisa (1855: p. 340), quienes apuntan la posibilidad de que la portada sea de una "época más reciente", del siglo X u XI, por el estilo de las piezas del tímpano y las figuras que le rodean. Sasoner (1908: p. 81) opina que la pieza del "Sacrificio de Isaac" es el frente de un sarcófago romano reutilizado por su belleza, pero no por su significado, el cual no se relaciona con el de las piezas superiores. Mayeur (1908) afirma, respondiendo al anterior, que el tímpano es una representación completa del capítulo 22 del Génesis.
}

Los indicios reconocidos por Sauerländer (1966) y rechazados por Williams (1977), quien prima la coherencia temática sobre la realidad material de las piezas ${ }^{48}$, han sido confirmados por el análisis, el cual aporta además un contexto para la portada. La ruina, grosso modo, de la mitad occidental de la basílica dio paso a una restauración que planifica este sector mediante la reconstrucción de las cubiertas abovedadas en ladrillo, la introducción de nuevos elementos, como los contrafuertes y ventanas de esta misma fachada sur, y la reelaboración de una nueva portada con una pieza monolítica ("Sacrificio de Isaac") que determina la colocación de las restantes piezas reutilizadas, cuyo origen pudo, o no, estar en una puerta previa.

Las propuestas sobre su cronología no deben perder de vista las emitidas sobre la evolución general del edificio, por lo que de nuevo están en una amplia horquilla que se mueve entre finales del siglo XI y primera mitad del XII (Fig. 1). Los estudios iconográficos sobre esta puerta, que seguro serán aún numerosos, deben considerar la reutilización de estos elementos, los cuales forman una portada alzada en un momento de reforma del edificio, para el cual sí parece que se talló el "Sacrificio de Isaac", hecho que conlleva implicaciones cronológicas e interpretativas, pues el contexto histórico es otro ${ }^{49}$.

\section{Interpretación y cronología}

La ruina de la mitad occidental de la basílica (Periodo IIb) fue reparada con un estilo similar al que caracteriza a la basílica románica (Periodo IIa), pero con variantes estilísticas y tipológicas que permiten pensar en un periodo posterior, como también ratifica la secuencia estratigráfica. Por estos motivos, no debió transcurrir mucho tiempo entre la ruina de la obra basilical y su reparación. De hecho, aunque se reconstruye siguiendo el formato de la fábrica románica (Periodo IIa), se reutilizan materiales y se emplean herramientas propias (gradina) de un momento

\footnotetext{
48 Aunque Williams (1977) databa esta portada en época de Alfonso VII (ca. 1142), en un postcriptum (Williams 2003: p. 179) a la traducción castellana de ese trabajo, acepta la fecha de ca. 1100 para el Tímpano del Cordero, defendida por otros investigadores, dentro del marco de la denominada Reconquista. Después de Williams (1977), el trabajo de Sauerländer (1966) "desaparece" de la bibliografía dedicada a la Puerta del Cordero.

${ }^{49}$ Uno de los evaluadores de este trabajo nos propone las siguientes notas. Primero, la posibilidad de que la pieza del "Sacrificio de Isaac" esté también reutilizada. Como hemos indicado, no apreciamos huellas de reutilización en ella, por lo que no nos atrevemos a confirmar esta propuesta. Segundo, que el tímpano de la Puerta del Perdón sea del año 1149, no de inicios del XII. Sus razones, suponemos que estilísticas e iconográficas, las ignoramos, por lo que tampoco podemos discutirlas. Por último, nos indica una descripción e imagen de G. E. Scott (1914) sobre este tímpano, a las cuales lamentablemente no hemos podido tener acceso. Le agradecemos en cualquier caso estas sugerentes notas, las cuales seguiremos considerando para futuros trabajos.
} 
más avanzado. Se adoptan medidas contra otra eventual ruina, como demuestran los dos macizos contrafuertes meridionales, de los cuales conservamos sus arranques, al oeste de la portada principal del aula, precisamente la zona afectada por la ruina (Fig. 3). Este muro se dota de ventanas, posiblemente como medio para iluminar una nave lateral obviamente oscura, pues sus únicas ventanas orientales estaban selladas desde el momento inmediato de su construcción. Por otro lado, los mechinales de los apuntalamientos que recorren en varias alturas toda la mitad oriental de la basílica están ausentes en la mitad occidental, la cual se arruinó y restauró, por lo que las huellas de los apuntalamientos actúan como negativo de la ruina y restauración del edificio.

Como ya observamos en el Periodo Ila, la historiografía tiende a reconocer diferentes momentos constructivos asociados a la secuencia dinástico-real recogida en las fuentes escritas. Como ya hemos apuntado, esta labor asume ciertos riesgos, pues si bien no se mencionan ruinas en la documentación escrita, ello no quiere decir que no existan, como demuestra por el contrario el análisis arqueológico del edificio. ¿Qué hacemos entonces con este nuevo periodo del edificio? Como hemos apuntado en las consideraciones cronológicas del Periodo IIa, la interpretación de las fechas y del término superaedificavit abre una serie de posibilidades: si tenemos en cuenta que el edificio es consagrado en el año 1149, durante el reinado de Alfonso VII, ¿se consagra la basílica concluida, siendo Pedro Diostamben el "responsable" de introducir el abovedamiento que a la postre provocó la ruina del edificio? o, por el contrario, ¿se consagra una basílica ya reparada por él con bóvedas de ladrillo?

Las referencias a una ruina por parte de la historiografía son escasas, aunque coincidentes. El arquitecto Lampérez (1908-09: p. 461) es uno de los pocos en anotar cómo el contrarresto de las naves laterales fue ineficaz ante una bóveda tan alta como la central, lo que provocó "un desequilibrio que ha dado por resultado el desplome de los pilares", argumento por el que confirma la pertenencia del transepto y la cabecera a la obra de Fernando I y su hija Urraca y el aula, por su atrevimiento estructural, a Alfonso VII. Para Gómez Moreno (1925: p. 189), son los sillares reutilizados en el muro sur, sus estribos, el trazado más próximo de los cuatro pilares occidentales y la introducción de columnas en el segundo desde el este, la evidencia de la reforma de una ruina en época de Alfonso VII. A ello añade (Gómez Moreno 1934: p. 105) la estrechez de las ventanas bajas y la diferencia de las ventanas y capiteles altos, aunque lo atribuye a finales del siglo XI. Camps (1935: p. 76) prefiere hablar de un derribo controlado, atribuyendo a una tercera fase los cuatro tramos occidentales con sus contrafuertes meridionales, ventanas menores y dos accesos nuevos, la Puerta del Cordero y la del panteón.

A estas opiniones, sumamos ahora los argumentos estratigráficos expuestos aquí y otro adicional. La capilla nordeste, conocida como de la Santísima Trinidad y fuera del ámbito de nuestro análisis, se fecha tradicionalmente en el año 1190 de acuerdo a un epígrafe que recorre la rosca del arco de su portada septentrional (Gómez Moreno 1925: p. $\left.191^{50}\right)$. De ser cierta esta fecha, la relación de adosamiento de esta capilla al ábside norte de la basílica y a sus mechinales de apuntalamiento, efectuados para defenderse de la posible ruina, estrecharía el paréntesis del proceso de restauración en esta segunda mitad del siglo XII.

\section{Consideraciones generales sobre el Periodo II}

Dada la importancia de la obra románica de San Isidoro, es necesario valorar los nuevos datos ofrecidos por el análisis arqueológico. Entre los numerosos temas que se abren a la luz de los resultados obtenidos, podemos detenernos en algunos que consideramos relevantes para una eventual investigación de la basílica y del románico en general:

- Las marcas de cantero (Fig. 24). Gómez Moreno (1925: p. 188) recurrió a los tipos de marcas para argumentar las dos etapas que, por motivos arquitectónicos e históricos, veía en el edificio. La primera, atribuida a finales del siglo XI, se definiría por la presencia de marcas de "hechura de letras generalmente, entre ellas la W, $\mathrm{y}$, además, en un solo sillar aparecen estas: VDO; hay también una ballesta, flecha, cuchilla y signos convencionales muy escasos". La segunda, situada dentro de un largo siglo XII, tendría "más signos convencionales, un jarro, letras como siempre, y el grupo F-S-J". De hecho, Gómez Moreno (1934: p. 104) ya anota la similitud de las marcas de cantero del transepto de San Isidoro con las de la Catedral de Santiago de Compostela, interpretando el ejemplo leonés como el lugar de aprendizaje de los canteros que posteriormente marcharían a trabajar a Santiago. Relación que tanto Williams (1984: pp. 286288) como Martin (2005: p. 381) invierten, al considerar San Isidoro como el consecuente del modelo gallego por el mismo argumento de las marcas comunes.

El hecho de que las mismas marcas aparezcan en otros edificios que, aunque con cronologías similares,

\footnotetext{
50 "Cosecrata fuit hec ecla era MCCXXVIII et quotum VII". Como hizo notar García Lobo (1987: pp. 394-396), está inconclusa (“Fue consagrada esta iglesia el año 1191, precisamente el día ...”).
} 
no tienen por qué ser coetáneos, invalida la idea de un mismo cantero trabajando en distintos lugares. Posiblemente le correspondía al "jefe de obra" (Alexander 2007: p. 65) otorgar una marca o signo de autoría y controlar así el volumen de piedra tallada por cada cantero. Se refleja así la participación de canteros que cobran por el número de sillares elaborados, cuya cuidada talla permitiría ajustar las juntas, disponer hiladas regulares y horizontales, crear sillares estandarizados, como los de los pilares cruciformes (los únicos con marcas de posición e intercambiables) o ciertos elementos decorativos (como los frisos y las cornisas) y, en definitiva, agilizar la construcción. Todos estos elementos (sillería, marcas, estandarización) evidencian un proceso de profesionalización y organización de la obra que se consolidará durante el siglo XII (Kimpel 1980 y Stalley 1999: pp. 106-107). El incremento de la sofisticación repercutirá en la organización del trabajo y en el status del constructor, donde debemos recordar la presencia de la figura de Pedro Diostamben en la inscripción.

Esa especialización también se puede leer en las marcas, siendo los elementos decorativos y los tambores de los pilares cruciformes firmes indicadores. Los primeros, en los que se incluyen impostas y capiteles, no requieren marcas de cantero, siendo su estilo la firma del maestro decorador. Hay que considerar la probable elaboración de estas piezas en un taller y su emplazamiento posterior en el edificio, lo que haría aún más innecesaria el sello del artista. Por el contrario, los tambores de los pilares, cuya puesta en obra y talla final exigen una notable precisión, presentan gran número de marcas de autoría específicas propias a la vez que marcas de posición, estando gran parte de las semicolumnas recorridas por una línea vertical que marca el eje central y la coordinación entre las piezas para su correcta colocación.

En este análisis no debemos olvidar que, sin embargo, ignoramos si la marca corresponde a un único cantero (individuo) o a un grupo (taller), por lo que su capacidad informativa sobre el número de canteros trabajando es limitada. También ignoramos por qué hay un gran número de sillares que, siendo de la misma etapa, carecen de marcas. No se puede concluir de ello que estas piezas no fuesen pagadas, pero tal vez lo fueron de otra manera ${ }^{51}$. También es muy significativo que la obra de restauración del Periodo IIc se ve posiblemente

\footnotetext{
51 Como por ejemplo concluye Rodríguez Estévez (1998: p. 262) a partir del estudio de la Catedral de Sevilla (siglo XV), apuntando que los sillares sin marca eran pagados por el sistema de jornal, mientras que los marcados eran producto del trabajo a destajo.
}

sometida a un ritmo de urgencia, como evidenciaría el notable incremento del número de las marcas de cantero, probable indicio de un trabajo a destajo que pretende y necesita acelerar el final de la obra con la intención de reparar un edificio inestable como consecuencia de su ruina parcial.

Del mismo modo que la obra del Periodo I carece de marcas y, por ello, puede ajustarse sin problemas a una cronología de mediados del siglo XI, la obra del Periodo II cuenta con ellas desde su inicio, el cual, de acuerdo a las cronologías más tempranas que se barajan sobre el empleo de las marcas de cantero (Moralejo 1996, Alexander 2007 y Esquieu y Hartmann-Virnich 2007), no pudo tener lugar antes de la última década del siglo XI.

- Maestros, escultura y estratigrafía. Mientras las distintas propuestas evolutivas sobre el edificio son numerosas, la lista se reduce en cuanto al análisis de las decoraciones. Como iglesia situada en el Camino de Santiago, su relación con algunos de los templos localizados en este itinerario de peregrinaje se ha planteado claramente desde un principio, siendo las catedrales de Jaca (Huesca, principalmente por la presencia de impostas taqueadas) y la de Santiago de Compostela ( $\mathrm{La}$ Coruña, por las portadas) sus habituales referentes.

Es precisamente la evolución del conjunto compostelano la que de una manera más o menos directa ha influido en la comprensión de cuerpo decorativo de San Isidoro y, por ende, de su evolución constructiva. Aunque todos los autores coinciden en identificar dos o tres artistas como autores de las piezas decorativas, su relación con Santiago ha introducido notables variables. De este modo, se establece una estrecha vinculación con el maestro Esteban de la Puerta de las Platerías compostelana, el cual bien habría aprendido en San Isidoro antes de marchar a Santiago (Gómez Moreno 1934: p. 110 y Camps 1935: p. 78), bien, por el contrario, una vez acabada su labor en Santiago habría venido a San Isidoro (Martin 2007: p. 129). Siguiendo con esta línea argumentativa, recordamos que, lógicamente, para Gómez Moreno y Camps el transepto pertenecería a la obra de la infanta Urraca (1072-1101), mientras que Martin lo atribuye a la reina Urraca (1109-1126). Todos ellos coinciden, sin embargo, en que la Puerta del Perdón, o sur del transepto, es posterior a la Puerta del Cordero, o sur de la nave ${ }^{52}$. Un tercer maestro, relacionado con la obra de Pedro de

\footnotetext{
52 Como también opina Pijoán (1944: p. 117) o, recientemente, Herráez, Cosmen y Valdés (2013). Solamente McCluskey (1994: pp. 42 y 46) dilata esta secuencia al atribuir la Puerta del Cordero a Fernando I y la del Perdón al citado maestro Esteban. Otras opiniones en Fig. 1.
} 
Deustamben, actuaría en la primera mitad del siglo XII, en opinión de Camps (1935: pp. 78 y 83).

Es indudable que un edificio con las dimensiones y el prolongado proceso constructivo de San Isidoro debió contar con una nutrida plantilla de canteros, como demuestra la variedad y dispersión de las marcas, y de canteros especializados o decoradores, cuya firma en este caso es su propio estilo. Tanto capiteles como impostas y cimacios no tuvieron porqué ser tallados a pie de obra, pudiendo provenir de talleres fijos o itinerantes.

Pero lo que realmente pone de manifiesto el análisis arqueológico es que todos estos artesanos y/o talleres trabajaron para un mismo proyecto constructivo que avanzó de manera homogénea. Una vez alzado su perímetro, prosiguió en altura sus naves laterales para finalmente ser abovedado. La ausencia de fases constructivas marcadas por interrupciones hace del conjunto de estos artesanos un grupo que trabaja de modo coetáneo, aunque ello implique cincuenta años de construcción y diferentes manos y estilos.

- La construcción en marcha. De acuerdo a los datos expuestos, carece de relevancia en el momento actual argumentar una construcción que se origina de oeste a este o viceversa, pues el análisis nos demuestra cómo nos encontramos ante una construcción concebida de manera orgánica. Las líneas se trazan desde occidente, siguiendo las establecidas por la obra del Periodo I, y desde oriente contemplando ya una zona destinada a transepto y cabecera. De hecho, la diagonalidad de las juntas de obra indicadas evidencia cómo las hiladas del este se montan sobre las del oeste, se coloca la imposta como elemento unificador y se vuelve a empezar. La construcción va alzándose así al mismo tiempo, siendo las únicas diferencias entre las etapas 1 y 2 de este Periodo IIa la posición de los mechinales (abiertos en hiladas bajas la primera, tallando los ángulos de los sillares la segunda). Una vez creado este perímetro, se cierra el muro norte y se procede al abovedamiento de las naves laterales y de la central. Es ahora cuando tiene lugar el cambio de proyecto, el cual justificaría la anómala presencia de columnas que amortizan las ventanas para sujetar las respectivas cubiertas abovedadas y el remate en ménsula del arco fajón correspondiente de la bóveda de la nave mayor. Este cambio de proyecto se produjo en marcha, como intuyó Gómez Moreno (1934: p. 104), sin que podamos confirmar cómo se pensaba cubrir o abovedar el plan primitivo, aunque consideramos la cubierta de madera como la opción más probable. En este sentido, nuestras propuestas no pasan de ser simples conjeturas.

No sabemos el tiempo qué transcurrió, pero posiblemente muy poco después de su puesta en carga, las diferencias de luz y altura de las naves central y laterales provocaron la ruina de algo más de la mitad occidental de la basílica (Periodo IIb). Los soportes se giraron y los muros se abrieron hacia afuera, requiriéndose refuerzos que evitasen que la ruina fuese a más. Las huellas de los apuntalamientos conservados en la mitad oriental, no venida abajo, evidencian el miedo hacia ese proceso de ruina y el intento de buscar un medio de estabilidad.

La reparación (Periodo IIc) no se hizo esperar, como pone de manifiesto el estilo románico de esta obra. El retalle de las marcas y su abundancia reflejan el apremio en reformar las partes perdidas, mientras que las cubiertas de ladrillo pretenden minimizar los empujes que causaron la ruina previa. Se refuerza con gruesos contrafuertes el muro sur, carente de los contrarrestos del septentrional, y se reconstruye la portada perdida empleando piezas antiguas y nuevas.

Sin embargo, la inestabilidad estable de San Isidoro no se resolvió con las cubiertas de ladrillo que, a pesar de ser más ligeras, se vieron forzadas a continuar la geometría y altura de sus precedentes, por lo que heredaron los problemas de la estructura previa. De hecho, Viñayo (2007: p. 94) no duda en creer que el coro occidental del siglo XV, el claustro del XVI y los refuerzos de los contrafuertes meridionales pretendían amortiguar los movimientos estructurales atando y reforzando los distintos elementos.

\section{Notas Finales}

El análisis arqueológico individualiza periodos, no ofrece cronologías concretas, por lo que no podemos responder a la cuestión de las autorías, cuya respuesta ha movido normalmente la investigación de San Isidoro. Las características de esos periodos no permiten afirmar, por ejemplo, si estamos en el año 1100 o en el 1110, paréntesis que diferencia al fin y al cabo el infantado de Urraca (1072-1101) del reinado de la segunda Urraca (1109-1126). Pero sí creemos que el análisis puede modificar la lectura de los documentos escritos de acuerdo a los resultados obtenidos, el cual deberá ser llevado a cabo por especialistas.

La documentación textual atribuye a los monarcas Fernando I (1037-1065) y Sancha (m. 1067) la construcción de una iglesia previa a la actual. La inscripción es 
el primer elemento digno de un estudio pormenorizado por un epigrafista, que analice no solo la veracidad de la información, sino además las fórmulas empleadas con el objetivo de afrontar de un modo riguroso el problema de la autoría de la propia inscripción. Por otro lado, el análisis arqueológico documenta en el ángulo noroeste del aula de la basílica los restos de un conjunto alzado con paramentos de sillería y dotado de dos accesos, uno septentrional y otro occidental. Ya hemos anotado los problemas de reconstrucción en alzado (cubiertas) y en planta (ausencia de retranqueos de los muros) de esta estructura. Del mismo modo, hemos confirmado que los muros atribuidos a ella no corresponden con los hallados en excavación, los cuales parecen pertenecer a una construcción previa, posiblemente de época romana, a tenor de las excavaciones efectuadas en el entorno inmediato, reutilizada como cimentación de una nueva obra. Sobra decir que ignoramos la secuencia estratigráfica entre ambos (muros en alzado y vestigios en subsuelo), por lo que poco o nada podemos aportar a su cronología. Solo una nueva apertura del suelo y un detallado análisis de la relación entre los muros en alzado y los vestigios exhumados por Torbado resolverían con certeza esta relación.

Respecto a la basílica románica, podemos afirmar que se construye desde ambas direcciones, como delatan los andamios (posición de mechinales) y las juntas de obra, perteneciendo el transepto al proyecto primitivo. Los distintos datos expuestos permiten argumentar que no se trata de un espacio añadido, sino de un espacio unitario a la basílica, la cual asiste, sin embargo, a un cambio de proyecto en marcha que introduce el abovedamiento, hecho que explica ciertas anomalías, como la posición de la pareja de columnas delante de las ventanas del tramo oriental. Se constata igualmente la existencia de una estructura construida a los pies, comunicada con la basílica gracias a un vano alto, relacionable con el palacio de las fuentes.

La ruina del edificio interrumpe en la secuencia textual. Detectada en el primer análisis (Murillo 2006) ${ }^{53}$, se consideró entonces como "superficial", pero los indicios ahora observados en toda la basílica permiten afirmar que esta ruina es estructural e identificar los límites de su alcance. Parece que la puesta en carga del edificio al erigir la bóveda central supuso la caída de su mitad occidental. El hecho de que la altura de la bóveda central duplique la de las laterales (17 $\mathrm{m}$ frente a 8,5 $\mathrm{m})$ impide que los muros de $1 \mathrm{~m}$ de grosor de la nave mayor funcionen de modo efectivo. El muro norte del aula resiste porque está contrarrestado por el claustro, mientras que el sur, libre de refuerzos, dobla por encima de la imposta baja tanto al interior como al exterior. La ruina se observa en las roturas de soportes (columnas de la nave central) y en los saltos de los paramentos y arcos diafragma.

La reconstrucción se producirá de forma inmediata, reutilizando parte de la sillería, trabajando con rapidez, posiblemente "a destajo" (como evidencian las abundantes marcas de cantero y los retalles de algunas de ellas), e introduciendo potentes contrafuertes en el muro sur, así como apuntalando aquellas partes del edificio que no se habían arruinado. Obviamente, si nunca se había documentado una ruina, tampoco su reconstrucción, siendo por ello ambas una novedad en la historia del edificio. La ruina permite explicar, fundamentalmente, dos aspectos. Primero, la presencia de bóvedas de ladrillo en los tramos occidentales, apenas tratadas por la investigación sino en un intento de explicarlas como una medida efectiva estructural de la basílica original. Estas nuevas bóvedas reemplazan a las primitivas de piedra con el objetivo de descargar el edificio. Segundo, la organización de la Portada del Cordero, con un tímpano, soportes y cuerpo adelantado compuestos en realidad de piezas nuevas y reutilizadas, provenientes posiblemente de una misma puerta previa en el lugar. Este hecho ya se documentó en el primer análisis del edificio (Murillo 2006) $)^{54}$, siendo ahora contextualizado dentro de los procesos de ruina y reconstrucción indicados. Esta evidencia tiene notables implicaciones para su lectura e interpretación histórica e iconográfica, las cuales deben ser planteadas teniendo en cuenta la secuencia estratigráfica aquí identificada.

Como ya hemos dicho, tanto la ruina como su reconstrucción irrumpen en la secuencia textual y obligan a una relectura de los indicadores cronológicos conocidos. Cronológicamente, como ampliación de la obra del Periodo I, las fechas de 1063/1067 son un post quem obvio. A ellas se suman tres indicios a tener en cuenta en la datación de la basílica románica. Primero, el discutido término amplificavit referido en las fuentes sobre la infanta Urraca (1072-1101), quien habría patrocinado la ampliación de la obra de sus progenitores, sin olvidar la discusión que afecta al panteón, espacio no analizado en este trabajo. Segundo, la inscripción con 
fecha 1124 (Era 1162) situada en el ábside norte, considerada funeraria por algunos investigadores y, por ello, posiblemente más tardía, o de fundación, por otros. En nuestra opinión, la primera opción cobra fuerza teniendo en cuenta la posición anómala que ocupa y la ausencia de mención del autor de la obra en la inscripción si se la atribuye un carácter fundacional. Tercero, el también debatido término superaedificavit de la inscripción de Alfonso VII, con consagración en el año 1149 y la figura de Pedro de Deustamben. Y por último, la inscripción funeraria que menciona el traslado del obispo prelado Pedro Jaqués, tallada en el muro meridional, efectuada en un momento posterior a 1112. A ello se añade un último dato. La Capilla de la Santísima Trinidad, situada en el lado norte de la cabecera y también fuera de nuestro estudio, se alza en el año 1190 según la inscripción de su acceso meridional, y se adosa a los apuntalamientos de los muros que evitaron la ruina de esta zona.

Sin embargo, la presencia de huellas de gradina o trinchante, una herramienta cuyo uso no parece emplearse antes de un momento avanzado del siglo XII, difundiéndose notablemente en las grandes obras de época gótica, se destapa como un indicador cronológico que parece situar la gran reforma de la basílica (Periodo IIc), donde incluimos la Puerta del Cordero, en la segunda mitad del siglo XII ${ }^{55}$. Es decir, proponemos como posibilidad que en los años finales del reinado de Alfonso VII (1126-1157), Pedro de Deustamben proyectase las bóvedas de piedra, teniendo en cuenta el término de $s u$ peraedificavit, el cual reflejaría la decisión de abovedar un edificio que no estaba preparado para ello. La basílica se consagraría en el año 1149, teniendo lugar la ruina poco después. La restauración ya en época de Fernando II (1157-1188) optó por introducir bóvedas de ladrillo, a priori más ligeras, aunque la basílica arrastrará riesgos estructurales hasta nuestros días.

El análisis arqueológico de San Isidoro demuestra cómo su historia se hace más compleja y completa al añadir capítulos inéditos a la historia escrita desde las fuentes textuales. Estas hablan de varias generaciones de promotores actuando en las obras a lo largo de un periodo de tiempo indeterminado que parece iniciarse con Urraca en las últimas décadas del siglo XI y concluir, en primera instancia, a mediados del siglo XII con Alfonso

\footnotetext{
55 Herramienta también denominada trinchante. Según los estudios de Bessac (1986: p. 67) en ámbito francés, quien la denomina bretture, es siempre identificable por dejar una huella dentada en línea. Para España no contamos con trabajos tan precisos, pero los escasos indicios obtenidos parecen refrendar fechas similares.
}

VII. Los muros, por su parte, nos dicen que también fueron varias las generaciones de técnicos, canteros, escultores, etc. que trabajaron en San Isidoro en tres impulsos edilicios consecutivos y que tuvo lugar una ruina que conllevó una profunda reforma de la configuración original del edificio.

\section{Agradecimientos y Ficha técnica}

Análisis arqueológico encargado y financiado por el Servicio de Restauración de la Junta de Castilla y León, realizado en dos fases. Equipo de 2006: L. Caballero, arqueólogo (IH-CSIC); J. I. Murillo, arqueólogo; F. Arce, historiador del arte (CCHS-CSIC); F. Peláez, historiadora del arte (IH-CSIC), I. Monteira, historiadora del arte (IHCSIC); y J. M. Lucena, arqueólogo. Equipo de 2008: J. I. Murillo; F. Arce (CCHS-CSIC), M. á Á. Utrero, arqueóloga (IH-CSIC) y R. Martín Talaverano, arquitecto. Planimetría original: J. J. Fernández Martín (ETSA-UVA) y J. San José Alonso (ETSA-UVA). Tratamiento de la planimetría: R. Martín Talaverano, arquitecto, y E. Ducar Martínez, restituidora. Agradecemos la ayuda de: F. Rodríguez Llamazares, abad de la Colegiata; C. Redondo, directora del Museo de la Real Colegiata de San Isidoro; R. Cañas, arquitecto; C. Sexmilo, arquitecto; y C. Gutiérrez, DECOLESA. Supervisión: M. Gómez Barreiro, Servicio de Restauración, Junta de Castilla y León.

Todas las figuras reproducidas en este trabajo son propiedad de los autores, a excepción de las figuras 3 , $4,5,6,8,20,23,27$ y 32 , las cuales son el resultado de la suma de la planimetría original y tratada (ver autores arriba) y posteriormente finalizada y maquetada por los autores; y de las figuras 15, 16, 18 y 35, tomadas de las obras referenciadas entre paréntesis en el pie de figura correspondiente y tratadas igualmente por los autores.

\section{Bibliografía}

Alexander, J. S. 2007: “The Introduction and Use of Masons' Marks in Romanesque Buildings in England", Medieval Archaeology, 51, pp. 63-81.

Bango Torviso, I. 1989: Alta Edad Media. De la tradición Hispanovisigoda al Románico. Silex, Madrid.

Bango Torviso, I. 1992: "El espacio para enterramientos privilegiados en la arquitectura medieval española", Anuario del departamento de Historia y Teoría del Arte, 4, pp. 93-132.

Bango Torviso, I. 1997: El arte románico en Castilla y León. Banco de Santander, Madrid.

Bessac, J.-C. 1986: L'outillage traditionnel du tailleur de pierre. CNRS, Paris.

Boto Varela, G. 2007: “Arquitectura medieval. Configuración espacial y aptitudes funcionales", en Robles, C. y Llamazares, F. (coords.): Real Colegiata de San Isidoro. Relicario de la monarquía leonesa, pp. 51-103. Edilesa, León. 
Boto Varela, G. 2009, "Morfogénesis espacial de las primeras arquitecturas de San Isidoro. Vestigios de la memoria dinástica leonesa", en Siete maravillas del románico español, pp. 151-191. Fundación Santa María la Real, Aguilar de Campoo.

Caldwell, S. H. 1986: "Urraca of Zamora and San Isidoro in León: Fulfillment of a Legacy", Woman's Art Journal, 7/1, pp. 19-25.

Camps Cazorla, E. 1935: El arte románico en España. Labor, BarcelonaMadrid.

Conant, K. J. 1959: Carolingian and Romanesque Architecture, 800 to 1200. Penguin Books, Hardsmonth.

Díaz-Jiménez y Molleda, J. E. 1917: "San Isidoro de León”, Boletín de la Sociedad Española de Excursiones, XXV, pp. 81-98.

Durliat, M. 1964: El arte románico en España. Juventud DL, Barcelona (1ª ed. Paris, 1962).

Durliat, M. 1990: La Sculpture Romane de la Route de Saint-Jacques. De Conques à Compostelle. Comité d'Études sur l'Histoire et l'Art de la Gascogne, Mont-de-Marsan.

Enríquez de Salamanca, C. 1990: Rutas del Románico en la provincia de León. Cayetano Enríquez de Salamanca DL, Salamanca.

Esquieu, Y. y Hartmann-Virnich, A. 2007: "Les signes lapidaires dans la construction médiévale: études de cas et problèmes de méthode", Bulletin Monumental, 165/4, pp. 331-358.

Estepa, C. 1977: Estructura social de la ciudad de León (siglos XI-XIII). Centro de Estudios e Investigación "San Isidoro" Archivo Histórico Diocesano, León.

Fernández González, E. 1992: San Isidoro de León, Cuadernos de Arte Español vol. 53. Historia 16, Madrid.

Fernández González, E. 2009, "Reflexiones sobre la evolución hacia el Románico de las fórmulas artísticas altomedievales en el ámbito astur-leonés, de la undécima centuria", en Arbeiter, A., Kothe, C. y Harris, J. A. (eds.): Hispaniens Norden im 11. Jahrhundert. Christliche Kunst im Umbruch (Göttingen 2004), pp. 48-72. Michael Imhof Verlag, Petersberg.

Florez, H. 1765: Viage de Ambrosio de Morales por orden del rey D. Phelipe II a los reynos de León, y Galicia, y Principado de Asturias. Para reconocer Las Reliquias de los Santos, Sepulcros Reales, y Libros manuscritos de las Cathedrales, y Monasterios. Antonio Marín, Madrid. (Ed. Facsímil: Oviedo 1977).

Gaillard, G. 1938: Les débuts de la sculpture romane espagnole. Leon - Jaca - Compostelle. Paul Hartmann, Paris.

García y Bellido, A. 1970: "Estudios sobre la Legio VII Gemina y su campamento en León”, en Legio VII Gemina, pp. 569-599. Diputación Provincial, León.

García de Castro, C. 2006: La Colegiata de San Pedro de Teberga. Ediciones Nobel, Llanera.

García Lobo, V. 1987: "Las inscripciones medievales de San Isidoro de León. Un ensayo de Paleografía epigráfica medieval", en Santo Martino de León. I Congreso internacional sobre Santo Martino en el VIII centenario de su obra literaria (1185-1985), pp. 371-398. Isidoriana Editorial, León.

García Martínez, A. 2005: “Aproximación crítica a la historiografía de San Isidoro de León”, Estudios Humanísticos. Historia, 4, pp. 53-93.

Gómez Moreno, M. 1925, Catálogo monumental de la provincia de León. Ministerio de Instrucción Pública y Bellas Artes, Madrid.

Gómez Moreno, M. 1934: El arte románico español. Esquema de un libro. Centro de Estudios Históricos, Madrid.

Gudiol, J. y Gaya, J. 1948: Arquitectura y escultura románicas, Ars Hispaniae V. Plus Ultra, Madrid.

Gutiérrez González, J. A. 1999: “Génesis del urbanismo en la ciudad de León y su transformación en la Edad Media", en Valdés, F. (coord.), III Congreso sobre la Península Ibérica y el Mediterráneo entre los siglos XI-XIII: El Urbanismo de los Estados Cristianos Peninsulares (Aguilar de Campoo 1998), pp. 43-90. Fundación Santa María la Real, Palencia.

Herráez, M. ${ }^{\text {a } V ., ~ C o s m e n, ~ M . ~}{ }^{\text {a }}$ C. y Valdés, M. 2013: "La escultura de San Isidoro de León y su relación con otros talleres del Camino", De Arte. Revista de Historia del Arte, 12, pp. 41-58.

Kimpel, D. 1980: "L'apparition des elements de serie", Histoire et Archeologie, 47, pp. 40-59.
Lampérez y Romea, V. 1908-1909: Historia de la Arquitectura Cristiana Española en la Edad Media, según el estudio de los Elementos y los Monumentos, 2 vols. Blass, Madrid.

Martin, Th. 2003, "Un nuevo contexto para el Tímpano del Cordero en San Isidoro de León”, en Sánchez Ameijeiras, R. y Senra Gabriel y Galán, J. L. (coords.): El Tímpano Románico. Imágenes, Estructuras y Audiencias, pp. 181-205. Xunta de Galicia, Santiago de Compostela.

Martin, Th. 2005, "Reading the Walls: Mason's Marks and the Archaeology of Architecture at San Isidoro, León”, en Martin, Th. y Harris, J. A. (eds.): Church, State, Vellum, and Stone: Essays on Medieval Spain in Honor of John Williams, pp. 373-412. Brill, Leiden-Boston.

Martin, Th. 2006: Queen as King. Politics and Architectural Propaganda in Twelfth-Century Spain. Brill, Leiden-Boston.

Martin, Th. 2007, "Decorar, aleccionar, aterrorizar. Escultura románica y gótica", en Robles, C. y Llamazares, F. (coords.): Real Colegiata de San Isidoro. Relicario de la monarquía leonesa, pp. 104-143. Edilesa, León.

Martin, Th. 2008a: "Hacia una clarificación del infantazgo en tiempos de la reina Urraca y su hija la infanta Sancha (ca. 1107-1159)", e-Spania, 5, $17 \mathrm{pp}$.

Martin, Th. 2008b: "Recasting the concept of the "pilgrimage church": the case of San Isidoro de León", La Corónica. A Journal of Medieval Spanish Language, Literature \& Cultural Studies, 36.2, pp. 165-189.

Martin, Th. 2008c: "Una reconstrucción hipotética de la portada norte de la Real Colegiata de San Isidoro, León", Archivo Español de Arte, LXXXI324, pp. 357-378.

Mayeur, P. 1908: "Le symbolisme d'un tympan de porte à San Isidro de Léon", Revue de l'Art Chrétien, LI, pp. 250-253.

McCluskey, R. 1994: "The Early History of San Isidoro de León (X-XII c.)", Nottingham Medieval Studies, XXXVIII, pp. 35-59.

Mélida, J. R. 1910: "La Basílica legionense de San Isidoro", Boletín de la Real Academia de la Historia, LVI, pp. 148-153.

Menéndez Pidal, L. 1964: "La iglesia primitiva de San Juan Bautista y San Pelayo, de León", en Symposium sobre cultura asturiana de la Alta Edad Media (Oviedo 1961), pp. 71-78. Ayuntamiento, Oviedo.

Moralejo, S. 1977: "Pour l'interprétation iconographique du Portail de l'Agneau a Saint-Isidore de Leon: les signes du Zodiaque", Cahiers de Saint-Michel de Cuxa, 8, pp. 137-173.

Moralejo, S. 1985: "Artistas, patronos y público en el arte del Camino de Santiago", Compostellanum, XXX/3-4, pp. 395-430.

Moralejo, S. 1996: "Saint-Jacques-de-Compostelle. Les origines d'un chantier roman", en AA.VV., Chantiers médiévaux, pp. 127-143. Desclée de Brouwer, Paris.

Muir Whitehill, W. 1939: Spanish Romanesque Architecture of the eleventh century. Oxford University Press, Oxford.

Müller-Reissmann, F. 2009: "Die Kapitellskulptur von San Isidoro in León", en Arbeiter, A., Kothe, C. y Harris, J. A. (eds.): Hispaniens Norden im 11. Jahrhundert. Christliche Kunst im Umbruch (Göttingen 2004), pp. 212 219. Michael Imhof Verlag, Petersberg.

O'Keeffe, T. 2007: Archaeology and the Pan-European Romanesque. Duckworth Publishers, London.

Pérez Llamazares, J. 1927: Historia de la Real Colegiata de San Isidoro, de León. Imprenta Moderna, León.

Pijoán, J. 1944: El arte románico siglos XI y XII, Summa Artis IX. EspasaCalpe, Madrid.

Plötz, R. 1982: "Der Apostel Jacobus in Spanien bis zum 9 Jahrhundert", Gesammelte Aufsätze zur Kulturgeschichte Spaniens. Spanische Forschungen der Görresgesellschaft, 1. Reihe, 30, pp. 19-145.

Poza, M. 2003: "Entre la tradición y la reforma. A vueltas de nuevo con las portadas de San Isidoro de León", Anuario del Departamento de Historia y Teoría del Arte, XV, pp. 9-28.

Prado-Vilar, F. 2009: “Lacrimae rerum: San Isidoro de León y la memoria del padre", Revista de arte Goya, 328, pp. 195-221.

Puyol, J. 1926: Crónica de España por Lucas, obispo de Túy. Tipografía de la "Rev. Archivos, bibliotecas y museos", Madrid.

Quadrado, J. M. y Parcerisa, F. J. 1855: Recuerdos y Bellezas de España. Asturias y León, Madrid (ed. Facsímil: Ayala, Gijón 1977). 
Risco, M. 1786: España Sagrada, tomo XXXV. Oficina de Pedro Marín, Madrid. Risco, M. 1792: Historia de León. Tomo II: Iglesia de León, y monasterios antiguos y modernos de la misma ciudad. Oficina de Don Blas Román, Madrid (ed. Facsímil: León, 1978).

Robles, C. 2007: "Monasterio de San Isidoro. Fundación e Historia", en Robles, C. y Llamazares, F. (coords.): Real Colegiata de San Isidoro. Relicario de la monarquía leonesa, pp. 29-49. Edilesa, León.

Rodríguez Estévez, J. C. 1998: Los canteros de la Catedral de Sevilla. Del Gótico al Renacimiento. Diputación, Sevilla.

Sánchez Ameijeiras, R. 2005: "The eventful life of the royal tombs of San Isidoro in León”, en Martin, Th. y Harris, J. A. (eds.): Church, State, Vellum, and Stone: Essays on Medieval Spain in Honor of John Williams, pp. 479-519. Brill, Leiden-Boston.

Sasoner, G. 1908: "La Vie de Jésus Christ", Revue de l'Art Chrétien, LI, pp. 78-92 у pp. 241-248.

Sauerländer, W. 1966: "Über die Komposition des Weltgerichts-Tympanons in Autun", Zeitschrift für Kunstgeschichte, XXIX/4, pp. 261-294.

Seehausen, F. 2009: "Baugeschichte als dynastiches Konstrukt. Die Bauphasen und ihre Interrelation mit der Kapitellskulptur von San Isidoro in León”, en Arbeiter, A., Kothe, C. y Harris, J. A. (eds.): Hispaniens Norden im 11. Jahrhundert. Christliche Kunst im Umbruch (Göttingen 2004), pp. 200-211. Michael Imhof Verlag, Petersberg.

Stalley, R. 1999: Early Medieval Architecture. Oxford University Press, Oxford.

Suárez González, A. 2003: “¿Del pergamino a la piedra? ¿de la piedra al pergamino? (entre diplomas, obituarios y epitafios medievales de San Isidoro de León", Anuario de Estudios Medievales, 33/1, pp. 365-415.

Viñayo González, A. 1964: "La Real Colegiata de San Isidoro y la expansión del arte prerrománico asturiano", en Symposium sobre cultura asturiana de la Alta Edad Media, (Oviedo 1961), pp. 105-117. Ayuntamiento, Oviedo.

Viñayo González, A. 1978: "El arte románico leonés. Nuevas cuestiones”, en León Medieval. Doce estudios, pp. 219-232. Colegio Universitario, León.

Viñayo González, A. 2002: "Real Colegiata de San Isidoro", en García Guinea, M. Á. y Pérez González, J. M. (Dirs.): Enciclopedia del Románico en Castilla y León, León, vol. 11,pp. 534-566. Fundación Santa María la Real, Aguilar de Campoo.

Viñayo González, A. 2007: Real Colegiata de San Isidoro de León. Al filo de medio siglo de restauraciones y renovaciones 1956-2003. Cátedra de San Isidoro, León.

Walker, R. 1998: "Sancha, Urraca and Elvira: the virtues and vices of Spanish royal women 'dedicated to God"', Reading Medieval Studies, 24, pp. 113-138.

Walker, R. 2000: "The Wall Paintings in the Panteón de los Reyes at León: A Cycle of Intercession", The Art Bulletin, LXXXII/II, pp. 200-225.

Williams, J. 1971: "The Mystery of San Isidoro", Swarthmore. College Bulletin, X, pp. 11-14.

Williams, J. 1973: "San Isidoro de León: Evidence for a new History", The Art Bulletin, LV/II, pp. 170-184.

Williams, J. 1977: "Generationes Abrahae: Reconquest Iconography in Leon", Gesta, XVI/2, pp. 3-14.

Williams, J. 1984: "La arquitectura del Camino de Santiago", Compostellanum, XXIX/3-4, pp. 267-290.

Williams, J. 1993: "León and the beginnings of the Spanish Romanesque", en O’Neill, J. P. (ed.), The Art of Medieval Spain, a. d. 500-1200, pp. 167-173. Metropolitan Museum of Art, New York.

Williams, J. 1997, “León: la iconografía de la capital”, en El Reino de León en la Alta Edad Media, vol. IX, pp. 9-37. Centro de Estudios e Investigación "San Isidoro", León.

Williams, J. 2003: “Generationes Abrahae: Iconografía de la Reconquista en León”, en Sánchez Ameijeiras, R. y Senra Gabriel y Galán, J. L. (coords.): El Tímpano Románico. Imágenes, Estructuras y Audiencias, pp. 155-180. Xunta de Galicia, Santiago de Compostela.

Williams, J. 2008: "Un plano inédito de 1971 muestra los cimientos de San Isidoro", Diario de León, Sábado, 12 de Abril del 2008, pp. 58-59 (artículo redactado por C. Fanjul).

Williams, J. 2011: "San Isidoro exposed: the vicissitudes of research in Romanesque art", Journal of Medieval Iberian Studies, 3/1, pp. 93-116.

Yarza, J. 1979: Arte y Arquitectura en España, 500-1250. Ediciones Cátedra, Madrid. 